\title{
LIETUVOS KARIUOMENĖS KARO POLICIJA 1919-1940 METAIS
}

\author{
Lina Kasparaitè-Balaišè \\ Vytauto Didžiojo karo muziejus
}

\section{IVADAS}

Atkurtos Lietuvos Respublikos valstybingumo pradžioje krašto apsaugos sistemoje pradejo veikti karinès teisètvarkos institucija - karo policija, kaip kariuomenès dalis, vykdanti viešosios tvarkos pažeidimų ir nusikaltimų prevenciją, dalyvaujanti juos atskleidžiant ir iš dalies tiriant. Karo policija palaikè tvarką ir drausmę kariuomenès teritorijoje ir viešosiose vietose. Karo policijos tarnyba buvo siejama ne tik su karinès drausmès pažeidimų ir nusikaltimų kariuomenejje prevencija, apsaugos tarnybų vykdymu bei pasirengimu operatyviai reaguoti nenumatytomis aplinkybėmis. Karo policininkai vykdè ir kitas nustatytas funkcijas, turejjo specialų statusą, apibrèžiantị jų teises, pareigas ir atsakomybę $e^{1}$.

Kuriant Lietuvos Respublikos karines pajègas ir integruojant jas ị krašto apsaugos sistemą, karinė vadovybè, plètodama savo veiklą laikinojoje Lietuvos sostinejje, susidūrẻ su problema - nebuvo institucijos, kuri užtikrintų karinę teisètvarką šiame svarbiame valstybės taške. Šią problemą buvo imtasi spręsti įsteigiant Karo policijos mokyklą. Ji renge karo policininkus ir kartu buvo institucija, kuri igyvendino karinę teisètvarką. Tačiau karo policininkai tuo neapsiribojo. Svarbu pažymèti, kad Karo policijos mokykla ne tik rengė karo policininkus, bet ir vykdè karo policijos užduotis. Iš čia ir kyla šio tyrimo probleminiai klausimai: kaip ir kokiu tikslu buvo suformuota karo policija ir Karo policijos mokykla? Kokios buvo mokyklos ypatybès, lėmusios specifinę šios karinès dalies struktūrą ir funkcionavimą, kompetencija ir uždaviniai? Ar karo policija tinkamai užtikrino karinę teisètvarką ir kitas jai patikètas tarnybines pareigas?

\footnotetext{
${ }^{1}$ Enciklopedinis karybos žodynas, red. Z. Kulys, Vilnius, 2008, p. 256.
} 
Iki šių dienų istorijos tyrèjai išsamiai nenagrinèjo Lietuvos Respublikos karo policijos istorijos, jos funkcionavimo aplinkybių, veiklos. Istorikų darbuose apie karo policiją tik užsimenama bendrame kitų tyrimų kontekste, tačiau atskirų publikacijų minèta tematika nèra. Nagrinèjama tematika parašytas vienintelis informacinis straipsnis ${ }^{2}$ Karo policijos 90 ies metų sukakčiai paminèti, daugiau skirtas trumpai jos istorijai pristatyti. Minètame straipsnyje pateikta enciklopedinio pobūdžio informacija: trumpai pristatytos svarbiausios karo policijos organizavimo datos, užsiminta apie jos organizacinę struktūrą ir funkcijas, paminèta keletas ikonografinių šaltinių. Ko gero, daugiausiai duomenų pasirinkta tematika pateikta istoriko Andriejaus Stoliarovo straipsnyje Lietuvos Respublikos karinè teisèsauga: Armijos teismas 1919-1922 metais ${ }^{3}$. Autorius, nagrinèdamas karinès teisėsaugos institucijų veiklos istoriją, aprašo ir karo policijos, kaip vienos iš krašto apsaugos sistemoje veikusių teisèsaugos institucijų, funkcijas, kurios buvo susijusios su karinès teisèsaugos igyvendinimu. Šioje publikacijoje pateikiama šiek tiek faktinès informacijos apie pirmuosius karo policijos formavimo procesus, organizacinę struktūrą, pristatomi mokymo programų bendrieji aspektai ir karo policijos tarnybinè veikla.

Vertingos informacijos pateikta buvusio Lietuvos Respublikos kariuomenès karininko Vytenio Statkaus knygoje Lietuvos ginkluotos pajègos 1918-19404. Autorius, remdamasis karo policijoje tarnavusių karininkų atsiminimais ir tarpukario periodineje spaudoje publikuotais straipsniais, pateikia duomenų apie Karo policijos mokyklos (toliau - KPM) organizacinę struktūrą, karių aprangą ir tarnybas.

Istorikas Jonas Aničas biografineje apybraižoje Pulkininkas Jurgis Bobelis (1895-1954)5 pažymi Karo (lauko) milicijos kuopos vaidmeni antivalstybinių jègų likvidavimo operacijose, užsimena apie karo policijos funkcionavimą, organizacinę struktūrą, karo policininkų tarnybas ir dalyvavimą metinèse Kauno miesto ir apskrities komendantūros šventėse.

\footnotetext{
${ }^{2}$ Karo policijos informacija, Lietuvos kariuomenès Karo policija švenčia 90 metų jubiliejų, Krašto apsauga, 2009, Nr. 5, p. 10.

${ }^{3}$ A. Stoliarovas, Lietuvos Respublikos karinè teisèsauga: Armijos teismas 1919-1922 metais, Karo archyvas, 2010, t. 25, p. 176-183.

${ }^{4}$ V. Statkus, Lietuvos ginkluotos pajégos 1918-1940, Čikaga, 1986, p. 423-424.

${ }^{5}$ J. Aničas, Pulkininkas Jurgis Bobelis (1895-1954), Vilnius, 2004, p. 24, 118, 120, 132, 137.
} 
Istorikas Vytautas Lesčius pateikia daugiau faktinès informacijos apie Karo policijos organizavimą. Autorius monografijoje Lietuvos kariuomené 1918-1920 ir straipsnyje Lietuvos miestu ir apskričiu karo komendantūros 1918-1920 metais $^{7}$ pateikia karo policijos, kaip tarnybos, organizavimo aspektus. Kitame savo straipsnyje - Lietuvos kariuomenés organizavimo, dislokavimo ir ginkluotes pokyčiai 1938-1940 m. ${ }^{8}$ - bendrame kariuomenès dalinių gynybinių funkcijų kontekste užsimena apie KPM prieššarvinių kuopų priklausomybę.

Panašią faktinę medžiagą pateikia ir istorikas Deimantas Palkevičius straipsnyje Karinès komendantūros 1918-1920 m. ${ }^{9}$ Autorius, nagrinèdamas Kauno miesto komendantūros kūrimosi aspektus, išskiria ir pagrindines karo policijos organizavimo datas. Reikia pažymėti, kad šiame straipsnyje kiek netiksliai pateikiamas faktas apie Karo (lauko) milicijos kuopos panaikinimą 1919 m. liepos 18 d., kadangi ši kuopa nebuvo panaikinta, o tik performuota ir pakeistas pavadinimas.

Monografijoje Lietuviu karyba ir ginkluote (iki $1940 \mathrm{~m}$.) $)^{10}$ istorikas Algimantas Liekis aprašo apytikslę karo policijos dislokacijos vietą, užsimena apie jos funkcijas ir pagrindinius karo policininkų uždavinius. Faktinès informacijos apie karo policininkų dalyvavimą $1923 \mathrm{~m}$. sausio $10-15$ d. Klaipèdos krašto sukilime pateikia istorikai Petronèlė Žostautaitè studijoje Klaipédos kraštas 1923-193911 ir Vygantas Vareikis monografijoje Klaipéda XX amžiuje ${ }^{12}$. Autoriai daugiau nagrinèjo minėto sukilimo organizacinę veiklą, tačiau šiame kontekste aptarè ir sukilime dalyvavusių reguliariosios kariuomenès dalinių sudètị, paminejjo žuvusius karius.

Istorikas Jonas Švoba knygoje Seimine ir prezidentine Lietuva ${ }^{13}$ gana

\footnotetext{
${ }^{6}$ V. Lesčius, Lietuvos kariuomene 1918-1920, Vilnius, 1998, p. 110, 113-114.

${ }^{7}$ V. Lesčius, Lietuvos miestų ir apskričių karo komendantūros 1918-1920 metais, Karo archyvas, 2001, t. 15, p. 124.

${ }^{8}$ V. Lesčius, Lietuvos kariuomenès organizavimo, dislokavimo ir ginkluotès pokyčiai 1938-1940 m., Karo archyvas, 2009, t. 24, p. 152.

${ }^{9}$ D. Palkevičius, Karinès komendantūros 1918-1920 m., Lietuvos archyvai, 1999, t. 12, p. 68.

${ }^{10}$ A. Liekis, Lietuviu karyba ir ginkluotè (iki 1940 m.), Vilnius, 2002, p. 514.

${ }^{11}$ P. Žostautaite, Klaipedos kraštas 1923-1939, Vilnius, 1992, p. 29.

${ }^{12}$ V. Vareikis, Klaipèda XX amžiuje, Klaipèda, 1993, p. 25-26.

${ }^{13}$ J. Švoba, Seimine ir prezidentiné Lietuva, Vilnius, 1990, p. 160.
} 
išsamiai aptaria 1926 m. gruodžio 17 d. perversmą ir jo kontekste pažymi, kad KPM kariai dalyvavo pasipriešinime šiems įvykiams. Panašiai, tik kiek siauriau, apie tai rašo ir istorikas Ričardas Čepas monografijoje Plečkaitininkai ${ }^{14}$. Istorikas Arvydas Anušauskas ir žurnaliste Gražina Sviderskytė studijoje XX amžiaus slaptieji archyvai ${ }^{15}$ pateikia plačiai istoriografijoje nušviesto ịvykio, žinomo Klaipėdos krašto nacių teismo pavadinimu, eigą. Autoriai, aprašydami teismo proceso aplinkybes, užsimena, kad teisiamuosius saugojo karo policininkai. Apžvelgus nagrinèjamojo laikotarpio spaudos leidinius ${ }^{16}$, kuriuose rašoma apie ši teismą, nerasta duomenų, patvirtinančių karo policininkų apsaugos faktą. Spaudoje pažymima, kad teisiamuosius saugojo kariuomenès atstovai ir policijos pareigūnai, o atskirai apie karo policininkus neužsimenama. Tenka konstatuoti, kad ì klausimą, ar karo policininkai saugojo Klaipėdos krašto nacių teismo teisiamuosius, liko neatsakyta.

Dèl pasirinktos nagrinèti tematikos mokslo darbų stokos reikèjo dèmesị sutelkti ị šaltinius. Juos galima suskirstyti ị kelias grupes. Didžiausią ir svarbiausią tyrimo metu naudotą jų dalị sudarè archyviniai šaltiniai, saugomi Lietuvos centriniame valstybès archyve (toliau - LCVA). Ypatingas dèmesys buvo skirtas fondui nr. 1471. Čia pavyko rasti daugiausiai medžiagos, kuri padejjo išnagrinèti pagrindinius Karo policijos mokyklos istorijos tarpsnius, susijusius su mokyklos funkcionavimu ir karių tarnyba. Dokumentų, ịvairiai atspindinčių karo policijos veiklą buvo rasta Kauno komendantūros fonde nr. 1126. Fonde nr. 930 pavyko rasti dokumentą, iš kurio galima spręsti apie mokyklos kariams priskirtas funkcijas ir reikšmę karinio puolimo metu. Reikia pažymèti, kad archyviniuose dokumentuose pateikta informacija yra fragmentiška ir daugiausia atspindi $\mathrm{XX}$ a. 3-iojo pirmosios pusès ir 4-ojo dešimtmečių padètį. Informacijos apie kitą laikotarpi yra labai mažai.

Archyvinių dokumentų medžiagą papilde įvairūs publikuoti šaltiniai, t. y. periodinè spauda, leidiniai. Daugiausia informacijos apie KPM karių

\footnotetext{
${ }^{14}$ R. Čepas, Plečkaitininkai, Vilnius, 2000, p. 19.

${ }^{15}$ A. Anušauskas, G. Sviderskyte, XX amžiaus slaptieji archyvai, Vilnius, 2008, p. 46.

${ }^{16}$ Didžioji Neumano ir Zaso byla jau prasidejo, Lietuvos keleivis, 1934, Nr. 290, p. 1; Klaipėdos hitlerininkų 50-oji teismo diena, ten pat, 1935, Nr. 49, p. 2; Valstybès išdavimo byla prasidejo, Karys, 1934, Nr. 51-52, p. 1076-1078.
} 
laisvalaikio leidimo būdus ir dalyvavimą visuomeniniame gyvenime rasta periodiniame leidinyje $\operatorname{Karys}^{17}$, dalis duomenų apie KPM priešgaisrinès apsaugos tarnybą - periodiniuose leidiniuose Lietuvos gaisrininkas ${ }^{18}$ ir Ugniagesys, o ịvairaus pobūdžio duomenų, kurie padejo papildyti informaciją nagrinejjama tema, - periodiniuose leidiniuose $\operatorname{Kardas}^{19}$, Policija ${ }^{20}$, Karo archyvas ${ }^{21}$ ir Mūsų žinynas ${ }^{22}$.

Reikia paminèti dar vieną publikuotų šaltinių grupę, kurią sudare ịsakymų Lietuvos kariuomenei rinkiniai ${ }^{23}$ ir Kariuomenès vidaus tarnybos statutas $^{24}$. Jie padejo analizuojant ịvairius karo policijos istorijos periodus ir plačiau apžvelgti jos funkcionavimą bendrame kariuomenès kontekste. Isakymuose kariuomenei buvo rasta naudingos informacijos, kuri suteike galimybę papildyti žinias apie KPM struktūrines ir funkcines ypatybes ir karių veiklą. Kariuomenès vidaus tarnybos statutas buvo naudingas analizuojant nuobaudų sistemos taikymo mokyklos kariams galimybes.

Atskirą šaltinių grupę sudarė memuaristika ir informaciniai leidiniai. Vertingiausi - buvusio karo policininko Jono Demereckio atsiminimai ${ }^{25}$, padeję atskleisti įvairias dar Karo milicijos mokyklos (toliau - KMM) funkcionavimo ir karių tarnybos ypatybes. Atsiminimų autorius buvo vienas pirmųjų Karo milicijos mokykloje (1920 m.) tarnavusių policininkų, todèl šis veikalas tapo svarbiu tyrime naudotinu šaltiniu. Generalinio šta-

\footnotetext{
${ }^{17}$ Karys - periodinis leidinys, 1920-1945 m. leistas Lietuvos kariuomenès štabo Spaudos ir švietimo skyriaus.

${ }^{18}$ Lietuvos gaisrininkas - periodinis leidinys (profesinis laikraštis), leistas 1923-1932 m. Nuo 1933 m. jo pavadinimas - Ugniagesys.

${ }^{19}$ Kardas - periodinis Lietuvos kariuomenès karininkų leidinys, leistas 1925-1940 m.

${ }^{20}$ Policija - Vidaus reikalų ministerijos Piliečių apsaugos departamento periodinis leidinys, leistas 1924-1940 m.

${ }^{21}$ P. Gužas, Atsiminimai iš Kauno karo komendantūros darbų 1919 m. sausio-kovo mèn., Karo archyvas, 1925, t. 1, p. 192-204; K. Karpenka, Pirmieji Kauno miesto ir apskrities karo komendantūros gyvavimo metai, Karo archyvas, 1926, t. 3, p. 32-37.

${ }^{22}$ A. Zarinas, Kvota karo baudžiamajame procese, Mūsǔ žinynas, 1927, Nr. 36, p. 294.

${ }^{23}$ Isakymai kariuomenei nuo 1918 m. lapkričio 23 d. buvo vadinami ịsakymais Krašto apsaugos ministerijai, nuo 1919 m. birželio 5 d. - isakymais Lietuvos kariuomenei. Nuo 1924 m. sausio 1 d. iki 1927 m. sausio 1 d. - krašto apsaugos ministro įsakymais, nuo 1940 m. liepos 6 d. - isakymais Liaudies kariuomenei.

${ }^{24}$ Vyriausiojo štabo Spaudos ir švietimo skyrius, Vidaus tarnybos statutas, Kaunas, 1931.

${ }^{25}$ J. Demereckis, Savanorio ir kontržvalgybininko atsiminimai, Čikaga, 1979.
} 
bo pulkininko ir valstybès veikejjo Kazio Škirpos atsiminimai ${ }^{26}$ reikšmingi vertinant KPM karių vaidmenị 1926 m. gruodžio 17 d. perversmo įvykių kontekste. Plk. Jurgio Bobelio atsiminimai ${ }^{27}$ buvo naudingi vertinant Karo (lauko) milicijos kuopą jos kūrimo pradžioje. Informacinio leidinio Lietuvos policija 1918-1928 ${ }^{28}$ duomenys padejo atskleisti Karo (lauko) milicijos kuopos organizavimo priežastis.

Šio tyrimo chronologinių ribų atskaitos taškas - 1919 m. kovo 15 d., kai buvo pradèti pirmieji Lietuvos Respublikos kariuomenès karo milicijos organizavimo darbai. Tyrimo laikotarpis užbaigiamas 1940 m. lapkričio $11 \mathrm{~d}$. ir sietinas su pirmąja sovietine okupacija, kai Karo policijos mokykla

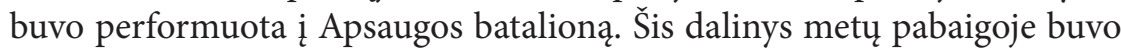
likviduotas, o kariai perkelti į Raudonosios armijos (toliau - RA) dalinius.

Šio straipsnio tikslas - išanalizuoti Lietuvos karo policijos istoriją.

\section{KARO POLICIJOS STRUKTŪRA IR FUNKCIONAVIMAS}

Karo (lauko) milicijos tarnyba buvo suformuota kovų dèl Lietuvos nepriklausomybės pradžioje. Ją performavus buvo įsteigta Karo (lauko) milicijos mokykla, nustatyta jos struktūra, personalo sudetis ir funkcijos, vidaus išskirtinès taisyklès, tvarka ir tarnybos. Karo policininkų rengimas vyko pagal specialias mokymo programas. Mokyklos kariai dejvejo uniformas su išskirtiniais ženklais, buvo gerai ginkluoti ir tinkamai pasirengę eiti karo policininkų pareigas.

\section{Karo policijos tarnybos ir mokyklos organizavimas}

1919 m. pradžioje Kauno miesto komendantūros kariai užtikrino viešąją tvarką visuomenejje ir kariuomenejje, ejjo ịvairaus pobūdžio tarnybas,

\footnotetext{
${ }^{26}$ K. Škirpa, Pakeliui su Mykolu Sleževičiumi, Mykolas Sleževičius, Čikaga, 1954.

27 Savanoris 1918-1920, red. S. Butkus, Kaunas, 1929.

${ }^{28}$ Lietuvos policija 1918-1928, red. I. Tomašauskas, Kaunas, 1930.
} 
neretai labiau susijusias su milicijos kompetencija ${ }^{29}$. Kariuomenè, kaip ir milicija, buvo tik pradejjusi organizacinị darbą - Kauno apskrities milicija pradejjo veikti $1918 \mathrm{~m}$. spalio pabaigoje ${ }^{30}$. Besikuriančios milicijos pirmieji tarnybos ménesiai buvo sunkūs - susidurta su ịvairiomis problemomis. Trūko kvalifikuotų tarnautojų, ginklų, transporto, uniformų ir ryšio priemonių. Stokojant lěšų, daugelyje vietų milicininkams net nebuvo mokamas atlyginimas. Dèl šių problemų organizaciniai darbai užtruko ${ }^{31}$. Nagrinèjamu laikotarpiu milicija dar nebuvo pajėgi užtikrinti tvarką Kauno mieste ir jo apylinkèse, todèl 1919 m. kovo 15 d. Kauno komendantas krn. Juozas Mikuckis prie komendantūros įsakè suformuoti Karo (lauko) miliciją, jos viršininku paskyrẻ krn. Joną Jočị, o jo padejjeju (kovo 25 d.) - krn. Joną Šalkauską. Kadangi milicija buvo kuriama prie Kauno miesto komendantūros, pastarosios kariai buvo skiriami ị formuojamą kuopą. Kovo 29 d. ì Karo (lauko) milicijos kuopą buvo paskirta 60 karių: iš 1-osios komendantūros kuopos - 15, iš 2-osios - 16, iš 3-iosios - 14, iš 4-osios - 11, iš mokomosios komandos -3 , iš žvalgų komandos $-1^{32}$. Šie kariai turẻjo būti aukšto ūgio, stambaus kūno sudejjimo ir tinkamo išsilavinimo (mokèti skaityti ir rašyti) ${ }^{33}$. Nuo balandžio $25 \mathrm{~d}$. kuopoje buvo sudarytas raitelių būrys, jo vadu paskirtas 1-ojo husarų eskadrono krn. Jonas Eidukaitis ${ }^{34}$. Tuo metu Karo (lauko) milicijos kuopos kariai dar buvo vadinami „karo žandarais“"35.

${ }^{29}$ Kauno karo komendantūra 1919-1929, red. P. Jurgelevičius, Kaunas, 1930, p. 41.

${ }^{30}$ Lietuvos policija 1918-1928, red. I. Tomašauskas, p. 36.

${ }^{31}$ Č. Mančinskas, Policija Lietuvoje 1918-1940 metais, Vilnius, 1998, p. 10.

${ }^{32} 1919$ m. balandžio 25 d. Kauno miesto komendanto įsakymas Nr. 107/2 komendantūrai, LCVA, f. 1126, ap. 4, b. 206, 1. 367-368.

${ }^{33}$ V. Lesčius, Lietuvos kariuomenè 1918-1920, p. 113.

${ }^{34} 1919$ m. gegužès 1 d. Kauno miesto komendanto įsakymas Nr. 113/3 komendantūrai, LCVA, f. 1126, ap. 4, b. 206, 1. 383.

35 Terminas „žandaras“ kilęs iš prancūzų kalbos gendarme. Lietuvoje pradètas vartoti carinès Rusijos imperijos laikotarpiu. Rusijoje pirmoji karinè žandarmerija buvo ịsteigta 1792 m. ir vadinama leibgvardija (rus. лейб-гвардия), nuo 1815 m. - žandarų puseskadronis (rus. жандармский полуэскадрон). Žandarmerija atliko karo policijos vaidmenį, palaike tvarką kariuomenejje. XIX a. 3-iajame dešimtmetyje buvo reorganizuota ir tapo svarbiausia kariuomenès dalimi, kovojančia su revoliuciniu judejimu. XIX a. antroje pusejje buvo 123 žandarų komandos, dalis jų veikè ir Lietuvoje. Žandarai kovojo su antivalstybiniu judejjimu, tardè, konvojavo nusikaltèlius, vykdè pabėgusių rekrūtų ir nusikaltèlių paiešką, šnipinèjo. Советская историческая энциклопедия, ред. Е. М. Жуков, Москва, 1964, т. 5, с. 526. 
Iš pradžių kuopos kariai daugiausia buvo užsièmę administraciniais komendantūros reikalais, neretai atlikdavo kratas, areštus ir kitas užduotis ${ }^{36}$, pavyzdžiui, Kauno apylinkėse dalyvavo Veliuonos operacijoje.

Birželio 17-18 d. Kauno miesto komendantūra gavo žinių, kad Veliuonoje vietos komitetas, vadovaujamas vokiečių, nuginklavo miliciją ir įvedè savo valdžią. Neramumams Veliuonoje numalšinti buvo išsiųsta Karo (lauko) milicijos kuopa. Tačiau ji, susidūrusi su vietos gyventojų ginkluotu pasipriešinimu, po keletą valandų trukusio susišaudymo buvo išsklaidyta. Po šios nesėkmès malšinti incidento atvyko krn. Jurgio Bobelio vadovaujama komendantūros mokomoji komanda ir greitai užgniaužè kilusius neramumus ${ }^{37}$.

Vertinant Karo (lauko) milicijos kuopos nesèkmę Veliuonoje pažymètina, kad kuopa nebuvo tinkamai parengta rimtiems ginkluotiems konfliktams malšinti - trūko specialių mokymų. Neretai pratybų metu pasitaikydavo nelaimingų atsitikimų, pavyzdžiui, kai per neatsargumą mirtinai buvo sužeidžiamas karys. Po tokių nelaimingų atsitikimų Kauno miesto komendantas ịsakydavo Karo (lauko) milicijos kuopai skirti daugiau dèmesio saugaus elgesio naudojantis šautuvu taisyklems ${ }^{38}$. Svarbesnèms operacijoms, susijusioms su antivalstybinemis jẻgomis (pvz., lenkų karinès organizacijos $\mathrm{POW}^{39}$ likvidavimu), vykdyti dažnai buvo skiriama Kauno komendantūros mokomoji komanda ${ }^{40}$. Karo (lauko) milicijos kuopa daugiausia veikè mieste.

1919 m. viduryje Kauno miesto komendantūroje ịvyko reorganizacija. Liepos $18 \mathrm{~d}$. iš mokomosios komandos buvo suformuota Miesto kuopa. Tuo metu vietos milicija jau buvo organizuota ir galejo tinkamai užtikrinti viešąją tvarką ir saugumą ${ }^{41}$, todèl liepos $18 \mathrm{~d}$. Karo (lauko) milicijos kuopa buvo performuota ir pavadinta Apskrities kuopa, jos vadu liko

\footnotetext{
${ }^{36}$ Savanoris 1918-1920, red. S. Butkus, p. 174.

37 Ten pat, p. 174.

${ }^{38} 1919$ m. gegužès 15 d. Kauno miesto komendanto įsakymas Nr. 227/6 komendantūrai, LCVA, f. 1126, ap. 4, b. 206, 1. 433ap.

${ }^{39}$ POW - lenk. Polska organizacja wojskowa - lenkų karinė organizacija.

${ }^{40}$ Kauno karo komendantūra 1919-1929, red. P. Jurgelevičius, p. 21-29.

${ }^{41}$ V. Lesčius, Lietuvos kariuomené 1918-1920, p. 113.
} 


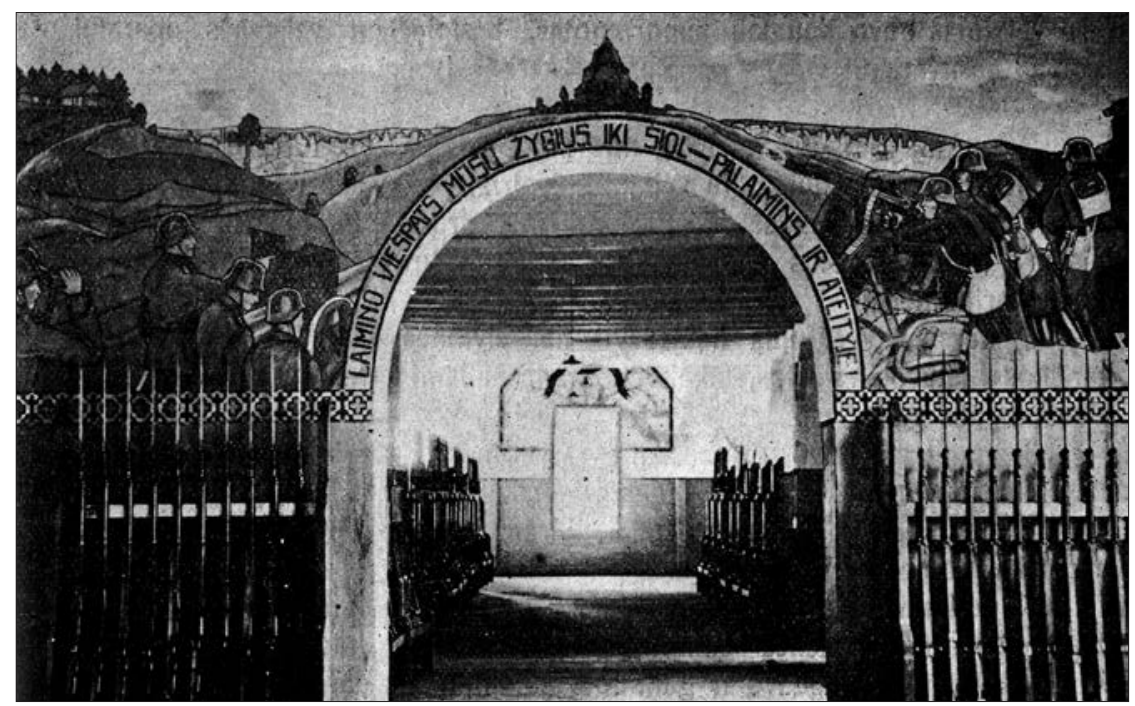

Karo policijos mokyklos kareivinių vidus (Kauno karo komendantūra 1919-1929, red. P. Jurgelevičius, p. 53)

krn. J. Jočys ${ }^{42}$. Ši kuopa turejjo sargybos postus keturiose miesto vietose: prie Kauno komendantūros rūmų buvo paskirtas vyresnysis ir dvylika kareivių ${ }^{43}$, vienas kareivis - prie viešbučio „Metropolis“, prie Kauno igulos areštinès sargybą ejjo vyresnysis ir 17 kareivių, prie Armijos teismo - du kareiviai ${ }^{44}$.

1919 m. pabaigoje buvo pradèta kurti Karo (lauko) milicijos mokykla. Tų pačių metų gruodžio $1 \mathrm{~d}$. Kauno karo komendanto krn. J. Mikuckio isakymu buvo pradèta formuoti Karo (lauko) milicijos komanda, o jos vadu paskirtas ltn. Kostas Rudaitis-Rudavičius ${ }^{45} .1920$ m. sausio 1 d. Karo

\footnotetext{
${ }^{42} 1919$ m. rugpjūčio 2 d. Kauno miesto komendanto įsakymas Nr. 206/3 komendantūrai, LCVA, f. 1126, ap. 4, b. 210, 1. 75 .

${ }^{43}$ Ten pat.

${ }^{44} 1919$ m. gruodžio 19 d. Kauno karo komendanto įsakymas Nr. 346/1 komendantūrai, ten pat, b. 210, 1. 387.

${ }^{45}$ K. Karpenka, Pirmieji Kauno miesto ir apskrities karo komendantūros gyvavimo metai, Karo archyvas, 1926, t. 3, p. 37.
} 
(lauko) milicijos komandos pagrindu buvo įsteigta Karo (lauko) milicijos mokykla ${ }^{46}$. Mokyklos viršininku tapo ltn. K. Rudaitis-Rudavičius ${ }^{47}$. 1924 m. spalio 1 d. krašto apsaugos ministras plk. Teodoras Daukantas įsakè Karo milicijos mokyklą pervardinti ị Karo policijos mokyklą ${ }^{48}$. Nuo 1919 m. gruodžio mokykla buvo įsikūrusi Kęstučio g. 34, 35 ir 37, o rikiuotès pratybos („pratimai“) vykdavo Žaliakalnyje, netoli Adomo Mickevičiaus slènio, kareiviai buvo apgyvendinti Maironio gatveje. 1920 m. rugsèjo mèn. mokykla persikèlè į Gedimino g. $29^{49}$. Vèliau mokykla ir kareivinès buvo perkeltos ị 13-ąsias Šančių kareivines, o 1922 m. gegužès 19 d. - ị Žaliakalnị, kareivines nr. 40 $0^{50}$, kurios buvo Aukštaičių, Kipro Petrausko, Martyno Jankaus ir Vinco Kudirkos gatvių sankirtoje ${ }^{51}$. Čia veikè mokykla ir kareivinès iki mokyklos likvidavimo. Šiuo metu buvusioje Karo policijos mokyklos kareivinių teritorijoje yra Kauno medicinos universiteto Medicinos fakulteto Kalbų ir edukacijos katedra, sporto salè ir studentų bendrabučiai. Nagrinejjamu laikotarpiu mokykla buvo issikūrusi penkiuose pastatuose. Pvz., pastate nr. 52 buvo mokyklos viršininko kabinetas, klasès, kareivių patalpos, prausykla ir valgykla, pastate nr. 57, dar vadinamame puskarininkių pastatu, - puskarininkių ir viršilų bendrabutis, skaitykla, parduotuve, kirpykla. Atskirame pastate nr. 54 buvo aprangos, ginklų ir maisto sandèliai. Keletas patalpų pastate nr. 58 buvo skirtos daiktų sandèliams, čia taip pat buvo ịkurtos papildomos karių

\footnotetext{
${ }^{46}$ Archyviniuose dokumentuose, datuotinuose iki 1922 m., mokyklos pavadinimas ivvairuoja: sudarytas ir su žodžiu „lauko“ ir be jo. Nuo 1922 m. dokumentuose jau vartotas Karo milicijos mokyklos pavadinimas.

${ }^{47} 1920$ m. vasario 3 d. Kauno karo komendanto įsakymas Nr. 34/2 komendantūrai, LCVA, f. 1126 , ap. 4, b. $219,1.84$.

${ }^{48}$ Isakymas kariuomenei Nr. 103/1, 1924 m. spalio $10 \mathrm{~d}$.

491920 m. rugsèjo 28 d. Kauno karo komendanto įsakymas Nr. 272/3 komendantūrai, LCVA, f. 1126, ap. 4, b. 217, 1. 28; J. Demereckis, Savanorio ir kontržvalgybininko atsiminimai, p. 36; A. Stoliarovas, Lietuvos Respublikos karinè teisèsauga: Armijos teismas 1919-1922 metais, Karo archyvas, 2010, t. 25, p. 178.

${ }^{50} 1922$ m. gegužès 19 d. Karo milicijos mokyklos viršininko pareiškimas Kauno karo komendantui dèl Karo milicijos mokyklos persikèlimo ị Žaliakalnio kareivines, LCVA, f. 1126, ap. 2, b. 222, 1. 45ap.

51 A. Stoliarovas, Lietuvos Respublikos karinè teisèsauga: Armijos teismas 1919-1922 metais, Karo archyvas, 2010, t. 25, p. 178.
} 
patalpos, stalių, siuvejų, batsiuvių dirbtuvès ir sporto salè $\dot{e}^{52}$. Karo policijos mokyklos kareivinès buvo tvarkingos, pastatų vidų puošè trispalvès ${ }^{53}$, šūkiai ir karinès tematikos piešiniai ant sienų.

Karo komendanto patikrinimo metu dèl kareivinių ir šio rajono nesulaukta vadovybès priekaištų, nes visur buvo švaru ir tvarkinga ${ }^{54}$. Neatsitiktinai KPM buvo ịsteigta Kauno mieste - čia buvo dislokuota daug Lietuvos kariuomenès dalinių, įsikūrę pagrindiniai valdžios organai ir institucijos.

KPM buvo atskirosios pèstininkų kuopos sudeties. Ją sudarè dvi dalys: mokomoji ir karo policininkų 5 . Mokomąją dali sudare 1-asis, 2-asis ir 3-iasis būriai ${ }^{56}$, nuo $1931 \mathrm{~m}$. mokykloje pradejjo veikti ugniagesių koman$\mathrm{da}^{57}$, kurios tikslas buvo priešgaisrinè dalinių apsauga ir pagalba miesto ugniagesių komandoms didelio gaisro atveju, kareivių mokymas priešgaisrinès saugos, kad po privalomosios tarnybos kariams būtų suteikta galimybė dirbti valstybinėse priešgaisrinèse gelbejjimo tarnybose ${ }^{58}$. Mokykla buvo suskirstyta ị dvi kuopas dèl padidejusio karių skaičiaus. 1937 m. 1-ąją kuopą sudarè 1-asis ir mokomasis, 2-ąją - 3-iasis, 4-asis ir karo policininkų būriai ${ }^{59} .1939$ m. sausio mèn. KPM sudètis dar kartą pakito, mokykla buvo pertvarkyta ị batalioną suformavus tris kuopas: 1-ąją ir 2-ąją prieššarvines apsaugos kuopas, pastarąją sudare karo policininkų ir pagalbiniai būriai ${ }^{60}$. Tuo metu mokykla pradèjo rengti ne tik karo polici-

521936 m. liepos 27 d. Aktas dèl Karo policijos mokyklos elektros energijos naudojimo patalpų apšvietimui, LCVA, f. 1471, ap. 1, b. 30, 1. 19-19ap.

${ }^{53}$ Kazlauskas, Tik ištižèliai bijo kariuomenèn stoti, Karys, 1926, Nr. 9, p. 82.

${ }^{54} 1929$ m. balandžio 24 d. Kauno igulos viršininko įsakymas Nr. 4/2 Kauno igulai, LCVA, f. 1126, ap. 2, b. 22, 1. 6 ap.

${ }^{55}$ V. Statkus, Lietuvos ginkluotos pajëgos 1918-1940 m., p. 423.

${ }^{56} 1920$ m. lapkričio 6 d. Kauno karo komendanto ísakymas Nr. 312/1 komendantūrai, $L C V A$, f. 1126, ap. 4, b. 25, 1. 15; 1920 m. lapkričio 3 d. Kauno karo komendanto ịsakymas Nr. 308/1 komendantūrai, ten pat, 1. 5; 1920 m. lapkričio 8 d. Kauno karo komendanto issakymas Nr. 313/1 komendantūrai, ten pat, 1. 18.

${ }^{57}$ Isakymas kariuomenei Nr. 8/4, $1931 \mathrm{~m}$. sausio $29 \mathrm{~d}$.

${ }^{58}$ Ten pat, Nr. 49/1-14, 1928 m. birželio 15 d.

$591937 \mathrm{~m}$. sausio $23 \mathrm{~d}$. Kauno miesto ir apskrities komendanto isakymas Nr. 23/3 komendantūrai, LCVA, f. 1471, ap. 1, b. 42, 1. 23.

${ }^{60} 1940$ m. liepos 18 d. Karo policijos mokyklos viršininko slaptas raportas Kauno kariniam viršininkui dèl mokyklos sudèties pertvarkymo, ten pat, f. 1126, ap. 4, b. 331, 1. 72. 
ninkus, bet ir prieššarvinès apsaugos ${ }^{61}$ pèstininkus.

Konstatuotina, kad Karo policijos mokyklos tikslas buvo rengti kvalifikuotus puskarininkius, kurie sugebėtu atlikti karo policininkų pareigas: palaikyti viešąją tvarką kariuomenejje ir visuomenejje, malšinti neramumus, vykdyti dezertyrų paiešką, palaikyti tvarką mobilizacijos metu, užtikrinti valstybės turto apsaugą, teikti pagalbą vietos policijai ${ }^{62}$, karo atveju sekti gyventojus, ittariamus nusikaltimais, ir apie tai pranešti policijai $^{63}$. Mokykla buvo sudedamoji kariuomenès dalis, todèl joje galiojo visi kariuomenès statutai ${ }^{64}$. Kandidatai tarnauti mokykloje buvo renkami iš nepriekaištingo elgesio, mokančių skaityti ir rašyti ir tarnavusių kariuomenèje ne daugiau kaip tris mėnesius pretendentų. Kariuomenejje atitarnavę daugiau nei tris mėnesius ir pareiškę norą tarnauti mokykloje, baigę ją, privalèjo savanoriškai atitarnauti karo policijoje tiek laiko, kiek buvo tarnavę prieš ịstodami ị KPM, neskaitant trijų mėnesių. Tiek laiko turèjo pakakti kokybiškam karo policininkų rengimui. Eilinių karių mokslas trukdavo devynis, puskarininkių ir viršilų - keturis mėnesius ${ }^{65}$.

Naujokų prièmimas ị mokyklą vykdavo du kartus per metus: gegužès ir lapkričio ménesiais ${ }^{66}$. Buvo priimama apie 100 naujokų ${ }^{67}$. Baigę keturių savaičių mokymo programą ir davę priesaiką kareiviai buvo perkeliami i mokomajji būrị, kuriame mokymas trukdavo dar šešis mènesius ${ }^{68}$. Jam pasibaigus, kareivių žinias tikrindavo ir vertindavo pagal penkiabalę (vèliau - dešimtbalę) vertinimo sistemą vietos kariuomenès brigados vado

\footnotetext{
${ }^{61}$ Prieššarvinè apsauga - specialios priemonès ir kovos veiksmai priešo tankų ir šarvuotųjų kovos mašinų atakoms atremti ir jiems naikinti, Enciklopedinis karybos žodynas, red. Z. Kulys, p. 167.

621920 m. kovo 20 d. Kauno karo komendanto pareiškimas krašto apsaugos ministrui dèl Karo milicijos mokyklos paskirties, ten pat, ap. 2, b. 129, 1. 30.

${ }^{63} 1922$ m. Karo milicijos mokyklos dèsniai, ten pat, b. 222, 1. 15.

${ }^{64}$ Issakymas kariuomenei Nr. 356/6, 1920 m. birželio $9 \mathrm{~d}$.

${ }^{65} 1922$ m. Karo milicijos mokyklos dèsniai, LCVA, f. 1126, ap. 2, b. 222, 1. 15.

${ }^{66}$ Karo policijos mokyklos 1938 m. gegužès 1d. kareivių šaukimo sąrašas, ten pat, f. 1471, ap. 1, b. 45, 1. 11; Karo policijos mokyklos 1938 m. lapkričio 1 d. kareivių šaukimo sąrašas, ten pat, 1. 17.

${ }^{67}$ V. Statkus, Lietuvos ginkluotos pajégos 1918-1940 m., p. 423.

${ }^{68} 1939$ m. kovo 29 d. Karo policijos mokyklos viršininko raportas Kauno miesto ir apskrities komendantui dèl mokomųjų programų tobulinimo, LCVA, f. 1471, ap. 1, b. 10, 1. 123.
} 
sudaryta komisija. Kareiviai, surinkę ne mažiau kaip keturis balus, „pirmos rūšies gabumų", tarnaudavo kaip jaunesnieji puskarininkiai, surinkę mažiau - „antros rūšies gabumų“ - eiliniais. Nuolatiniai karo policininkai buvo renkami tik iš baigusiųjų mokomojo būrio programą ${ }^{69}$. Kareiviai galèjo gauti aukštesnị laipsnị (vyresniojo puskarininkio ir viršilos) atitarnavę keturis ménesius ir tik tada, jei būdavo laisvų etatų ${ }^{70}$. Be to, jie turèjo nepriekaištingai elgtis, gerai atlikti tarnybines pareigas ${ }^{71}$. Baigę Karo policijos mokyklą kariai galejjo būti perkelti ị kitas kariuomenès dalis tarnauti kaip netinkantys karo policininkų tarnybai ${ }^{72}$. Mokykla karo policininkais skirdavo geriausius karius. Dažniausiai jie buvo perkeliami i geležinkelių policiją, kur labiausiai buvo laukiami ir kur jiems buvo teikiama pirmenybé $\dot{j}^{73}$. Toliau tarnauti kariai buvo siunčiami i karo kalejimą ${ }^{74}$. Baigę tarnybą kariuomenèje, jie galèjo tarnauti viešojoje policijoje $e^{75}$, nes karo policininko tarnyba buvo laikoma prioritetine, o baigusieji mokyklą jau buvo susipažinę su teisès ir valstybės valdymo dalykais, policijos tarnyba.

Reikia paminèti, kad 1924 m. Kaune (nedidelis būrys buvo suformuotas ir Zarasuose) karo policijos pagrindu suformuotą raitąji policijos būrị, dar kitaip vadinamą policijos rezervu prie vietos policijos. Vidaus reikalų ministerijai pavaldaus rezervo pagrindinè paskirtis buvo padèti policijai palaikyti tvarką: išsklaidyti draudžiamus susibūrimus, demonstracijas, sustabdyti riaušes, kovoti su ginkluotais užpuolimais, padeti viešajai policijai stichinių nelaimių metu palaikyti viešąją tvarką ${ }^{76}$. Raitojo policijos

${ }^{69} 1922$ m. Karo milicijos mokyklos dèsniai, ten pat, f. 1126, ap. 2, b. 222, 1. 15ap.; A. Stoliarovas, Lietuvos Respublikos karinè teisèsauga: Armijos teismas 1919-1922 metais, Karo archyvas, 2010, t. 25, p. 180.

${ }^{70}$ Isakymas kariuomenei Nr. 356/6, 1920 m. birželio 9 d.

${ }^{71} 1935$ m. lapkričio 22 d. Kauno miesto ir apskrities komendanto issakymas Nr. 329/3 komendantūrai, LCVA, f. 1471, ap. 1, b. 26, 1. 336.

${ }^{72} 1922$ m. Karo milicijos mokyklos desniai, ten pat, f. 1126, ap. 2, b. 222, 1. 15 ap.

${ }^{73} 1922 \mathrm{~m}$. žandarų puskarininkių prièmimo, paskyrimo ị vietas, atleidimo ir baudimo taisyklès, ten pat, f. 1471, ap. 1, b. 1, 1. 42.

741937 m. liepos 26 d. Kauno miesto ir apskrities komendanto issakymas Nr. 208/3 komendantūrai, ten pat, b. 42, 1. 211.

751939 m. vasario 8 d. Kauno apskrities policijos vado raštas Karo policijos mokyklos viršininkui dèl buvusio karo policininko charakteristikos, ten pat, b. 93, 1. 71.

${ }^{76}$ Č. Mančinskas, Policija Lietuvoje 1918-1940 metais, p. 34. 
rezervo paskirtis atitiko karo policijos paskirti - talkinti viešajai policijai. I rezervą buvo priimami tik lietuviai, atlikę karo prievolę, stambaus kūno sudejjimo, aukšto ūgio (ne žemesni kaip 1,72 m), nevedę, 21-28 metų, mokantys skaityti ir rašyti, pavyzdingo elgesio ${ }^{77}$. Buvo reikalaujama, kad priimami kandidatai i policijos rezervą kariuomeneje būtų tarnavę kavalerijos arba raitosios artilerijos dalyse ${ }^{78}$, kad mokètų valdyti žirgą. Atrankos kriterijai beveik nesiskyrė nuo karo policijos reikalavimų, išskyrus tai, kad ì pastarąąą buvo priimami ir vedę vyrai, naujokai arba atliekantys karo prievolę, kuriems nebuvo griežto amžiaus cenzo. Visi kiti kriterijai buvo identiški. Pagrindinis reikalavimas raitajam policijos rezervui - visada būti pasirengusiam, o prireikus kuo skubiau atvykti į nurodytą vietą, operatyviai reaguoti, sumaniai ir tiksliai veikti. Rezervas turejo laikytis bendrųjų policijos ịstatymų ir karinès drausmès ${ }^{79}$. Tam tikromis dienomis jiems buvo dėstoma teorinè medžiaga, paskui derinama su praktine tarnyba. Išèję parengiamąji kursą kandidatai ị policijos rezervą laikè teorinių ir praktinių dalykų egzaminus. Tvarkai mieste palaikyti kiekvieną dieną iš policijos rezervo buvo skiriami patruliai. Rezervo policininkai buvo apgyvendinti bendrabučiuose, kuriuose laisvu nuo tarnybos metu galejjo priimti svečius (tiesa, tai buvo griežtai reglamentuota taisyklèmis), tam tikram laikui išleidžiami i miestą, prieš tai atlikus tvarkos patikrą. Jiems buvo draudžiama lankytis alkoholiu prekiaujančiose miesto kavinèse ir restoranuose, kalbètis su įtartinais asmenimis, ne laiku grịžti ị bendrabutį. Už nusižengimus tvarkai policininkai buvo baudžiami drausminėmis nuobaudomis. Griežta karinè drausmè buvo privaloma ${ }^{80}$. Pažymètina, kad rezervo policininko aprūpinimas buvo dalinis. Paskirti čia tarnauti turèjo turèti savo patalynę, marškinius, pagrindinius asmeninius reikmenis ir lěšų uniformai įsigyti ${ }^{81}$. Galima teigti, kad policijos rezervo formavimo, drausmès pagrindai ir prièmimo ị rezervą atrankos

\footnotetext{
${ }^{77}$ Raitojo policijos rezervo vidaus tarnybos statutas, Policija, 1929, Nr. 13, p. 243.

${ }^{78} 1939$ m. policijos vadovybès reikalavimai priimant ị policijos rezervą, LCVA, f. 1471, ap. 1, b. 30, 1. 171 .

${ }^{79}$ Raitojo policijos rezervo vidaus tarnybos statutas, Policija, 1929, Nr. 13, p. 243.

${ }^{80}$ Ten pat, p. 243-245.

${ }^{81} 1939 \mathrm{~m}$. policijos vadovybès reikalavimai priimant ị policijos rezervą, LCVA, f. 1471, ap. 1, b. 30, 1. 171 .
} 
kriterijai atitiko karo policijos formavimo pagrindus. Griežtos vidaus tvarkos taisyklès ir reikalavimai buvo kuriami specialiai ypatingajam policijos daliniui. Griežtomis taisyklèmis ir tvarka grindžiant tarnybą buvo siekiama turèti sutelktas, visada pasirengusias reaguoti policijos pajėgas.

Apibendrinant karo policijos organizavimo nagrinejamu laikotarpiu ypatumus pasakytina, kad 1919 m. pavasari pradeta formuoti Karo (lauko) milicijos kuopa buvo pagalbinè vietos milicijos jèga, Karo (lauko) milicijos mokyklos, rengusios profesionalius karo milicijos (policijos) tarnautojus, pagrindas. Karo policijos mokykla buvo tiesiogiai pavaldi Kauno komendantūrai, jos dislokacijos vieta buvo parinkta dèl šio miesto strateginès svarbos. Mokyklos struktūros kaita buvo siejama su karių skaičiaus didejjimu ir funkcijų plètra. Mokyklos funkcijos buvo ne tik profesionalių karo policininkų rengimas, bet ir jų tarnybos organizavimas, o ypač karinès teisètvarkos ir tvarkos užtikrinimas, todèl ị ją būsimi karo policininkai buvo renkami pagal specialius kriterijus.

\section{Mokyklos personalo sudėtis}

Karo policijos mokykla buvo specifinè krašto apsaugos sistemos institucija. Jos personalą sudarẻ viršininkas, kuopų ir būrių vadai, kuopininkai, būrininkai, ginklininkai, raštininkai, ūkio dalies prižiūrètojai, paramedikai ${ }^{82}$, žirgų prižiūrètojai, siuvèjai, batsiuviai, virèjai ${ }^{83}$ ir kirpejjai. Pirmasis KPM viršininkas leitenantas K. Rudaitis-Rudavičius šias pareigas ejjo iki $1924 \mathrm{~m}$. pradžios, o nuo $1921 \mathrm{~m}$. liepos $1 \mathrm{~d}$. - taip pat ir 1-osios kuopos viršininko pareigas. 1926 m. pabaigoje ltn. K. Rudaitis-Rudavičius $^{84}$ buvo perkeltas ị Telšių apskrities komendantūrą, vèliau paskirtas

\footnotetext{
${ }^{82}$ Paramedikas - asmuo, išèjęs bazinį kario kursą (arba atlikęs privalomąją pradinę karo tarnybą) ir baigęs specialųji medicinos kursą, arba medicinos sesuo, felčeris, sanitaras, laborantas. Žr.: Enciklopedinis karybos žodynas, red. Z. Kulys, p. 421.

831920 m. Karo lauko milicijos mokyklos etatai, ten pat, f. 1126, ap. 2, b. 129, 1. 33; A. Stoliarovas, Lietuvos Respublikos karinè teisèsauga: Armijos teismas 1919-1922 metais, Karo archyvas, 2010, t. 25, p. 181.

${ }^{84}$ Kpt. K. Rudaitis-Rudavičius, eidamas Varnių koncentracijos stovyklos komendanto pareigas, pasisavino valstybès lèšų, nevengè imti kyšių. 1932 m. už piktnaudžiavimą tarnybine padètimi buvo atleistas iš pareigų ir patrauktas baudžiamojon atsakomybèn.
} 
Varnių koncentracijos stovyklos komendantu ${ }^{85}$. Po ltn. K. Rudaičio-Rudavičiaus KPM viršininko pareigas èjo vyr. ltn. Liudvikas (Liudas) Kaufmanas $^{86} .1928 \mathrm{~m}$. kovo $24 \mathrm{~d}$. mokyklos viršininko pareigas perėmé kpt. Justinas Kuncaitis, pasižymėjęs Nepriklausomybės kovose su bolševikais ir lenkais ${ }^{87} .1929$ m. gruodžio mènesị i viršininko pareigas buvo paskirtas kpt. Albinas Čepauskas (èjo iki 1934 m. gegužès 14 d.) ${ }^{88}$. Ji pakeitè kpt. Eduardas Berentas, kuris šias pareigas èjo iki 1936 m. liepos 23 d. Ši viršininką pakeitè kpt. Ignas Morkūnas. Jis mokykloje tarnavo iki $1937 \mathrm{~m}$. Tų pačių metų sausio $23 \mathrm{~d}$. ̣̇ KPM viršininko pareigas buvo paskirtas kpt. Jeronimas Sabaliauskas ${ }^{89}$. Jis šias pareigas ejjo iki 1939 m., o tų pačių metų sausio $1 \mathrm{~d}$. buvo paskirtas 1 -osios prieššarvinès kuopos vadu ${ }^{90}$. Nuo 1939 $\mathrm{m}$. sausio $1 \mathrm{~d}$. mokyklos viršininko pareigas pradejjo eiti jau minètas mjr. E. Berentas ${ }^{91}$, jis vadovavo mokyklai iki 1940 m. liepos. Dél pirmosios sovietinès okupacijos metu vykdyto kariuomenès neutralizavimo plano kai kurie aukštesnieji karininkai buvo atleisti arba perkelti $\mathfrak{i}$ kitas pareigas: liepos $2 \mathrm{~d}$. majoras išleistas ị atsargą ${ }^{92}$, o kpt. I. Morkūnas liepos $11 \mathrm{~d}$. paskirtas eiti Lietuvos liaudies kariuomenės KPM viršininko pareigas ${ }^{93}$.

Per dvidešimt KPM gyvavimo metų mokyklos viršininko pareigas ejo septyni karininkai (mjr. E. Berentas ir kpt. I. Morkūnas - du kartus), tarp kurių buvo šeši jaunesnieji karininkai (leitenantai, vyr. leitenantai, kapitonai) ir vienas vyresnysis karininkas (majoras). KPM kuopų ir būrių

1933 m. kovo 10-11 d. Kariuomenès teisme Šiauliuose buvo nagrinëjama kpt. K. RudaičioRudavičiaus byla. Teismas nuteisė ji pusantrų metų kalèti sunkiųjų darbų kalèjime, buvo atimtas karininko laipsnis, bet 1936 m. gruodžio 19 d. Valstybès Prezidento aktu karininko teisès jam buvo grąžintos. Žr.: E. Jacovskis, Už grotų: iš buržuazinès Lietuvos kalejimo istorijos, Vilnius, 1965, p. 151, 165; Rudaitis nuteistas 1 m. 6 mèn. s. d. kal., Dienos naujienos, 1933, Nr. 58, p. 3.

${ }^{85}$ Lietuvos kariuomenes karininkai 1918-1953, Vilnius, 2006, t. VI, p. 279.

${ }^{86}$ Ten pat, 2004, t. IV, p. 179.

${ }^{87}$ Ten pat, p. 313.

${ }^{88}$ Ten pat, 2002, t. II, p. 275.

891937 m. sausio 23 d. Kauno miesto ir apskrities komendanto isakymas Nr. 23/2 komendantūrai, LCVA, f. 1471, ap. 1, b. 42, 1. 23.

${ }^{90}$ Lietuvos kariuomenes karininkai 1918-1953, Vilnius, 2007, t. VII, p. 12-13.

${ }^{91} 1939$ m. vasario 7 d. Kariuomenės vado įsakymas Nr. 3/4, LCVA, f. 1471, ap. 1, b. 46, 1. 95.

92 Lietuvos kariuomenés karininkai 1918-1953, Vilnius, 2002, t. II, p. 167.

${ }^{93}$ Ten pat, 2005, t. V, p. 278-279. 
vadais dažniausiai buvo skiriami jaunesnieji leitenantai, leitenantai arba vyresnieji leitenantai. Paprastai kuopos vado pareigas eidavo turintys leitenanto laipsnị karininkai, išskyrus kpt. J. Sabaliauską, kuris iš mokyklos viršininko pareigų buvo paskirtas prieššarvinès kuopos vadu. Būrio vado teisèmis buvo paskirti trys kapitono laipsnị turintys karininkai: kpt. Stasys Kviecinskas, kpt. Bronius Salikas ir kpt. Osmanas Teizeris, visi kiti - leitenantai. Pažymėtina, kad leitenanto laipsnị turintiems karininkams buvo patikèta mokyklos karių parduotuvès priežiūra, jie buvo skiriami eiti ir KPM ugniagesių komandos viršininko pareigas. Pirmuoju ugniagesių komandos viršininku buvo paskirtas KPM būrio vadas vyr. ltn. Jonas Šipaila ${ }^{94}$. Jis buvo baigęs specialius ugniagesių kursus, todèl kompetentingas vadovauti komandai ${ }^{95}$. Kas vèliau vadovavo KPM ugniagesių komandai, nèra žinoma. Per dvidešimt metų Karo policijos mokykloje viršininkų, kuopos ir būrio vadų pareigas ejjo ne mažiau kaip 36 karininkai.

\section{Karo policijos mokyklos karininkų sąrašas ${ }^{96}$}

\begin{tabular}{|l|l|l|l|}
\hline $\begin{array}{c}\text { Eil. } \\
\text { nr. }\end{array}$ & $\begin{array}{c}\text { Pavardè, } \\
\text { vardas }\end{array}$ & Kario laipsnis & \multicolumn{1}{c|}{ Pastabos } \\
\hline 1. & $\begin{array}{l}\text { Aleksa } \\
\text { Viktoras }\end{array}$ & j. ltn. & $\begin{array}{l}19390329 \text { paskirtas ị Kauno komendantūrą. So- } \\
\text { vietų Sajungai okupuojant Lietuvą tarnavo KPM } \\
\text { 2-osios prieššarvinès kuopos būrio vadu }\end{array}$ \\
\hline
\end{tabular}

\footnotetext{
${ }^{94} 1935$ m. balandžio 25 d. Lietuvos ugniagesių organizacijos ịsakymu vyr. ltn. J. Šipaila už pasižymėjimą priešgaisrineje apsaugoje buvo apdovanotas 2-ojo laipsnio garbès ženklu "Artimui pagalbon“, $1935 \mathrm{~m}$. balandžio $25 \mathrm{~d}$. Kauno miesto ir apskrities komendanto ìsakymas Nr. 115/2 komendantūrai, LCVA, f. 1471, ap. 1, b. 26, 1. 115.

${ }^{95}$ Lietuvos kariuomenés karininkai 1918-1953, Vilnius, 2007, t. VII, p. 308-309.

${ }^{96}$ Sąrašas sudarytas remiantis: Lietuvos kariuomenés karininkai 1918-1953, Vilnius, 2002, t. II, p. 167, 175, 250, 275; ten pat, 2003, t. III, p. 126-127; ten pat, 2004, t. IV, p. 111, $179,245,313$, 335; ten pat, 2005, t. V, p. 155, 194, 267, 278-279, 380; ten pat, 2006, t. VI, p. 77, 92, 110, 251, 279; ten pat, 2007, t. VII, p. 13, 30-31, 33-34, 43-44, 87-88, 102-103, 277, 301, 318; ten pat, 2008, t. VIII, p. 41, 288-289, 306-307, 313; 1937 m. sausio 29 d. Kauno miesto ir apskrities komendantūros karininkų sąrašas, $L C V A$, f. 1126, ap. 2, b. 57, 1. 10; 1940 m. rugsèjo 22 d. Kauno karinio viršininko ịsakymas Nr. 268/2 Kauno karinei istaigai, ten pat, ap. 4, b. 46, 1. 237.
} 


\begin{tabular}{|c|c|c|c|}
\hline 2. & $\begin{array}{l}\text { Berentas } \\
\text { Eduardas }\end{array}$ & $\begin{array}{l}\text { kpt., } 19370908 \\
\text { suteiktas mjr. } \\
\text { laipsnis }\end{array}$ & $\begin{array}{l}19340710 \text { paskirtas KPM viršininku, } 1936 \text { m. } \\
\text { perkeltas ị Kauno karo komendantūrą, } 19390101 \\
\text { paskirtas KPM viršininku ir šias pareigas ejo iki } \\
\text { Lietuvos okupacijos, } 19400702 \text { išleistas ị atsargą }\end{array}$ \\
\hline 3. & $\begin{array}{l}\text { Bikinas } \\
\text { Povilas }\end{array}$ & ltn. & $\begin{array}{l}19291204 \text { paskirtas KPM būrio vadu, } \\
19300611 \text { perkeltas ị pėstininkų kuopą }\end{array}$ \\
\hline 4. & $\begin{array}{l}\text { Butkus } \\
\text { Jurgis }\end{array}$ & plk. ltn. & $\begin{array}{l}19220411 \text { paskirtas KMM 2-osios kuopos būrio } \\
\text { vadu, } 19231126 \text { perkeltas ị II Karo apygardos } \\
\text { štabą }\end{array}$ \\
\hline 5. & $\begin{array}{l}\text { Čepauskas } \\
\text { (Čepas) } \\
\text { Albinas }\end{array}$ & $\begin{array}{l}\text { kpt., } 19301123 \\
\text { suteiktas mjr. } \\
\text { laipsnis }\end{array}$ & $\begin{array}{l}1929 \text { m. gruodžio mèn. paskirtas KPM virši- } \\
\text { ninku, } 19340514 \text { - Generalinio štabo valdybos } \\
\text { Mobilizacijos skyriaus viršininku }\end{array}$ \\
\hline 6. & $\begin{array}{l}\text { Gaidys } \\
\text { Albertas }\end{array}$ & ltn. & $\begin{array}{l}19230103 \text { paskirtas KPM 1-osios kuopos būrio } \\
\text { vadu, } 19240915 \text { perkeltas ị Kauno igulos ko- } \\
\text { mendantūrą }\end{array}$ \\
\hline 7. & $\begin{array}{l}\text { Grinkevičius } \\
\text { Petras }\end{array}$ & mjr. & $\begin{array}{l}19370205 \text { paskirtas KPM būrio vadu, } \\
19371021 \text { miré }\end{array}$ \\
\hline 8. & $\begin{array}{l}\text { Jurgelevičius } \\
\text { Petras }\end{array}$ & ltn. & $\begin{array}{l}19200415 \text { paskirtas KMM jaunesniuoju karinin- } \\
\text { ku, nuo gruodžio mėn. - Ežerèlių (Kauno aps.) } \\
\text { komendanto padejejeju }\end{array}$ \\
\hline 9. & $\begin{array}{l}\text { Kaufmanas } \\
\text { Liudvikas }\end{array}$ & vyr. ltn. & $\begin{array}{l}19240101 \text { paskirtas KPM viršininku, vèliau - } \\
\text { Kauno igulos placadjutantu }\end{array}$ \\
\hline 10. & $\begin{array}{l}\text { Kmieliauskas } \\
\text { Antanas }\end{array}$ & vyr. ltn. & $\begin{array}{l}19200115 \text { paskirtas KMM jaunesniuoju karinin- } \\
\text { ku, vèliau - komandos viršininku, } \\
19200828 \text { - 3-iosios sargybos kuopos vadu. } \\
19220518 \text { iš kariuomenès paleistas eiti aukštojo } \\
\text { mokslo }\end{array}$ \\
\hline 11. & $\begin{array}{l}\text { Kuncaitis } \\
\text { Justinas }\end{array}$ & $\begin{array}{l}\text { kpt., } 19291123 \\
\text { pakeltas ị mjr. }\end{array}$ & $\begin{array}{l}19280324 \text { paskirtas KPM viršininku, } 19291128 \\
\text { - Vyriausiojo kariuomenès štabo Pensijų skyriaus } \\
\text { buhalteriu }\end{array}$ \\
\hline 12. & $\begin{array}{l}\text { Kviecinskas } \\
\text { Stasys }\end{array}$ & $\begin{array}{l}\text { vyr. ltn., } \\
19291123 \\
\text { pakeltas ị kpt. }\end{array}$ & $\begin{array}{l}19280308 \text { paskirtas KPM būrio vadu, } 1931 \\
\text { - KPM viršininko padejjeju, nuo } 19310320 \text { - } \\
\text { Mažeikių šaulių rinktinès vadu }\end{array}$ \\
\hline 13. & $\begin{array}{l}\text { Markauskas } \\
\text { Stasys }\end{array}$ & $\begin{array}{l}\text { j. ltn. } 193910 \\
19 \text { pakeltas i } \\
\text { ltn. }\end{array}$ & $\begin{array}{l}19360915 \text { paskirtas KPM būrio vadu. Sovietų } \\
\text { Sąjungai okupuojant Lietuvą tarnavo Kauno } \\
\text { komendantūros adjutantu }\end{array}$ \\
\hline 14. & $\begin{array}{l}\text { Matutis } \\
\text { Kazys }\end{array}$ & $\begin{array}{l}\text { j. ltn., } \\
19310930 \\
\text { pakeltas ị ltn. }\end{array}$ & $\begin{array}{l}19310411 \text { paskirtas KPM būrio vadu, } \\
19350720 \text { - Kariuomenès štabo I skyriaus } \\
\text { raštvedžiu }\end{array}$ \\
\hline
\end{tabular}




\begin{tabular}{|c|c|c|c|}
\hline 15. & $\begin{array}{l}\text { Miškinis } \\
\text { Vincas }\end{array}$ & ltn. & $\begin{array}{l}19210912 \text { paskirtas KMM 1-osios kuopos vadu, } \\
19220703 \text { - Kauno karo komendantūros Mobili- } \\
\text { zacinio skyriaus vedeju }\end{array}$ \\
\hline 16. & $\begin{array}{l}\text { Morkūnas } \\
\text { Ignas }\end{array}$ & kpt. & $\begin{array}{l}19360723 \text { paskirtas KPM viršininku, } \\
19370116 \text { - 2-osios kuopos vado padejeju, } \\
19400711 \text { - KPM viršininku, } 194011 \text { 15 - RA } \\
\text { 29-ojo ŠTK 179-osios šaulių divizijos 234-ojo } \\
\text { šaulių pulko šaulių kuopos vadu }\end{array}$ \\
\hline 17. & $\begin{array}{l}\text { Pečiulis } \\
\text { Leonardas }\end{array}$ & vyr. ltn. & $\begin{array}{l}19211210 \text { paskirtas KMM 1-osios kuopos būrio } \\
\text { vadu, } 19220218 \text { - paties prašymu išleistas ị } \\
\text { atsargą }\end{array}$ \\
\hline 18. & $\begin{array}{l}\text { Petraitis } \\
\text { Antanas }\end{array}$ & $\begin{array}{l}\text { j. ltn., } \\
19360716 \\
\text { pakeltas ị ltn. }\end{array}$ & $\begin{array}{l}19350801 \text { paskirtas KPM būrio vadu, } \\
19360605 \text { - Karo kalèjimo apsaugos būrio vadu, } \\
19371201 \text { - KPM būrio vadu. Sovietų Sąjungai } \\
\text { okupuojant Lietuvą tarnavo Karo ligoninëje }\end{array}$ \\
\hline 19. & $\begin{array}{l}\text { Petrovas } \\
\text { Jurgis }\end{array}$ & ltn. & $\begin{array}{l}19230201 \text { paskirtas KMM 1-osios kuopos būrio } \\
\text { vadu, } 19230223 \text { - Karo areštinès viršininko } \\
\text { padejejeju }\end{array}$ \\
\hline 20. & $\begin{array}{l}\text { Remeikis } \\
\text { Jonas }\end{array}$ & j. ltn. & $\begin{array}{l}19380512 \text { paskirtas KPM būrio vadu. Sovietų } \\
\text { Sąjungai okupuojant Lietuvą tarnavo Vilniaus } \\
\text { komendantūroje }\end{array}$ \\
\hline 21. & $\begin{array}{l}\text { Rudaitis-Ru- } \\
\text { davičius } \\
\text { Kostas }\end{array}$ & $\begin{array}{l}\text { ltn., } 19260801 \\
\text { pakeltas ị kpt. }\end{array}$ & $\begin{array}{l}19191201 \text { paskirtas Karo lauko milicijos ko- } \\
\text { mandos viršininku, } 19210701 \text { - KMM 1-osios } \\
\text { kuopos viršininku. } 19261221 \text { komandiruotas i } \\
\text { Telšius, } 19270110 \text { paskirtas Varnių koncentraci- } \\
\text { jos stovyklos komendantu }\end{array}$ \\
\hline 22. & $\begin{array}{l}\text { Sabaliauskas } \\
\text { Jeronimas }\end{array}$ & $\begin{array}{l}\text { ltn., } 19311123 \\
\text { pakeltas ị kpt. }\end{array}$ & $\begin{array}{l}19261201 \text { paskirtas KPM būrio vadu, } \\
19270501 \text { - ataskaitos skyriaus vedeju, nuo } \\
19280120 \text { - Kauno m. ir aps. komendantūros } \\
\text { placadjutantu, } 19370116 \text { - KPM viršininku, } \\
19390101 \text { - 1-osios prieššarvinės kuopos vadu, } \\
\text { tuo pat metu ėjo ir mokyklos viršininko padèjëjo } \\
\text { pareigas. } 19400821 \text { perkeltas į Karo ligoninę }\end{array}$ \\
\hline 23. & $\begin{array}{l}\text { Salikas } \\
\text { Bronius }\end{array}$ & $\begin{array}{l}\text { ltn., } 19280216 \\
\text { pakeltas i vyr. } \\
\text { ltn., } 19331120 \\
\text { suteiktas kpt. } \\
\text { laipsnis }\end{array}$ & $\begin{array}{l}19270219 \text { paskirtas KPM būrio vadu. } 192907 \\
\text { - } 09 \text { ėjo Prezidento Antano Smetonos apsaugos } \\
\text { komandos Palangoje viršininko pareigas. } 193311 \\
22 \text { perkeltas ì 1-ajji pèstininkų Lietuvos didžiojo } \\
\text { kunigaikščio Gedimino pulką. } 19340710 \text { paskir- } \\
\text { tas KPM karo policininkų būrio vadu, } 19350720 \\
\text { perkeltas ị Priešlektuvinès apsaugos rinktinę }\end{array}$ \\
\hline
\end{tabular}




\begin{tabular}{|c|c|c|c|}
\hline 24. & $\begin{array}{l}\text { Samuolis } \\
\text { Justinas }\end{array}$ & j. $\operatorname{ltn}$. & $\begin{array}{l}\text { Sovietų Sajungai okupuojant Lietuvą tarnavo KPM } \\
\text { 1-osios prieššarvinės kuopos būrio vadu. } 1940 \\
1003 \text { paskirtas RA 29-ojo ŠTK 184-osios šaulių } \\
\text { divizijos 297-ojo šaulių pulko vado adjutantu }\end{array}$ \\
\hline 25. & $\begin{array}{l}\text { Savickas } \\
\text { Albertas }\end{array}$ & j. ltn. & 19341112 paskirtas KPM būrio vadu \\
\hline 26. & $\begin{array}{l}\text { Skardžius } \\
\text { Povilas }\end{array}$ & j. ltn. & $\begin{array}{l}19360915 \text { paskirtas KPM būrio vadu, 1938- } \\
1939 \text { m. buvo Respublikos Prezidento vasaros } \\
\text { rezidencijos (Užugirio dvare) apsaugos viršinin- } \\
\text { kas. } 19391211 \text { perkeltas ị Kariuomenès teismą }\end{array}$ \\
\hline 27. & $\begin{array}{l}\text { Skučas } \\
\text { Juozas }\end{array}$ & $\operatorname{ltn}$. & $\begin{array}{l}19210319 \text { paskirtas KMM sargybos viršininku } \\
\text { Jonavoje, } 19210701 \text { - KMM būrio vadu, } \\
19220510 \text { - KMM sargybos vadu. } \\
19230109-13 \text { dalyvavo Klaipèdos sukilime, } \\
19231231 \text { išleistas ị atsargą }\end{array}$ \\
\hline 28. & $\begin{array}{l}\text { Šernas } \\
\text { Petras }\end{array}$ & kpt. & $\begin{array}{l}19201213 \text { paskirtas KMM jaunesniuoju kari- } \\
\text { ninku, } 19210611 \text { perkeltas ị Krašto apsaugos } \\
\text { ministeriją }\end{array}$ \\
\hline 29. & $\begin{array}{l}\text { Šimkus } \\
\text { Kazys }\end{array}$ & ltn. & $\begin{array}{l}19260101 \text { paskirtas KPM būrio vadu, } \\
19260930 \text { perkeltas ị Karo aviaciją }\end{array}$ \\
\hline 30. & $\begin{array}{l}\text { Šipaila } \\
\text { Jonas }\end{array}$ & $\begin{array}{l}\text { ltn., } 19280216 \\
\text { pakeltas i vyr. } \\
\text { ltn., } 193512 \\
\text { suteiktas kpt. } \\
\text { laipsnis }\end{array}$ & $\begin{array}{l}19270517 \text { paskirtas KPM būrio vadu, } \\
19310402 \text { - KPM ugniagesių komandos vir- } \\
\text { šininku, } 19350720 \text { perkeltas ị 6-ąji pèstininkų } \\
\text { Pilènų kunigaikščio Margirio pulką }\end{array}$ \\
\hline 31. & $\begin{array}{l}\text { Šleinys } \\
\text { Vincas }\end{array}$ & $\operatorname{ltn}$. & $\begin{array}{l}19300531 \text { paskirtas KPM būrio vadu, } \\
19341130 \text { perkeltas ì 4-ajji péstininkų Lietuvos } \\
\text { Karaliaus Mindaugo pulką }\end{array}$ \\
\hline 32. & $\begin{array}{l}\text { Teizeris } \\
\text { Osmanas }\end{array}$ & kpt. & $\begin{array}{l}19270509 \text { paskirtas KPM būrio vadu, } \\
19271019 \text { perkeltas ị kariuomenės Intendantūrą }\end{array}$ \\
\hline 33. & $\begin{array}{l}\text { Tumas } \\
\text { Kazys }\end{array}$ & $\operatorname{ltn}$. & 19400922 paskirtas KPM apsaugos kuopos vadu \\
\hline 34. & $\begin{array}{l}\text { Zaborskis } \\
\text { Juozas }\end{array}$ & ltn. & $\begin{array}{l}19400101 \text { paskirtas KPM 3-iosios kuopos vadu, } \\
19400109 \text { - Apsaugos bataliono 1-osios kuopos } \\
\text { vadu, } 19401115 \text { perkeltas į 29-ojo ŠTK 184-ąją } \\
\text { šaulių diviziją }\end{array}$ \\
\hline 35. & $\begin{array}{l}\text { Zenkevičius } \\
\text { Pranas }\end{array}$ & $\begin{array}{l}\text { ltn., } 19260801 \\
\text { pakeltas ị vyr. } \\
\text { ltn. }\end{array}$ & $\begin{array}{l}19251030 \text { paskirtas KPM būrio vadu, } \\
19270430 \text { išleistas ị atsargą }\end{array}$ \\
\hline 36. & $\begin{array}{l}\text { Znamenskas } \\
\text { Stepas }\end{array}$ & ltn. & $\begin{array}{l}19400615 \text { paskirtas KPM būrio vadu, } 19401003 \\
\text { - perkeltas į 29-ąj ŠTK 179-ąją šaulių diviziją }\end{array}$ \\
\hline
\end{tabular}




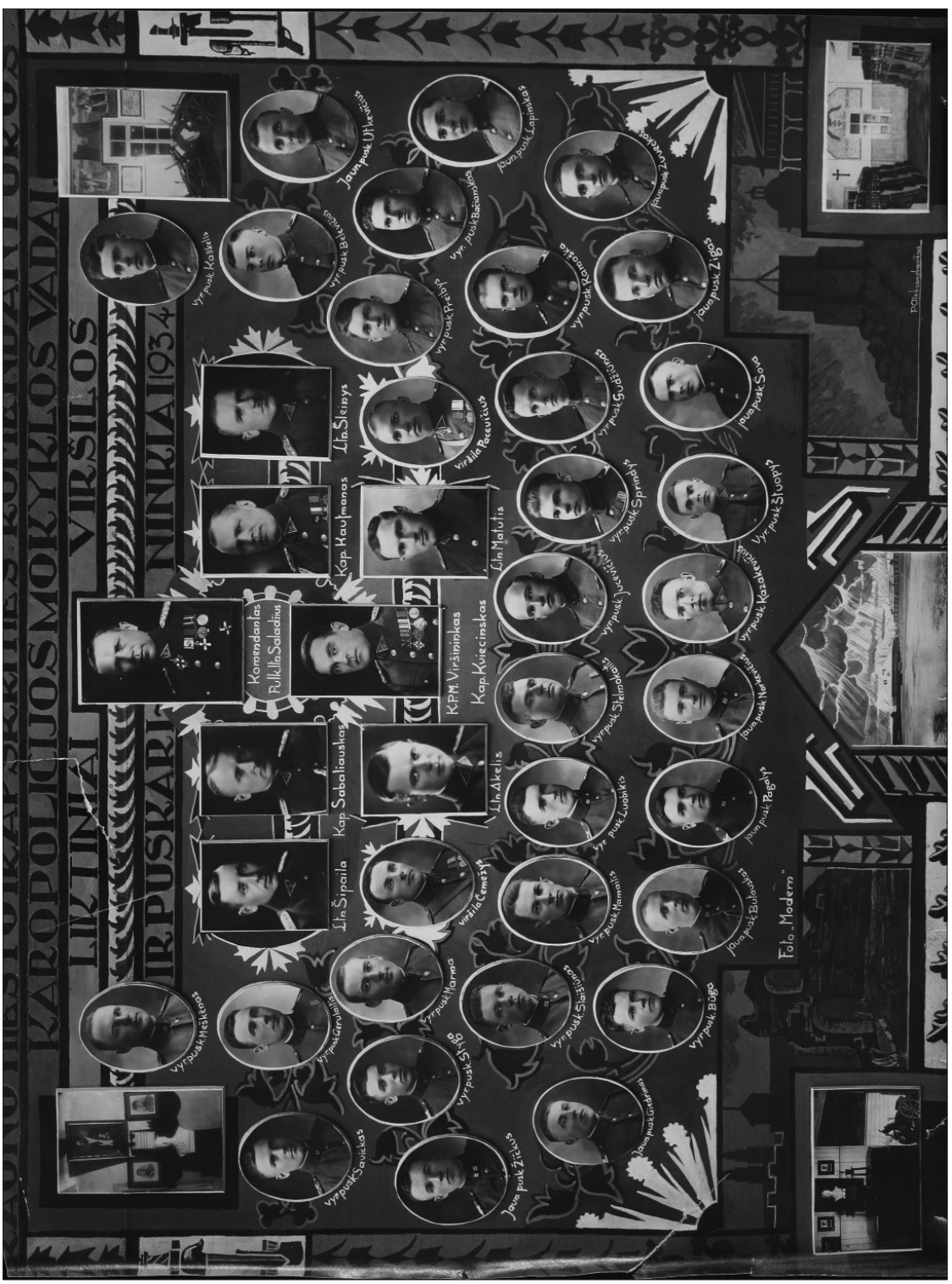

Karo policijos mokyklos vadai, viršilos ir puskarininkiai. 1934 m. (LCVA, V-052) 
Pažymėtina, kad vienu metu KPM sąrašuose buvo penki šeši karininkai ${ }^{97}$, tačiau 1920 m. sąrašuose - net $20^{98}$, vèliau jų skaičius tik mažèjo. KPM kuopininkų ir būrininkų pareigas eiti skiriami viršilos laipsnị turintys kariai, kurių prerogatyva buvo vadovauti karo policininkų būriui ir teikti pagalbą kuopos arba būrio vadui. Jie buvo skiriami eiti ir mokyklos raštininko pareigas, o jų pagalbininkais - vyresnieji puskarininkiai. Viršilos laipsnị turintys kariai ejjo ir ugniagesių komandos viršininko padejjejų bei apsaugos viršininkų pareigas, susijusias su priešgaisrine apsauga ${ }^{99}$. Viršilų etatų mokykloje paprastai būdavo apie keturis ${ }^{100}$. Ginklininko pareigos buvo patikètos vyresniajam puskarininkiui. KPM ùkio reikalams tvarkyti buvo skiriama po vieną vyresnijji ir jaunesnijji puskarininki. KPM buvo trys paramedikų etatai: vyr. paramediko - vyr. puskarininkiui, du j. paramediko - j. puskarininkiams. Žirgų prižiūrètojų, siuvejjų, batsiuvių ir virejų pareigas èjo puskarininkiai ir eiliniai kareiviai $^{101}$. Mokykloje dirbo vienas etatinis civilis tarnautojas - virejas, jo pagalbininkai buvo eiliniai kareiviai ${ }^{102}$. Nera aišku, kas atlikdavo KPM kirpejo pareigas, tikètina, kad tai buvo civilis tarnautojas, nes dokumentuose neminima buvus karių kirpejų etatų.

Konstatuotina, kad Karo policijos mokyklos personalą sudarè kariai ir civiliai (tarnautojai). Karininkai, kurių per visą mokyklos veiklos laikotarpi buvo ne mažiau kaip 36, ejjo mokyklos viršininko, kuopos ir būrio vadų pareigas, buvo atsakingi už priešgaisrinès saugos užtikrinimą, karių parduotuvès darbą. Vienu metu mokykloje tarnavo penki šeši, o viršininko pareigas ejjo septyni karininkai. Kuopininkų, būrininkų, raštininkų pareigas atlikdavo ir priešgaisrinę apsaugą užtikrindavo viršilos, kurių

971931 m. Karo policijos mokyklos paros sudèties žinios, LCVA, f. 1126, ap. 2, b. 214, 1. 1-6; 1940 m. Karo policijos mokyklos paros sudèties žinios, ten pat, b. 290, 1. 45-286.

981920 m. Karo lauko milicijos etatai, ten pat, b. 129, 1. 33.

991934 m. Karo policijos mokyklą baigusių ugniagesių komandos sąrašas, ten pat, f. 1471, ap. 1, b. 5, 1. 30; 1935 m. Karo policijos mokyklos ugniagesių sąrašas, ten pat, b. 24, 1. 4 .

${ }^{100} 1931 \mathrm{~m}$. sausio 2 d. Karo policijos mokyklos paros sudeties žinios, ten pat, f. 1126, ap. 2, b. 214, 1. 1-2; 1939 m. vasario 11 d. Kauno miesto ir apskrities komendanto isakymas Nr. $1 / 3$ komendantūrai, ten pat, ap. 4, b. 331, 1. 8-9ap.

${ }^{101} 1920$ m. Karo lauko milicijos etatai, ten pat, ap. 2, b. 129, 1. 33.

$1021939 \mathrm{~m}$. vasario $11 \mathrm{~d}$. Kauno miesto ir apskrities komendanto issakymas Nr. 1/5 komendantūrai, ten pat, ap. 4, b. 331, 1. 8-9ap. 
paprastai būdavo keturi. Karo policijos mokyklos puskarininkiai buvo skiriami eiti ginklininkų, paramedikų pareigas, tvarkyti ùkio reikalus. Visas kitas pareigas ejo ir puskarininkiai, ir eiliniai kariai. Galima teigti, kad Karo policijos mokyklos personalo sudetis atitiko pagrindinius kriterijus, užtikrinančius tinkamą karinio dalinio funkcionavimą.

\section{Mokyklos vidaus tvarka ir mokymo sistema}

Karo policijos mokyklos vidaus tvarką reglamentavo individuali mokyklos dienotvarke் $\dot{10}^{103}$, ívairios instrukcijos, apibrèžiančios jos vidaus gyvenimą, karių tarnybos organizavimą ir funkcijas pavojaus atveju. KPM dienotvarkè buvo tvirtinama Kauno karo komendanto. Tarnyba prasidèdavo 6, savaitgaliais - 7 val. ryto. Per $20 \mathrm{~min}$. kareiviai turèjo pasirengti rytiniam patikrinimui. 6.30 val. - mankšta ir rytinis pasivaikščiojimas, po pusvalandžio būdavo pusryčiai. Nuo 8 iki 11 val. vykdavo pamokos. Nuo 11 iki 14 val. - kareivių laisvalaikis, pietūs (12 val.). Nuo 14 iki 18 val. vèl vykdavo pamokos (įskaitant valandą laisvo laiko po jų). 19 val. - vakarienè, po jos nuo 19.30 iki 20.30 val. - laikas kareivių pasivaikščiojimui su dainomis. Vakarinis patikrinimas vykdavo 20.45 val., o poilsio laikas (miegas) prasidedavo 22 val. ${ }^{104}$

1935 m. rugsèjo 22 d. Kauno karo komendantas plk. ltn. Zigmas Talevičius padarè tam tikrų pakeitimų. Rytinis patikrinimas buvo pailgintas nuo 10 iki 30 min., pusryčių laikas - nuo 7.20 iki 7.50 val., t. y. sutrumpintas nuo valandos iki pusvalandžio, pamokos turejjo vykti iki pietų (12 val.), laisvalaikiui skirtas laikas tarp pamokų - nuo 12.30 iki 14 val., o pamokos baigdavosi ne 18 val., kaip anksčiau, o 17 val., vakarienė paankstinta viena valanda. Visa kita liko, kaip buvo ${ }^{105}$. Pažymėtina, kad dienotvarkè buvo sugriežtinta, sutrumpintas kareivių laisvalaikis nuo keturių

${ }^{103}$ Dienotvarkè - paros laiko paskirstymas kariniame dalinyje; nustato kasdieninę karių tarnybos, mokymo ir buities organizavimo tvarką: Karybos žodynas, red. A. Mackevičienė, Vilnius, 1995, p. 59.

$1041930 \mathrm{~m}$. sausio $3 \mathrm{~d}$. Kauno miesto ir apskrities komendanto isakymas Nr. 3/3 komendantūrai, LCVA, f. 1126, ap. 4, b. 37, 1. 3ap.

1051935 m. rugsèjo 22 d. Kauno miesto ir apskrities komendanto isakymas Nr. 268/2 komendantūrai, ten pat, f. 1471, ap. 1, b. 26, 1. 274. 
iki dviejų su puse valandos. 1937 m. Kauno karo komendantas KPM patvirtino atskiras vasaros ir žiemos laiko dienotvarkes: gegužès 1-rugsėjo 15 d. galiojo vasaros laikas, rugsèjo 15-gegužès 1 d. - žiemos. Pagal vasaros laiko dienotvarkę kariai keldavosi 5 val. ryto, galèjo ilsètis nuo 21 val., pagal žiemos laiko dienotvarkę - keldavosi 6 val., ilsėdavosi - nuo 22 val. Po vakarienės, užuot poilsiavus, buvo ruošiamasi kitos dienos pamokoms $^{106}$. KPM karių dienotvarkè buvo dar kartą sugriežtinta daugiau laiko skiriant mokslui.

Mokyklos instrukcijose taip pat buvo reglamentuota paros tarnybu ir budejjimų tvarka mokyklai priklausančioje teritorijoje. Didžiausia atsakomybė už tvarką ir budejimo paskirstymą teko mokyklos budètojui. Teiktinas toks pavyzdys. $1936 \mathrm{~m}$. rugsejo $28 \mathrm{~d}$. instrukcijoje KPM budètojams nurodyta, kad viršininkas skiria mokyklos budetoją, kuris tarnybą turi pradèti 13 val. ${ }^{107}$ Pagal $1937 \mathrm{~m}$. lapkričio $16 \mathrm{~d}$. instrukciją budejjimas prasidèdavo vakarinio patikrinimo metu ${ }^{108}$. Taip buvo pakeista budejimo pradžia. Mokyklos budètojas tiesiogiai buvo pavaldus kuopininkui. Svarbiausia budètojo užduotis buvo prižiūrèti tvarką kareivinèse ir mokyklos teritorijoje, stebèti karių elgesį, kontroliuoti mokyklos vidaus gyvenimą. Budètojo kompetencijai priklausè ir tvarkdarių skirstymas mokyklos teritorijoje, jų priežiūra ${ }^{109}$. Lauko tvarkdarius mokyklos budètojas skirdavo ị dvi vietas: prie mokyklos vartų ir kieme iš Aukštaičių g. ir Kudirkos al. pusès ${ }^{110}$. Tvarkdariai prie mokyklos vartų buvo skiriami tris kartus per parą, jų pareiga buvo kontroliuoti judejjimą pro vartus ị mokyklos teritoriją ir iš jos, tikrinti įeinančiųjų dokumentus, leidimus, neịleisti pašalinių. Apie

\footnotetext{
1061937 m. gegužès 2 d. Kauno miesto ir apskrities komendanto ísakymas Nr. 122/2 komendantūrai, ten pat, b. 42, 1. 123; 1937 m. rugsèjo 12 d. Kauno miesto ir apskrities komendanto įsakymas Nr. 257/2 komendantūrai, ten pat, 1. 260.

${ }^{107} 1936$ m. rugsejjo 28 d. instrukcija Kauno miesto ir apskrities komendantūros Karo policijos mokyklos budètojams, ten pat, b. 6, 1. 11 .

1081937 m. lapkričio 16 d. Karo policijos mokyklos budetojo instrukcija, ten pat, 1. 1414 ap.

109 Ten pat.

${ }^{110} 1939 \mathrm{~m}$. sausio $9 \mathrm{~d}$. instrukcija lauko tvarkininkui prie Karo policijos mokyklos vartų, ten pat, 1. 45; 1935 m. gruodžio 1 d. instrukcija lauko tvarkininkui Karo policijos mokyklos kieme, ten pat, 1. 3 .
} 
pažeidimus turèjo būti pranešama mokyklos budètojui ${ }^{111}$. Lauko tvarkdariai mokyklos kieme buvo skiriami du kartus per parą: po vakarinio patikrinimo iki kèlimosi ir po kèlimosi iki vakarinio patikrinimo. Tvarkdariai privalejo patruliuoti mokyklos teritorijoje - nuo Aukštaičių g. ir Kudirkos al. pusės iki mokyklos kareivinių pietinès dalies. Jų pareiga buvo tikrinti kareivines, puskarininkių bendrabutị, administracinius ir ūkinius pastatus, sandèlius. Jie visada turẻjo palaikyti ryšį su tvarkdariu prie vartų, apie pastebėtus pažeidimus pranešti mokyklos budètojui ${ }^{112}$. Be lauko tvarkdarių, mokyklos budètojas skirdavo ir tvarkdarị budèti valgykloje, budètoją kirpykloje. Valgyklai prižiūrèti buvo sudaromos trys pamainos, kurios turejjo keistis kas dvi, o naktį - kas tris valandas. Pietų ir vakarienès metu tvarkdariai privalejo prižiūrèti valgykloje padètus ginklus, tvarką ir švarą, neịleisti pašalinių asmenų, net padengti stalus ir po valgio išplauti indus ${ }^{113}$. Kirpyklos budètojai turejo palaikyti tvarką, švarą ir rimtị, registruoti atejusius kirptis ${ }^{114}$. Tvarkdarių atliekamas pareigas visada turejo tikrinti ir kontroliuoti mokyklos budètojas, apie pažeidimus pirmiausiai pranešti kuopininkui. Taigi, budètojų ir tvarkdarių tarnybos buvo organizuojamos taip, kad užtikrintų vidaus tvarkos ir drausmès taisyklių laikymąsi.

1938 m. pabaigoje, esant įtemptai tarptautinei situacijai Vakarų Europoje, buvo susirūpinta valstybès apsauga. $1938 \mathrm{~m}$. spalio $7 \mathrm{~d}$. buvo parengtas slaptas Kauno komendantūros ir Karo policijos mokyklos pasirengimo pavojaus atveju planas, kuris turèjo būti panaudotas kilus kitų valstybių kariuomenių i̇siveržimo grésmei. KPM kariams pavojaus atveju buvo numatytos tam tikros funkcijos. Pirmiausia KPM parengties dalies viršininkas, gavęs krašto apsaugos ministro ar Kauno komendantūros ịsakymą, privalejo iš karto skelbti pavojaus signalą, kariai - susirinkti KPM kareivių patalpose, o karininkai, du eiliniai ir vienas puskarininkis - būti pasiųsti i̇ komendantūrą. Nedelsdama KPM turẻjo sustiprinti sargybą

${ }^{111} 1939$ m. sausio 9 d. instrukcija lauko tvarkininkui prie Karo policijos mokyklos vartų, ten pat, 1. 45.

1121935 m. gruodžio 1 d. instrukcija lauko tvarkininkui Karo policijos mokyklos kieme, ten pat, 1. 3 .

${ }^{113} 1940$ m. liepos 26 d. instrukcija Karo policijos mokyklos valgyklos tvarkininkui, ten pat, 1. 48.

${ }^{114} 1936$ m. rugsèjo 26 d. instrukcija Karo policijos mokyklos kirpyklos budètojui, ten pat, 1. 13. 
prie Respublikos Prezidento rūmų, Kariuomenès štabo, skirti aštuonių karių ginkluotą sargybą prie Vyriausybès rūmų, saugoti centrinę telefono-telegrafo stotị ir elektrines, patruliai - palaikyti ryšị su 1-uoju husarų Lietuvos didžiojo etmono kunigaikščio Jonušo Radvilos ir 2-uoju Lietuvos didžiojo kunigaikščio Algirdo pėstininkų pulkais. Paskelbus pavojų, KPM turejo būti skiriamos susisiekimo priemonès: vienas motociklas su priekaba ir vienas sunkvežimis. Likę mokykloje kariai turèjo būti nustatytos parengties - apginkluoti šautuvais (kiekvienam skyrus po 90 šovinių), kulkosvaidžiais (kiekvienam skyrus po 500 šovinių), granatomis ir laukti išsamesnių nurodymų ${ }^{115}$. Priešiškos valstybès kariuomenès įsiveržimo atveju KPM buvo patikèta svarbių valstybinės reikšmės objektų apsauga ir gynyba. Iš šios instrukcijos matyti, kad karo policininkų tarnyba užtikrinant valstybès saugumą buvo reikšminga.

Karo policijos mokyklos karių mokymo sistema buvo paremta šešių savaičių bendruoju teoriniu ir praktiniu pėstininkų mokymu ${ }^{116}$, kurị sudarẻ bendrieji karo tarnybos dalykai - Pėstininkų, Vidaus ir Lauko tarnybų, Šautuvų ir Drausmès statutai ${ }^{117}$. Šiai mokymo programai skyrus nedaug laiko, kariai buvo tik paviršutiniškai supažindinami su teorija ir praktika. Perèję ì mokomąjị būrị, jie toliau kaupe įvairių dalykų žinias: nagrinėjo Rikiuotès statuto teoriją ir praktiką, Igulos, Vidaus tarnybos, Drausmès, Karo lauko statutus, gilinosi i vokiško „Mauser 98“ šautuvo ypatumus ir šaudymo teoriją, mokèsi topografijos. Mokymo programą sudare ir bendrojo lavinimo dalykai: lietuvių kalba, matematika, istorija, geografija, gamtos mokslai ${ }^{118}$, o policijos veiklos ir teismo dalykai buvo priskirti prie specialiųjų ${ }^{119}$. Mokymo metu kariai buvo supažindinami su valstybès ir kariuomenès administracine struktūra, karinių ir civilinių teismų veikimo

\footnotetext{
${ }^{115} 1938$ m. spalio 7 d. Kauno komendantūros ir Karo policijos mokyklos slaptas pavojaus pasirengimo planas, ten pat, f. 930, ap. 7, b. 6752, 1. 83.

${ }^{116}$ V. Statkus, Lietuvos ginkluotos pajegos 1918-1940 m., p. 423.

${ }^{117} 1937$ m. Karo policijos mokyklai reikalingų statutų sąrašas, LCVA, f. 1471, ap. 1, b. 10, 1. 45-45ap.

${ }^{118}$ Lietuvių kalbos, istorijos ir geografijos pamokas vedè Kauno komendantūros švietimo komisijos pirmininkas ltn. Domas Šidlauskis-Visuomis: L. Kastanauskaitė, Lietuvos inteligentija masonu ir paramasoniškose organizacijose (1918-1940), Vilnius, 2008, p. 292. ${ }_{119} 1920$ m. birželio 22 d. Karo milicijos mokyklos 3 ménesių mokslo kurso baigimo liudijimas, $L C V A$, f. 1471, ap. 1, b. 1, 1. 1.
} 
principais, turejjo suprasti nusikaltimo sąvoką, išmokti taikyti ikiteisminio tyrimo vykdymo (kratos, arešto, tardymo ir pan.) principus, išmanyti įstatymus, susijusius su slaptaisiais tyrimais ${ }^{120}$. Baigę mokymo kursą kariai privalèjo laikyti šių mokomųjų dalykų egzaminus ir pademonstruoti igytus igūdžius ${ }^{121}$.

Po pradinio mokymo likusiems toliau tarnauti mokykloje buvo rengiamos priesaikos ceremonijos, o po jų - paskaitos apie priesaikos reikšmę kariuomenejje ${ }^{122}$. Vèliau mokymo laikas ir mokomieji dalykai kito. Pradinis mokymas trukdavo keturias savaites, po to gabiausi kariai buvo perkeliami ị mokomajji būrị ${ }^{123}$. Šiame būryje šešis ménesius buvo rengiami karo policininkai. Nesunku pastebėti, kad mokomųjų dalykų skaičius didejo, o karo policininkų rengimas tobulejo. Mokomojo būrio mokymo programa buvo sudaryta iš karinio rengimo ir bendrojo lavinimo (švietimo) dalykų. Karinis rengimas buvo paremtas pėstininkų mokymo programa. Daugiausia dèmesio buvo skiriama rikiuotès, kautynių, igulos tarnybos, sargybos, kariuomenès drausmès, karo policijos tarnybos, ginklų ir šaudymo dalykams. Jie buvo dažnai kartojami, dėstomi visą laiką lygiagrečiai su kitais teoriniais ir praktiniais dalykais. Tiesa, kariams buvo teikiamos teorinès žinios ir apie cheminio ginklo naudojimą, priešcheminę, priešlèktuvinę, prieššarvinę apsaugą ${ }^{124}$, durtuvų kautynių ypatybes, topografiją, fortifikaciją, ryšių priemones (taip pat supažindinama praktiškai), rengiamos higienos ir tikybos paskaitos.

Praktiniai igūdžiai buvo tobulinami šaudymo, granatų mètymo, apka-

${ }^{120} 1922$ m. Karo milicijos mokyklos desniai, ten pat, f. 1126, ap. 2, b. 222, 1. 15-15ap.; A. Stoliarovas, Lietuvos Respublikos kariné teisèsauga: Armijos teismas 1919-1922 metais, Karo archyvas, 2010, t. 25, p. 179.

${ }^{121} 1920$ m. birželio 22 d. Karo milicijos mokyklos 3 mènesių mokslo kurso baigimo liudijimas, ten pat, f. 1471, ap. 1, b 1, 1. 1.

$1221935 \mathrm{~m}$. spalio 24 d. Kauno miesto ir apskrities komendanto issakymas Nr. 300/2 komendantūrai, ten pat, b. 26, 1. 306.

1231939 m. kovo 29 d. Karo policijos mokyklos viršininko raportas Kauno miesto ir apskrities komendantui dèl mokomųjų programų tobulinimo, ten pat, b. 10, 1. 123.

${ }^{124}$ Bendroji prieššarvinè, priešcheminė ir priešlèktuvinè apsauga buvo dėstoma nuo 1938 m. Prieššarvine apsauga susirūpinti vertė tobulejjanti užsienio valstybių karo technika: Ar pakankamai pasirengę kovai su šarvuočiais? Kardas, 1937, Nr. 12, p. 283. 


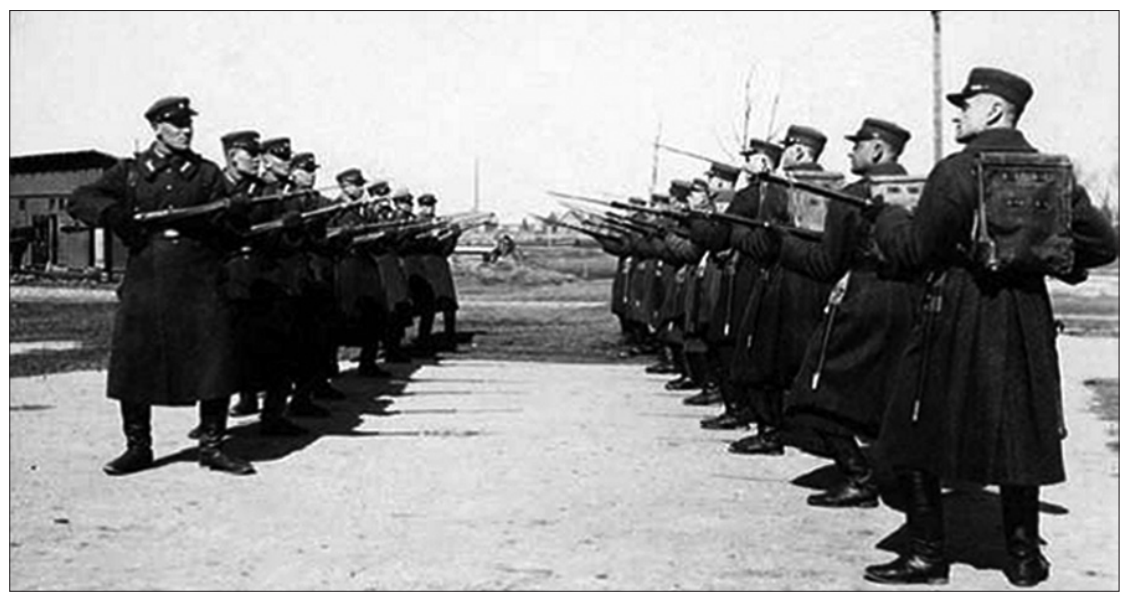

Karo policininkų karinès pratybos - durtuvų naudojimo technika - Kaune. XX a. 3-iasis dešimtmetis. (Krašto apsauga, 2009, Nr. 5, p. 10)

sų įrengimo, taktinių manevrų pratybų metu ${ }^{125}$. Karių šaudymo pratybos vykdavo Eigulių šaudykloje ${ }^{126}$, kitos - Gaižiūnų poligone. Visus numatytus šaudymo pratimus kariai ne visada atlikdavo dẻl šovinių trūkumo. Ši problema kildavo gana dažnai ${ }^{127}$. Ne visada buvo suspèjama surengti pratybas ir išeiti teorinị mokymo kursą ir dèl to, kad kariai turejjo eiti ịvairias pareigas ${ }^{128}$. Kad ir daug dèmesio skiriant karo policininko mokymui, $\mathrm{XX}$ a. 4-ajame dešimtmetyje mokymo programoje mažiau laiko buvo numatyta specialiesiems dalykams, o daugiau - kariniam rengimui. Šios karo policininkų mokymo programos metu buvo ne tik supažindinama su karo policijos tarnyba (teisèmis, pareigomis, drausmès taisyklių laiky-

${ }^{125} 1936-1937$ m. Karo policijos mokyklos kareivių užsiemmimų programos, LCVA, f. 1471, ap. 1, b. 41, 1. 1-37.

${ }^{126} 1937$ m. lapkričio $10 \mathrm{~d}$. Kauno miesto ir apskrities komendanto ịsakymas Nr. 317/5 komendantūrai, ten pat, b. 42, 1. 321.

${ }^{127} 1932$ m. lapkričio $11 \mathrm{~d}$. Karo policijos mokyklos viršininko raportas Kauno miesto ir apskrities komendantui dèl mokymo programų ịvykdymo, ten pat, b. 1, 1. 18ap; 1937 m. kovo 31 d. Karo policijos mokyklos mokymo sèkmingumo žinios, ten pat, b. 47, 1. 96; 1938 m. birželio 27 d. Karo policijos mokyklos viršininko raportas Kauno miesto ir apskrities komendantui dèl mokomųjų šovinių trūkumo, ten pat, b. 10, 1. 70.

${ }^{128}$ Ten pat. 
mosi kontrole, ịvairaus pobūdžio apsauga, tvarkos palaikymu viešosiose vietose, asmenų sulaikymu ir areštu, konvojavimu, žvalgyba (karo metu), kvota, dezertyrų gaudymu ir pan.), bet ir mokoma tinkamai ją atlikti. Igyvendinant minètą programą buvo naudojamos karo policininkų tarnybos instrukcijos, pareigų ir teisès normų aprašai, ịstatymai, Lietuvos ir užsienio šalių karinè literatūra ir poligonų statutai ${ }^{129}$. Šios programos dalykus kariai turejo išmokti nepriekaištingai, kadangi jos esmè buvo susijusi su tiesiogine (tolesne) karo policininko tarnyba.

Fizinis kareivių lavinimas vyko pagal Kariuomenés fizinio lavinimo inspekcijos sudarytas mankštos mokymo programas, kurios buvo bendros visoms kariuomenès dalims. Mankštos programai atlikti buvo skiriamos 2 val. per dieną (iš viso 24 val.), o visa programa turèjo būti ịvykdyta per dvi savaites. Ji buvo sudaryta iš aštuonių pagrindinių dalykų: mankštos vedimo (7 val.), lengvosios atletikos (4 val.), žaidimų (futbolo, tinklinio, krepšinio) (3 val.), žaidimų ir mankštos pamokų („Trečias bèga“, „Žalčio uodegos gaudymas“, estafetès ir pan.) (2 val.), šliaužimo (1 val.), granatų mètymo (1 val.), lauko kliūčių ịveikimo (2 val.) ir mankštos su prietaisais (4 val.) $)^{130}$. Programos tikslas buvo supažindinti kareivius su ịvairiais mankštos pratimais, išmokyti taisyklingai juos atlikti, suteikti teorinių žinių apie sportinius ir pramoginius žaidimus, jų taisykles ir taktiką, supažindinti su šliaužimo būdais, granatų mètymo taktika ir lauko kliūčių ịveikimo būdais. Karių, ìvykdžiusių aptartąją mokomojo būrio programą, žinioms ịvertinti buvo skirti 23 egzaminai: rikiuotès, fizinio lavinimo, šautuvo, lengvojo kulkosvaidžio, pistoletų, šaudybos, automatinių pabūklų, granatų, Vidaus tarnybos, Drausmès statutų, igulos ir sargybos tarnybos, bendrųjų žinių (tarnybos eiga, maisto daviniai, kareivių apranga ir algos, ginkluotųjų pajègų vadovybė ir organizacija $)^{131}$, priešlèktuvinès, priešcheminès, prieššarvinès apsaugos, žemèlapių studijavimo, karo lauko rengimo, ginklų rūšių, krašto saugumo, užsienio valstybių šautuvų,

\footnotetext{
${ }^{129} 1936$ m. birželio 16 d. Karo policijos mokyklos mokomojo būrio karo policininkų mokymo programa, ten pat, 1. 27-27ap.

${ }^{130} 1934 \mathrm{~m}$. gruodžio $21 \mathrm{~d}$. viršiloms, puskarininkiams ir grandiniams privalomos mankštos mokymo programa, ten pat, b. 1, 1. 113-115 ap.

${ }^{131} 1936-1937$ m. Karo policijos mokyklos kareivių užsiėmimų programos, ten pat, b. 41, 1. 2ap, 3ap, 11 ap.
} 
švietimo (Lietuvos istorija nuo seniausiųjų laikų iki Mindaugo, Liublino unija, Abiejų Tautų Respublikos padalijimai, XIX a. istorija, Didysis Vilniaus seimas, vokiečių okupacija, Kauno komendantūros darbai, istorinès asmenybės, perskaityto teksto atpasakojimas, nesudetingų matematikos uždavinius sprendimas ir Europos geografijos žinios) ${ }^{132}$, taktinio mokymo ir karo policijos tarnybos. Tenka pridurti, kad Žemès ūkio rūmų agronomai KPM kariams skaitė paskaitas apie ūkio srities dalykus. Jų klausè ir Karo kalejjimo, Šarvuočių rinktinès kariai ${ }^{133}$.

Taip pat pažymėtina, kad KPM rūpintasi alkoholio vartojimo prevencija - kariams buvo skaitomos paskaitos apie jo žalą ${ }^{134}$. Minètinos ir paskaitos, skirtos bendrajam kareivių išsilavinimui, šių kursų dalykų egzaminų laikyti nereikejo. Kariams, baigusiems mokyklą ir toliau tęsiantiems tarnybą karo policijoje, mokslas nesibaigdavo. KPM liktinių puskarininkių profesinès tarnybos žinioms gilinti buvo rengiami specialūs kursai, susiję su karybos dalykais. Šių kursų tikslas buvo papildyti puskarininkių teorines ir praktines žinias, tobulinti vadovavimo lauko pratyboms igūdžius ${ }^{135}$.

Karo policijos mokyklos kariams, paskirtiems ị ugniagesių komandą, buvo privalomas dar ir priešgaisrinès apsaugos rengimas, vykdomas pagal specialias mokymo programas. KPM ugniagesių komandos eiliniai kareiviai buvo rengiami pagal $1931 \mathrm{~m}$. lapkričio $12 \mathrm{~d}$. patvirtintą mokymo programą, skirtą visiems kariuomenès ugniagesiams (eiliniams) rengti. Mokymo programų tikslas buvo supažindinti karius su ugniagesių darbo ypatumais - darbu su gesinimo ịrenginiais, kirviu, apsaugos priemonèmis ir kt., parengti juos taip, kad ugniagesio funkcijas galètų tinkamai atlikti ir išeję iš kariuomenès. Ugniagesių mokymas vyko pakopomis: 1 pakopa teorija (52 val.), 2 pakopa - praktika (52 val.). Šiai programai igyvendinti buvo skiriama po dvi valandas per savaitę ${ }^{136} .1939 \mathrm{~m}$. kovo $25 \mathrm{~d}$. buvo patvirtinta nauja kariuomenės ugniagesių mokymo programa, orientuota i minimalų ugniagesių apmokymą, paliekant kariams daugiau laiko tiesio-

\footnotetext{
${ }^{132}$ Ten pat, 1. 1-37.

${ }^{133}$ Ükio paskaitos kareiviams, Karys, 1934, Nr. 9, p. 176.

${ }^{134}$ Itvairina kareivių gyvenimą, ten pat, 1934, Nr. 3, p. 54.

${ }^{135}$ Stengiasi daugiau kariškai išsilavinti, ten pat, 1934, Nr. 6, p. 116.

${ }^{136}$ A. Ružancovas, Karių-ugniagesių (eilinių) mokymas, Lietuvos gaisrininkas, 1932, Nr. 3 , p. 9-11; A. Ružancovas, Karių-ugniagesių (eilinių) mokymas, ten pat, 1932, Nr. 4, p. 8-10.
} 
ginei tarnybai. Pagal šią mokymo programą ugniagesiams mokyti buvo skiriamos tik 48 val. (anksčiau - 104 val.), supaprastinta mokymo teorija ir praktika supažindinant karius su ugniagesių veiksmais gaisro metu, gesinimo įrankiais, jų parengimu naudoti ${ }^{137}$.

1939 m. KPM prieššarvinių kuopų mokymo programos beveik nesiskyrè nuo bendrųjų mokomosios kuopos mokymų. Šių kuopų kariams buvo dèstomi visi privalomieji karybos ir bendrojo lavinimo dalykai, tačiau pastariesiems skiriama ne tiek daug demesio. Nebuvo mokoma ir karo policininko tarnybos, nes kuopos paskirtis buvo kita. Prieššarvinès apsaugos mokymas buvo specialus, susijęs su šios srities teorija ir praktika. Specialiajam mokymui buvo skiriamas ypatingas dèmesys, nes kuopos turejjo daugiau pamokų, susijusių su prieššarvine apsauga, buvo rengiama daug pratybų ${ }^{138}$. Pvz., šaudymo pratybose buvo naudojami specialūs rusiško tanko formos taikiniai, vadinami „tankeliais“"139, ịrengti ant specialių bėgių, $36 \mathrm{~cm}$ aukščio ir $72 \mathrm{~cm}$ ilgio ${ }^{140}$. Prieššarvinès kuopos turejjo būti gerai parengtos, kad prireikus galètų tinkamai reaguoti, kadangi buvo neatmetama lenkų puolimo grèsmè. 1939 m. rugpjūčio 4 d. Lietuvos kariuomenės II pėstininkų divizijos štabas paskelbė priedangai vykdyti direktyvą „L“. Vienai iš galimų lenkų puolimo krypčių Kaunas-Vilnius apsaugai užtikrinti buvo sudaryta Kaišiadorių priedangos rinktinè, ị kurios sudètị ¡èjo ir abi KPM prieššarvinès kuopos ${ }^{141}$.

Galima teigti, kad Karo policijos mokyklos mokymo sistema buvo orientuota ị ịvairiapusị karo policininko rengimą, nes jo metu buvo suteikiama ne tik karybos, bet ir kitų dalykų, kuriuos privalo išmanyti kiekvienas išsilavinęs pilietis, žinių ir praktinių ịgūdžių. Be to, kariai, siekiantys igyti ugniagesio kvalifikaciją, buvo supažindinami su priešgaisrinès apsaugos principais ir atitinkamai mokomi.

\footnotetext{
${ }^{137}$ A. Ružancovas, Kariuomenès ugniagesių mokymas, Ugniagesys, 1939, Nr. 5, p. 38. ${ }^{138} 1940 \mathrm{~m}$. Karo policijos mokyklos 1-osios prieššarvinès kuopos mokymo darbotvarkè, LCVA, f. 1471, ap. 1, b. 112, 1. 1-53; 1940 m. Karo policijos mokyklos 2-osios prieššarvinès kuopos mokymo programos, ten pat, b. 116, 1. 1-47.

${ }^{139} 1939$ m. šaudyti ị šarvuočius naudojamo įtaiso („tankelio“) aprašymas, ten pat, b. 106, 1. 1. ${ }^{140} 1939$ m. „Tankelio“ schematinis vaizdas iš šono, ten pat, 1. 4.

${ }^{141}$ V. Lesčius, Lietuvos kariuomenès organizavimo, dislokavimo ir ginkluotès pokyčiai 1938-1940 m., Karo archyvas, 2009, t. 24, p. 152.
} 


\section{Karo policijos karių uniforma, ginkluotė ir kita atributika}

1919 m. pabaigoje iš JAV ị Lietuvą buvo atgabenta karinès aprangos siunta - kelios dešimtys tūkstančių žalsvai gelsvos spalvos uniformų (milinių, mundurų ${ }^{142}$, kelnių) ir kitų daiktų ${ }^{143} .1919$ m. pabaigoje KMM kareiviai buvo aprūpinti būtent šiomis atgabentomis amerikietiškomis uniformomis, tik su lietuviškais skiriamaisiais ženklais ${ }^{144}$. 1920 m. viduryje buvo parengtas karo milicininko uniformos projektas: geltonas antpetis (smailusis galas $-3 \mathrm{~cm}$ pločio, platusis $-6 \mathrm{~cm}$ ), kurio viduryje balta ietis, geltonos kelnių juostos ( $3 \mathrm{~cm}$ pločio antsiuvai ${ }^{145}$ ), kepurès lankelio viršuje geltonos spalvos (1 mm pločio) juostele $\dot{e}^{146} .1920 \mathrm{~m}$. Steigiamajame Seime uniformą pademonstravo du KMM kareiviai, tačiau jos projektas nebuvo patvirtintas, motyvuojant tuo, kad Lietuvai nereikia išskirtinai atrodančių karo milicininkų, nes tai primintų priklausomybès carinei Rusijos imperijai laikus, kai veikè karo žandarmerijos ${ }^{147}$. Todèl mokyklos kariams galiojo bendrieji kariuomenès uniformos dévejjimo nuostatai. XX a. 3-iojo dešimtmečio viduryje KPM kariai jau dèvejjo lietuvišką (1920 m.) uniformą. Kasdieninè karo policininko, kaip ir lauko, uniforma buvo sudaryta iš munduro, susegamo viena eile sagų dešiniajame šone ir sujuosiamo diržu per liemenị, kepurès su snapeliu, kelnių, sukišamų i ilgus aulinius batus.

Žiemą buvo dèvima milinè, sujuosta diržu. Tačiau 1929 m. kareivių mundurai šiek tiek pakito, susegimas buvo ne šone, kaip anksčiau, o viduryje $^{148} .1931 \mathrm{~m}$. sausio 28 d. Respublikos Prezidentui patvirtinus ka-

\footnotetext{
${ }^{142}$ Milinè - iš milo siuvama, panaši ì paltą karių uniformos dalis. Munduras - karių uniforminis švarkas, Karybos žodynas, red. A. Mackevičienè, p. 147, 155.

${ }^{143}$ J. Vaičenonis, Lietuvos karių uniformos ir lengvieji ginklai XX amžiuje, Vilnius, 2004, p. 39. ${ }^{144}$ J. Demereckis, Savanorio ir kontržvalgybininko atsiminimai, p. 36.

${ }^{145}$ Antsiuvas - kitokios spalvos negu kelnių medžiagos juosta, prisiūta išilgai šoninių kelnių siūlių, Karybos žodynas, red. A. Mackevičienè, p. 136.

${ }^{146} 1920$ m. Karo lauko milicijos uniformos projektas, LCVA, f. 1126, ap. 2, b. 129, 1. 31; A. Stoliarovas, Lietuvos Respublikos karinè teisèsauga: Armijos teismas 1919-1922 metais, Karo archyvas, 2010, t. 25, p. 180.

${ }^{147}$ J. Demereckis, Savanorio ir kontržvalgybininko atsiminimai, p. 45.

${ }^{148}$ Karo policijos mokyklos kareiviai po priesaikos su Kauno miesto ir apskrities komendantu plk. ltn. Pranu Saladžiumi priešakyje, Kauno karo komendantūra 19191929, red. P. Jurgelevičius, p. 39.
} 


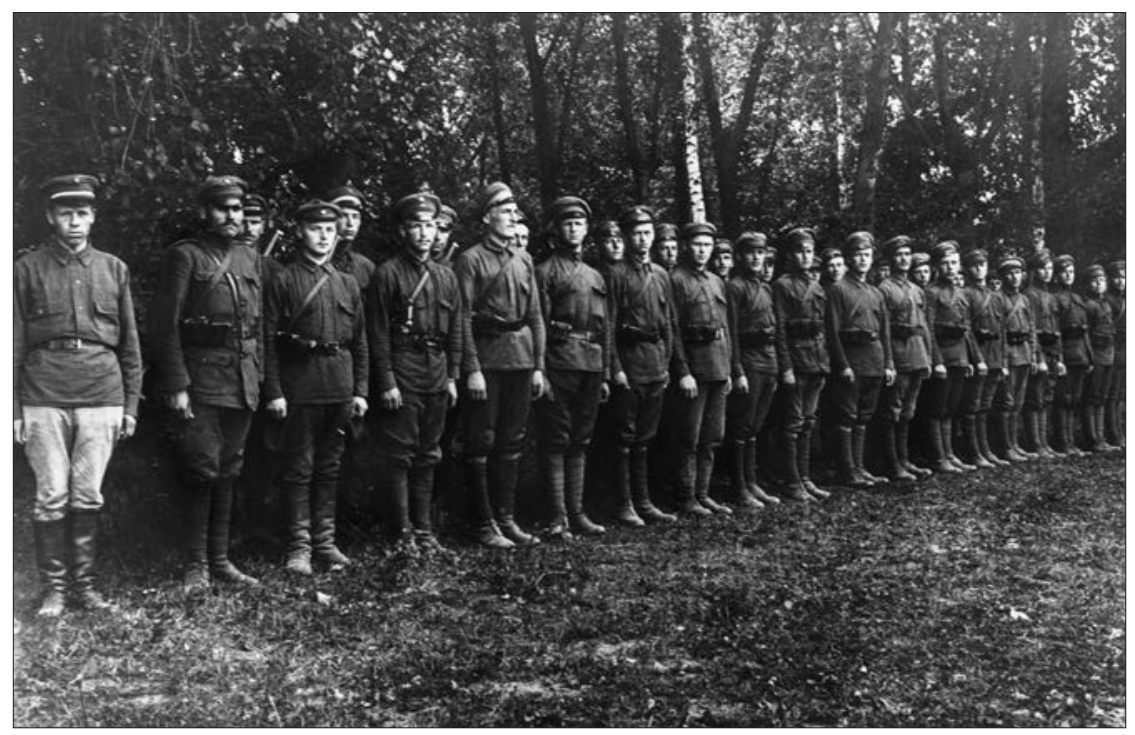

Karo policijos mokyklos būrio karių rikiuotè. Apie $1925 \mathrm{~m}$. Karo policijos mokyklos kariai dèvi 1920 m. modelio lietuvišką uniformą (Krašto apsauga, 2009, Nr. 5, p. 10)

riuomenès uniformą, buvo patvirtintas ir karo policininkų skiriamasis Ženklas - akselbantas ${ }^{149}$. Žalios spalvos iš vienos pynelès su metaliniu galu akselbantas buvo segamas ant kairiojo peties ir antros iš viršaus munduro sagos ${ }^{150}$. Jị karo policininkai, kaip tarnybos ženklą, privalèjo segèti tik tarnybos metu, t. y. patruliuodami ${ }^{151}$. Patruliuojančių karo policininkų ekipuotę sudarè kepurè, munduras ar milinė, kelnès, sukišamos ị batus, marškiniai, diržas, ginkluotę - šautuvas ir šovinine ${ }^{152}$. Paprastai tarnyboje kariai turejo būti ginkluoti pistoletais arba šautuvais ${ }^{153}$.

\footnotetext{
${ }^{149}$ Akselbantas - pinta iš juostelių perpeté, Karybos žodynas, red. A. Mackevičienè, p. 190. ${ }^{150}$ Isakymas kariuomenei Nr. 6/7, 1931 m. sausio $28 \mathrm{~d}$.

${ }^{151} 1936$ m. birželio 16 d. laikinoji Karo policijos mokyklos žandarams instrukcija, LCVA, f. 1471, ap. 1, b. 10, l. 26.

${ }^{152} 1936 \mathrm{~m}$. sausio $8 \mathrm{~d}$. žinios apie kareivio aprangos svorị per ịvairius pratimus, ten pat, b. $21,1.6$.

${ }^{153} 1936$ m. birželio 16 d. laikinoji Karo policijos mokyklos žandarams instrukcija, ten pat, b. 10, 1. 26 .
} 


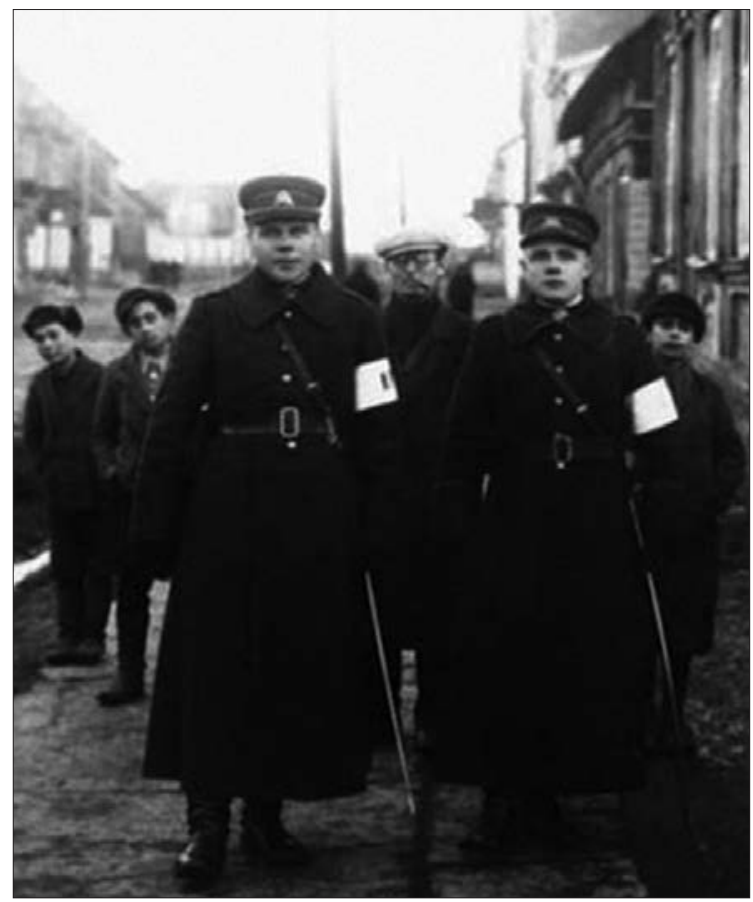

Karo policijos patruliai

Tauragès gatveje.

Tauragè, XX a. 4-asis

dešimtmetis (Krašto ap-

sauga, 2009, Nr. 5, p. 10)

1938 m. KPM lauko postų sargybiniams buvo pagamintas bandomasis žieminis apavas - klumpès su mediniais padais. Sargybiniai turèjo išbandyti šią avalynę ir îvertinti, ar yra tinkama kariuomenei ${ }^{154}$. Koks buvo tolesnis šio apavo likimas, nèra žinoma. KPM karių lauko žygio uniformą sudarẻ šalmas, munduras (žiemą - milinè), marškiniai, kelnès, sukišamos ị batus ${ }^{155}$, o ekipuotę $e^{156}$ - gertuvè, kabinama prie kuprinès, kastuvèlis, šovininè su perpetès diržu, lengvasis kulkosvaidis ir jo atsarginès dalys (dedamos į kuprinę).

${ }^{154} 1938$ m. sausio 4 d. Kauno miesto ir apskrities komendantūros ūkio viršininko raštas Karo policijos mokyklos viršininkui dèl klumpių lauko sargybiniams, ten pat, b. 63, 1. 103. 1551936 m. sausio 8 d. žinios apie kareivio aprangos svorị per ịvairius pratimus, ten pat, b. $21,1.6$.

${ }^{156}$ Ekipuote - individualus kario inventorius, kurị sudaro ginklas ir kario asmeniniai daiktai (kuprinè, šalmas, diržai, dètuvės), dujokaukè, odos apsaugos priemonès ir kt., Enciklopedinis karybos žodynas, red. Z. Kulys, p. 136. 


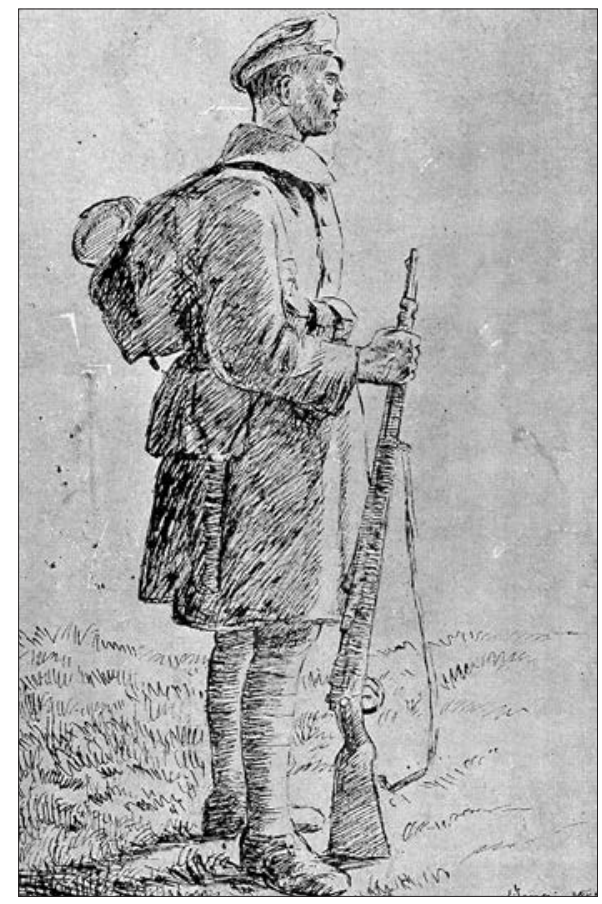

Karo milicijos mokyklos kareivio ginkluotè ir ekipuotè $1920 \mathrm{~m}$.

Karo policijos mokyklos kareivis, ginkluotas vokišku šautuvu „Mauser $98^{\text {“ }}$ (Kauno karo komendantūra 1919-1929, red. P. Jurgelevičius, p. 51)

Netelpantys ị šovininę šoviniai buvo dedami ị kišenes. Individualius daiktus kareiviai galejjo nešiotis viršutinio drabužio kišenejje ${ }^{157}$. Šaudymo pratybų, kurios vykdavo vasarą, metu kareiviai dèvejjo šviesios spalvos aprangą (kelnes ir marškinius, sujuostus diržu, prie kurio buvo kabinamos šovinių dètuvès) ir tamsios spalvos kepures ${ }^{158}$. Reikètų pažymèti, kad XX a. 3-iojo dešimtmečio pradžioje KPM kariai per pratybas dar neturejo šalmų. Jie pradèti naudoti tik to dešimtmečio pabaigoje. Gimnastikos pratybų metu KPM karių apranga buvo marškiniai ir kelnès ${ }^{159}$. Vasarą gim-

\footnotetext{
${ }^{157} 1933$ m. sausio 18 d. Karo policijos mokyklos viršininko raportas Kauno miesto ir apskrities komendantui, LCVA, f. 1471, ap. 1, b. 1, 1. 21-21ap.

${ }^{158}$ Karo policijos mokyklos kareivių šaudymo pratybos. XX a. 3-ias dešimtmetis, Kauno karo komendantūra 1919-1929, red. P. Jurgelevičius, p. 49.

${ }^{159} 1936 \mathrm{~m}$. sausio $8 \mathrm{~d}$. žinios apie kareivio aprangos svorị per įvairius pratimus, LCVA, $\mathrm{f}$. 1471, ap. 1, b. 21, 1. 6 .
} 


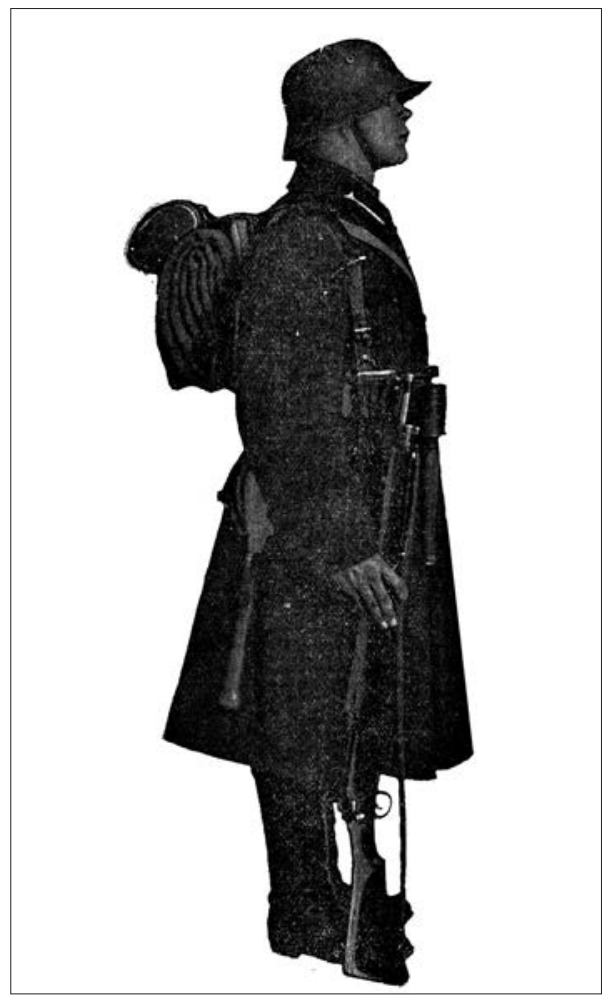

Karo milicijos mokyklos kareivio ginkluotè ir ekipuotè. Apie 1930 m. Karo policijos mokyklos kareivis, ginkluotas britišku šautuvu „Ross-Enfield M-14“ (Kauno karo komendantūra 1919-1929, red. P. Jurgelevičius, p. 51)

nastikos pratimus kareiviai atlikdavo mūvèdami ne ilgomis, o trumpomis kelnèmis ir avėdami trumpaauliais batais ${ }^{160}$. KPM kariai buvo ginkluoti šautuvais, durtuvais, turèjo nedidelę kuprinę. Mokyklos ịkūrimo pradžioje kariai buvo ginkluoti vokiškais $1898 \mathrm{~m}$. modelio „Mauser“ šautuvais, 1924 m. - Italijoje įsigytais ${ }^{161}$ britiškais „Ross-Enfield M-14“ šautuvais.

KPM kariai buvo aprūpinami nuolatinio naudojimo daiktais. Jiems buvo išduodama: kepurè su kokarda, pošalmis, šalmas, dvi milinès, du diržai su sagtimis, pora batų, marškiniai, apatinės ir viršutinès kelnès, du mundurai, autai, dvi poros pirštinių, du rankšluosčiai, čiužinys ir pata-

${ }^{160}$ Karo policijos mokyklos kareivių rytinè gimnastika prie mokyklos kareivinių, Kauno karo komendantūra 1919-1929, red. P. Jurgelevičius, p. 45.

${ }^{161}$ J. Vaičenonis, Lietuvos karių uniformos ir lengvieji ginklai XX amžiuje, p. 94. 
lynės komplektas, antsiuvas („Gediminaičiu stulpai“), kuprinė, dirželiai, šovininė, gertuvè, katiliukas, šaukštas ir šakutè, puodelis, kastuvèlis, žiemą - kailiniai be rankovių ${ }^{162}$. KPM kariai buvo aprūpinami standartine kariuomenès apranga. Tačiau KPM buvo komplektuojama išskirtinai iš aukšto ūgio vyrų, todèl ši apranga ne visada tikdavo. $179-189 \mathrm{~cm}$ ūgio kariams dažniausiai standartinès milinès būdavo per trumpos ir ankštos, todèl KPM ūkio dalies prižiūrètojo buvo reikalaujama specialiai jiems siūti ilgesnes ir platesnes milines ${ }^{163}$.

Individualios karo milicininkų uniformos projektas buvo parengtas, tačiau nepatvirtintas, todèl Karo policijos mokyklos karių uniformos nesiskyrė nuo nustatytos pėstininkų uniformos, išskirtinis buvo tik skiriamasis tarnybos ženklas. Iš pradžių mokyklos kariai dèvejjo amerikietišką uniformą su lietuviškais skiriamaisiais ženklais, o nuo XX a. 3-iojo dešimtmečio vidurio - lietuviško modelio uniformą. Mokyklos karių ekipuote taip pat nebuvo išskirtiné, komplektuojama pagal bendrus péstininkų aprangos reikalavimus, tačiau ginkluotė - specialiai karo policijos tarnybai atlikti. Karių aprūpinimas nuolatinio naudojimo daiktais atitiko kariuomenés péstininkų aprūpinimo reikalavimus, kadangi kariai gaudavo visus reikalingiausius daiktus, kad galètų tinkamai atlikti tarnybą.

\section{KARO POLICIJOS VEIKLOS SRITYS}

Karo policijos mokyklos karių tarnybą sudarè ịvairios pareigos: sargyba, patruliavimas, ikiteisminio tyrimo veiksmų atlikimas, apsauga (taip pat ir priešgaisrinè), specialiụjų užduočių vykdymas, konvojavimas ir ivairūs tarnybiniai pavedimai. Be to, kariai dalyvaudavo reikšminguose valstybiniuose ir kituose renginiuose, ịvairiai leido laisvalaikị.

\footnotetext{
162 1936-1938 m. Karo policijos mokyklos kareivių aprangos knyga, LCVA, f. 1471, ap. 1, b. $38,1.1-99$.

${ }^{163} 1938$ m. spalio 4 d. Karo policijos mokyklos viršininko raštas ùkio viršininkui dèl karių aprangos, ten pat, b. 63, 1. 302.
} 


\section{Karo policijos tarnyba}

\section{Pagrindinè tarnyba}

Karo policijos mokyklos karių tarnybos reikšmė gerai nusakyta Kauno karo komendanto plk. ltn. Kazio Skučo 1926 m. rugsejjo 2 d. karo policininkams pasakytoje kalboje: „Jūs esate karo policija, tai yra visos kariuomenès branduolys, jums tenka nešti svarbiausias ir garbingiausias pareigas, t. y. stovèti sargyboje prie Valstybės prezidento, Vyriausiojo Štabo ir t. t. Todèl visur ir visuomet turit būti drausmingi ir pačią drausmę gerai suprasti <...> "164 Dažniausiai KPM kariai èjo sargybą prie strateginių Kauno miesto objektų. Prie Kauno karo komendantūros rūmų kiekvieną dieną sargybų paskirstymą tvirtindavo karo komendantas, Kauno iguloje - jos viršininkas. Mokyklos įkūrimo pradžioje, t. y. dar 1920 m., KMM kariams priklausè trys sargybos postai prie Kauno karo komendantūros rūmų, du - prie Armijos teismo ir vienas - prie viešbučio „Metropolis“165. Tų pačių metų balandžio mẻn. mokyklos karių sargybos postai buvo panaikinti ${ }^{166} .1921 \mathrm{~m}$. birželio mèn. Kauno igulos viršininkas KMM kariams grąžino sargybos tarnybas - buvo skirti keturi sargybos postai prie Užsienio reikalų ministerijos. Tačiau jau tų pačių metų liepos mèn. KMM kariams buvo nurodyta ne tik eiti naktinę sargybą šiuose postuose, bet ir skirta aštuonių karių sargyba prie Kauno sunkiųjų darbų kalèjimo. Rugpjūčio mèn. sargybos tarnybų padaugèjo - skirta dar vienuolika sargybos postų (trims valandoms per parą) prie Valstybès archyvo, kuris buvo ịsikūręs Kauno tvirtovès 7-ajame forte ${ }^{167}$.

\footnotetext{
${ }^{164}$ Op. cit., Kazlauskas, Kauno karo sritis, Karys, 1926, Nr. 40, p. 334.

1651920 m. sausio 3 d. Kauno karo komendanto įsakymas Nr. 1/1 komendantūrai, LCVA, f. 1126 , ap. 4 , b. $219,1.1$.

${ }^{166} 1920$ m. balandžio 20 d. Kauno karo komendanto įsakymas Nr. 33/1 komendantūrai, ten pat, 1. 33; 1920 m. gegužès 23 d. Kauno karo komendanto ísakymas Nr. 61/1 komendantūrai, ten pat, 1. 61; 1920 m. lapkričio 6 d. Kauno karo komendanto i̇sakymas Nr. 312/1 komendantūrai, ten pat, b. 25, 1. 15.

${ }^{167} 1921$ m. birželio 11 d. Kauno igulos viršininko įsakymas Nr. 27/3 Kauno igulai, ten pat, ap. 2, b. 2, 1. 23; $1921 \mathrm{~m}$. liepos 27 d. Kauno ịgulos viršininko įsakymas Nr. 40/1 Kauno igulai, ten pat, 1. 28; 1921 m. rugpjūčio 13 d. Kauno igulos viršininko ịsakymas Nr. 46/1 Kauno igulai, ten pat, 1. 38ap.
} 
Nuo 1922 m. Kauno karo komendantūrai priklausẻ keturi sargybos postai: prie Krašto apsaugos ministerijos ir Prezidentūros rūmų, Kariuomenès štabo ir Kauno sunkiụjų darbų kalèjimo, ị kuriuos buvo skiriami ir KPM kariai ${ }^{168} .1930$ m. mokyklos kariams teko mažiau sargybos postų: sargybos postai liko prie Prezidentūros ir Komendantūros rūmų ${ }^{169}$. Vèliau buvo atnaujinta sargyba prie Kariuomenès štabo. 1935 m. pabaigoje KPM viršininkas paprašè Kauno miesto ir apskrities komendanto atleisti mokyklos karius nuo sargybos tarnybos prie šio štabo, motyvuodamas tuo, kad kariai nespejja įsisavinti mokomosios programos ${ }^{170}$, tačiau prašymas nebuvo patenkintas. 1938 m. Kauno ịgulos viršininko įsakymu KPM kariams papildomai buvo skirti sargybos postai prie artilerijos sandèlių Kauno tvirtovès 6-ojoje baterijoje ${ }^{171}$. Iš pateiktų duomenų matyti, kad Karo policijos mokyklos kariai sargybos tarnybą èjo prie kelių strateginių objektų. Sargyba prie Kauno komendantūros rūmų, Kariuomenès štabo, Prezidentūros rūmų, Užsienio reikalų ministerijos buvo nuolatinè, o prie Armijos teismo, viešbučio „Metropolis“, Kauno sunkiųjų darbų kalejjimo, Valstybès archyvo ir artilerijos sandèlių - laikina, nes buvo einama tik vienus dvejus metus ar keletą ménesių.

Kita svarbi tarnyba buvo budejimas kovinès parengties (nenumatytų ịvykių atveju), siejama su greitu reagavimu. Parengties daliai budèti buvo skirtas vienas mokomosios kuopos būrys, prižiūrimas karininko. Nuo $1920 \mathrm{~m}$. balandžio šis budejjimas trukdavo tris paras, po to tarnybą perimdavo Kauno karo komendantūros mokomoji komanda ${ }^{172} .1921 \mathrm{~m}$. rugsèjo mèn. budejjimas buvo sutrumpintas iki dviejų parų, vieną parą iš

\footnotetext{
${ }^{168} 1922$ m. gruodžio 7 d. Kauno igulos viršininko įsakymas Nr. 27/1 Kauno igulai, ten pat, ap. 2, b. 2, 1. 86ap; 1923 m. kovo 9 d. Kauno igulos viršininko įsakymas Nr. 3/1 Kauno igulai, ten pat, 1. 90ap-91.

1691930 m. gegužès 12 d. Kauno miesto ir apskrities komendanto įsakymas Nr. 132/1 komendantūrai, ten pat, ap. 4, b. 37, 1. 76ap.

${ }^{170} 1935$ m. gruodžio 28 d. Karo policijos mokyklos viršininko raportas Kauno miesto ir apskrities komendantui dèl sargybos postų panaikinimo, ten pat, f. 1471, ap. 1, b. 23, 1. 389. ${ }^{171} 1938$ m. lapkričio 21 d. Kauno igulos viršininko įsakymas Nr. 3/6 Kauno igulai, ten pat, f. 1126, ap. 1, b. 91, 1. 4ap.

1721920 m. balandžio 20 d. Kauno karo komendanto įsakymas Nr. 33/1 komendantūrai, ten pat, ap. 4, b. $219,1.33$.
} 
jų vykdomas kartu su Kauno karo komendantūros kuopa ${ }^{173}$. Nuo 1930 m. parengties dalies budejimo tarnyba buvo sudaroma tik iš KPM karių ${ }^{174}$. Galima teigti, kad šios tarnybos priskyrimas KPM rodè siekị turèti sutelktą kovinị būrị, kuris bet kokiomis aplinkybèmis galètų labai greitai reaguoti.

KPM kariai patruliuodavo ne tik Kauno mieste ir $10 \mathrm{~km}$ spinduliu aplink miestą, bet ir Gaižiūnų poligone. XX a. 3-iajame dešimtmetyje karo policininkai patruliuodavo ne vieni. Du trys karo policininkai patruliuodavo kartu su Kauno igulos priežiūros karininku (placadjutantu ${ }^{175}$ ), kuris padèdavo užtikrinti tvarką mieste ir viešose vietose, kur būdavo karių. Pvz., su neblaiviais kariais ar civiliais lydinčiajam karininkui kalbėtis nebuvo leidžiama, jis tik galejo duoti nurodymus KPM kariams. Karo policininkų prerogatyva buvo ịgulos sargybų tikrinimas ir karių nusižengimų aiškinimas ${ }^{176}$. Nuo $1930 \mathrm{~m}$. karo policininkai pradejo patruliuoti savarankiškai. Karinei drausmei ir viešajai tvarkai iguloje palaikyti, be priežiūros karininko, buvo skiriami patruliuoti du karo policininkai puskarininkiai. Jie turejjo užtikrinti karinę drausmę, stebėti, kaip laikomasi uniformos dèvejjimo taisyklių, atlikti karių asmens dokumentų patikras. Karius, pažeidusius viešąją tvarką (nepadoriai besielgiančius, neblaivius, neturinčius leidimo išeiti iš kareivinių ir kitaip nusižengusius karo policininkai sulaikydavo ir pristatydavo ì Kauno igulą budètojui arba ị sulaikytojo karinị dalinị ${ }^{177} .1936 \mathrm{~m}$. buvo išplèstos Karo policijos mokyklos patrulių teisès ir pareigos. Visos ankstesnès karo policijos patrulių pareigos ir teisès liko, tačiau atsirado papildomų pareigų: stebèti civilius, kurie stengiasi užmegzti pažintis su kariais, taip pat įtartinus asmenis, kurių dokumentai gali būti patikrinti, o jie patys sulaikyti, užtikrinti, kad prie kareivinių nesirinktų pašaliniai. Tačiau KPM patruliai neturejjo teisès spręsti karių

${ }^{173} 1921$ m. rugsèjo 1 d. Kauno karo komendanto įsakymas Nr. 245/1 komendantūrai, ten pat, b. $28,1.1$.

${ }^{174} 1930$ m. gegužès 12 d. Kauno miesto ir apskrities komendanto ịsakymas Nr. 132/1 komendantūrai, ten pat, b. 37, 1. 76ap.

${ }^{175}$ Placadjutantas - karininkas prie Kauno igulos viršininko, prižiūrejjęs karinę tvarką Kauno mieste ir apylinkèse.

${ }^{176} 1922$ m. instrukcijos Kauno igulos placadjutantui, ten pat, ap. 2, b. 222, 1. 8-9.

${ }^{177} 1934 \mathrm{~m}$. balandžio 17 d. Kauno igulos viršininko įsakymas Nr. 7/3 Kauno igulai, ten pat, f. 1471, ap. 1, b. 12, 1. 7-7ap. 
ir civilių konfliktų - privalëjo kviesti viešają policiją. Civilių konfliktų ar riaušių atveju galejo tik padèti viešajai policijai, jeigu to buvo prašomi ${ }^{178}$.

Tais pačiais metais igulos viršininkas papildomai skyrẻ patrulių tvarkai mieste palaikyti jau nustatęs jų patruliavimo ribas: KPM ir 1-ojo husarų Lietuvos didžiojo etmono kunigaikščio Jonušo Radvilos pulko patruliams priklausė Žaliakalnio mikrorajonas - čia patruliuoti buvo paskirti keturi mokyklos kariai (vienas puskarininkis ir trys eiliniai), aprūpinti transporto priemone - sunkvežimiu ${ }^{179}$. Pažymètina, kad 1931 m., ịkūrus Gaižiūnų poligoną, ì pastarąji karo policijos patruliai buvo komandiruojami. Čia KPM kariai prižiūrèjo turtą, šulinius, maudyklas, kelius, tiltus, telefono linijas, šaudymo zonas, kontroliuodavo, kad ị jas nepatektų civilių ar karių, raportuodavo poligono komendantui apie atvykstančius ị poligoną žmones. Poligone atliekantys tarnybą karo policininkai buvo pavaldūs poligono komendantui (jam pranešdavo apie visus ịvykius), o grižę i mokyklos teritoriją - KPM viršininkui ${ }^{180}$. Tenka konstatuoti, kad karo policininkų patrulių funkcijos (mieste - karinès drausmès priežiūra ir nusikaltimų prevencija, o poligone - saugumo užtikrinimas ir karinio turto apsauga) buvo pagrịstos teisètvarkos institucijoms keliamais saugumo ir tvarkos reikalavimais.

I KPM karių tarnybą i̇ejo ir ikiteisminio tyrimo veiksmai - kvotos ${ }^{181}$, kurios buvo atliekamos ịtarus bet kokị karių nusikaltimą ${ }^{182}$. Karininkai turejjo kvotas atlikti tuomet, kai kariai nusižengdavo karinei drausmei ir kariuomenès įstatymams, kai jie nusižengdavo karinejje teritorijoje ar at-

\footnotetext{
${ }^{178} 1936$ m. birželio 16 d. laikinoji Karo policijos mokyklos žandarams instrukcija, ten pat, b. 10, 1. 26-26ap.

${ }^{179} 1936$ m. birželio 18 d. Kauno igulos viršininko įsakymas Nr. 12/1 Kauno igulai, ten pat, b. 29, 1. 12 .

${ }^{180} 1936$ m. birželio 16 d. laikinoji Karo policijos mokyklos žandarams instrukcija, ten pat, b. 10, 1. 26ap.

${ }^{181}$ Kvota - pirmoji ikiteisminio tyrimo etapo dalis, kurios metu siekiama išsiaiškinti nusikalstamos veikos aplinkybes, nustatyti, ar kaltinamąji reikia traukti baudžiamojon atsakomybėn ir perduoti teismo tardytojui. Pareigūnas, atlikęs kvotą, perduoda medžiagą teismui, pats išvadų nedaro (karo policijos kariai - Karo policijos mokyklos viršininkui, kuris turèjo nuspręsti, ar reikia tęsti bylą): P. Ancelis, Baudžiamojo proceso ikiteisminis etapas, Vilnius, 2007, p. 36.

${ }^{182}$ Kas reikia žinoti apie kvotas, Kardas, 1929, Nr. 11, p. 171.
} 
likdami tarnybines pareigas, kai tai būdavo civilių padaryti nusižengimai karinejje teritorijoje ${ }^{183}$. Kvotas atlikti skirdavo mokyklos viršininkas. Jis dažniausiai tai padaryti pavesdavo leitenantams. Skiriant kvotèjus turèjo būti atsižvelgta ị ístatymų keliamus reikalavimus, t. y. kad jie būtų netraukti baudžiamojon atsakomybẻn, aukštesnio laipsnio arba eitų aukštesnes pareigas už kvočiamus asmenis ir nešališki ${ }^{184}$. Dažniausiai jaunesnieji mokyklos karininkai atlikdavo kvotas dèl karių padarytų nusikaltimų (kai dingdavo pinigai, daiktai ir pan.), drausminių nusižengimų (pasišalinimo iš tarnybos vietos, alkoholinių gèrimų vartojimo tarnybos metu ir pan.) ${ }^{185}$. KPM viršininkas ir pats atlikdavo kvotas dèl karių ir civilių nusikaltimų ${ }^{186}$. Pažymètina, kad KPM veikla, atskleidžiant nusikaltimus ir kitus nusižengimus, buvo susijusi su teisètvarkos igyvendinimu kariuomenèje.

\section{Apsaugos tarnyba}

Nuolatinėms KPM karių tarnyboms buvo skiriama daugiausia laiko. Be jų, mokyklos kariams tekdavo eiti ir kitokio pobūdžio apsaugos pareigas. Pvz., 1920 m. Latvijos ir Lietuvos pasienyje vyko JAV, Didžiosios Britanijos ir Prancūzijos karinès misijos atstovų ir latvių derybos dèl sienų nustatymo. Taikos misijos atstovai kartu su Kauno karo komendantūros apsauga iš Kauno nuvyko ị pasieni prie Mažeikių, kur vyko šios derybos. Misijos apsaugai užtikrinti buvo skirti du KMM kariai. Jie misijos atstovus saugojo visą laiką, t. y. dvi dienas ${ }^{187}$. Nuo 1937 m. KPM kariai buvo komandiruojami ị Ukmergès rajone esančią Respublikos Prezidento vasaros

\footnotetext{
${ }^{183}$ J. D., Policija ir karių nusikaltimai, Policija, 1924, Nr. 4, p. 7-8.

${ }^{184}$ A. Zarinas, Kvota karo baudžiamajame procese, Mūsǔ žinynas, 1927, Nr. 36, p. 294.

${ }^{185} 1939$ m. rugpjūčio 1 d. Karo policijos mokyklos j. ltn. Jono Remeikio raportas mokyklos viršininkui dèl atliktos kvotos, $L C V A$, f. 1126, ap. 4, b. 329, 1. 222; 1940 m. balandžio 6 d. Karo policijos mokyklos viršininko raportas Kauno miesto ir apskrities komendantui apie kvotos atlikimą, ten pat, f. 1471, ap. 1, b. 114, 1. 139; 1940 m. birželio 11 d. Karo policijos mokyklos j. ltn. J. Samuolio atlikta kvota, ten pat, 1. 203.

${ }^{186} 1938 \mathrm{~m}$. balandžio $15 \mathrm{~d}$. Karo policijos mokyklos viršininko raportas Kauno miesto policijos 6-osios nuovados viršininkui dèl asmenų šaukimo ị mokyklą kvotoms, ten pat, b. $63,1.114$.

${ }^{187}$ J. Demereckis, Savanorio ir kontržvalgybininko atsiminimai, p. 48-49.
} 
rezidenciją apsaugai užtikrinti. Dar $1934 \mathrm{~m}$. valstybès vadovas 60-mečio proga gavo dovanų ūkị savo tèviškèje, Ukmergès rajone, - Užugirio dvarą, jame $1937 \mathrm{~m}$. vasarą atostogavo pirmą kartą ${ }^{188}$. Rezidenciją saugojo KPM komanda, sudaryta iš 32 karių, jiems vadovavo j. ltn. Stasys Markauskas. I šią komandą buvo paskirti ir 2 Ryšių bataliono kareiviai. Iš viso apsaugos komandoje buvo 4 puskarininkiai, 17 grandinių, 11 KPM eilinių, 1 Ryšių bataliono grandinis ir 1 eilinis ${ }^{189}$. Šios komandos komandiruote truko apie mènesi - tiek, kiek atostogavo Respublikos Prezidentas. Apie 30 karo policininkų buvo skiriami atostogaujančio Palangoje Prezidento apsaugai ${ }^{190}$.

Be reikšmingų asmenų apsaugos, Karo policijos mokyklos kariai vykdè ir priešgaisrinès apsaugos tarnybos funkcijas. Kaip minèta, $1931 \mathrm{~m}$. mokykloje buvo ịsteigta neetatinė ugniagesių komanda. Be ịprastinès tarnybos, ji dalyvaudavo ne tik priešgaisrinès apsaugos mokymuose, bet ir mokomosiose priešgaisrinès apsaugos pratybose - paskelbus bandomąji gaisro aliarmą ir praktiškai gesindama gaisrus ${ }^{191}$. Kauno igulos kariuomenès dalių ir ịstaigų ugniagesių komandos buvo suskirstytos pagal penkis veikimo rajonus: 1-ajam rajonui priklausè 2-ojo pèstininku Lietuvos didžiojo kunigaikščio Algirdo ir 3-iojo artilerijos pulkų, Ryšių ir Pionierių batalionų, Autorinktinès ugniagesių komandos, 2-ajam - 5-ojo pėstininkų Lietuvos didžiojo kunigaikščio Kęstučio pulko ir Atskirosios artilerijos grupès, 3-iajam - Aviacijos ir Šarvuočių rinktinès, 4-ajam - Karo policijos mokyklos ir 1-ojo husarų Lietuvos didžiojo etmono kunigaikščio Jonušo Radvilos pulko komandos, 5-ajam - Karo muziejaus ir Karo kalejjimo drausmès dalių ugniagesių komandos ${ }^{192}$. Nuo $1931 \mathrm{~m}$. birželio 15 d. iki 1935 m. birželio 14 d. Karo policijos mokyklos ugniagesiai gesinti gaisrų buvo iškviesti 25 kartus. Iškvietimų skaičius nedidelis, atsižvelgiant $\mathfrak{i}$ tai, kad minètu laikotarpiu Kauno igulos kariuomenès dalių ugniagesiai gavo

\footnotetext{
${ }^{188}$ V. Šliogeris, Antanas Smetona. Žmogus ir valstybininkas, Klivlendas, 1966, p. 94, 96. 1891937 m. liepos 4 d. Kauno miesto ir apskrities komendanto iqsakymas Nr. 185/3 komendantūrai, LCVA, f. 1471, ap. 1, b. 42, 1. 189.

${ }^{190}$ J. Girenis, Karių gyvenimas Palangoje, Karys, 1934, Nr. 34, p. 690; V. Statkus, Lietuvos ginkluotos pajégos 1918-1940, p. 424.

${ }^{191}$ Isakymas kariuomenei Nr. 49/1-14, 1928 m. birželio 15 d.; ten pat, Nr. 84/1-13, 1933 m. lapkričio $15 \mathrm{~d}$.

1921933 m. lapkričio 10 d. Kauno igulos viršininko įsakymas Nr. 26/1 Kauno igulai, LCVA, f. 1126, ap. 2, b. 33, 1. 66.
} 
344 iškvietimus dèl gaisro ${ }^{193}$. KPM ugniagesių komanda pirmiausiai buvo kviečiama gaisrų gesinti priskirtame rajone, o i kitas miesto dalis - kilus didesnių gaisrų. Iš didesnių gaisrų, kuriuos padejo gesinti mokyklos ugniagesiai, galima paminèti $1932 \mathrm{~m}$. birželio $15 \mathrm{~d}$. Vidūno alèjoje Kaune kilusị gaisrą. Jị gesinant buvo sužeisti ir du KPM ugniagesiai ${ }^{194} .1935 \mathrm{~m}$. liepos $2 \mathrm{~d}$. buvo kilęs didelis gaisras lentpjūvèje Kęstučio gatvejje, ji gesinant dalyvavo 185 kariuomenès ugniagesiai, tarp jų ir 26 KPM kariai ${ }^{195}$.

1937 m. spalio 9 d. mokyklos ugniagesiams kartu su 1-ojo husarų Lietuvos didžiojo etmono kunigaikščio Jonušo Radvilos pulko ir miesto ugniagesių komandomis teko gesinti gaisrą, kilusį gyvenamųjų namų kvartale Moniuškos gatvejje ${ }^{196} .1938$ m. gegužès $14 \mathrm{~d}$. buvo kilęs ypač didelis gaisras Kleboniškio miške, už Kauno igulos Eigulių šaudyklos. Ji pastebejo tuo metu šaudykloje pratimus darę karo policininkai, jie pirmieji ir èmèsi gesinimo veiksmų. Nepavykus užgesinti ugnies, buvo atsiųstos KPM, 1-ojo husarų Lietuvos didžiojo etmono kunigaikščio Jonušo Radvilos pulko, Inžinerijos bataliono, Kauno miesto savivaldybès, Raitojo policijos rezervo ir savanorių ugniagesių komandos ${ }^{197} .1939$ m. liepos 4 d. KPM kariams teko gesinti panašaus dydžio gaisrą, kilusị Prienų urèdijos miške. Ši gaisrą gesinant dalyvavo ne tik KPM ugniagesiai, bet ir kariai, kurie tik kasè griovius, kad atskirtų degantị plotą, taip pat Prienų iggulos ugniagesiai ${ }^{198}$. Iš pateiktų duomenų matyti, kad tokiais atvejais dalyvaudavo ne tik specialiai to mokyti Karo policijos mokyklos ugniagesiai, bet ir kiti jos kariai.

Kalbant apie priešgaisrinès apsaugą pažymètina, kad KPM ugniagesiai ją užtikrino ne tik mokyklos teritorijoje, bet ir Karo muziejuje. Jie čia buvo skiriami budèti tris paras per mènesi $i^{199}$. Tam tikrais atvejais KPM ugniagesių komandai tekdavo sustiprinti priešgaisrinę apsaugą.

\footnotetext{
${ }^{193}$ V. Baltrimas, Ugniagesyba ir kariuomenè, Ugniagesys, 1936, Nr. 9, p. 31.

${ }^{194}$ Kariuomenès ugniagesiai, Lietuvos gaisrininkas, 1932, Nr. 8, p. 14.

${ }^{195} 1935$ m. liepos 2 d. pranešimas apie gaisrą lentpjūvèje, LCVA, f. 1471, ap. 1, b. 24, 1. 12.

${ }^{196}$ Kariuomenès ugniagesiai, Karys, 1937, Nr. 42, p. 1202.

${ }^{197}$ Kariuomenès ugniagesiai, ten pat, 1938, Nr. 20, p. 594.

198 Gaisrų fronte, ten pat, 1939, Nr. 30, p. 898.

1991931 m. spalio 2 d. Kauno igulos viršininko raštas Karo policijos mokyklos viršininkui dèl mokyklos ugniagesių komandos skyrimo ị budejimą Karo muziejuje, LCVA, f. 1471, ap. 1, b. $5,1.20$.
} 
Pvz., 1934 m. birželio 28-liepos 1 d. Kauno mieste vykusio eucharistinio kongreso ${ }^{200}$ metu buvo sustiprinta beveik visų kariuomenès ir miesto ugniagesių komandų priešgaisrinè apsauga ir parengtis. KPM kareivinèse 200 kongreso dalyvių buvo skirta nakvynè, todèl šios patalpos buvo aprūpintos papildomomis gesinimo priemonėmis ir numatytas mokyklos ugniagesių budejimas ${ }^{201}$. Kilus gaisro pavojui, mokyklos teritorijoje ugniagesiai ir kariai privalèjo vadovautis ugniagesių komandos viršininko nustatytomis taisyklemis ${ }^{202}$. Galima teigti, kad Karo policijos mokykloje priešgaisrinè apsauga buvo vykdoma tinkamai, kadangi dokumentuose neužfiksuota nè vieno gaisro atvejo jos teritorijoje.

Kitos KPM karių apsaugos tarnybos nebuvo itin reikšmingos. Pvz., 1934 m. Parodos aikšteje Kaune vykusioje mokyklų ekskursijų stovyklos apsaugoje buvo ir KPM karių. Jie saugojo dalyvius ir prižiūrejjo tvarką stovykloje, kurioje buvo apsistoję mokiniai ${ }^{203}$. KPM teko atlikti ir garbės sargybos funkcijas. $1934 \mathrm{~m}$. gegužès $23 \mathrm{~d}$. KPM karių garbès sargyba prie Prezidentūros rūmų dalyvavo Belgijos karaliaus delegacijos priëmime ${ }^{204}$ ir 1937 m. birželio 14 d. Japonijos igaliotojo ministro skiriamųjų raštų Respublikos Prezidentui įteikimo iškilmingoje ceremonijoje. Garbès sargyba buvo sudaryta iš KPM karių - karininko ir 54 kareivių. Mokyklos viršininkas ị sargybą skyrẻ 1-osios kuopos kareivius, o jų viršininku - ltn. Justiną Samuolị. Sargyba stovejo prie Prezidentūros rūmų ${ }^{205}$. Pažymètina,

\footnotetext{
${ }^{200}$ Eucharistinis kongresas - katalikų dvasininkų organizuojamos iškilmès, skirtos tikinčiųjų bendruomenei suartinti. 1934 m. birželio 28-liepos 1 d., kongreso metu, ì Kauną atvyko kelios dešimtys tūkstančių dalyvių: 100000 žmonių suplauks ị Kauną eucharistinio kongreso proga, Diena, 1934, Nr. 25, p. 1.

${ }^{201} 1934$ m. birželio 20 d. Kauno igulos viršininko įsakymas Nr. 2/1-7 Kauno ugniagesių komandoms, LCVA, f. 1471, ap. 1, b. 5, 1. 90.

2021935 m. liepos 9 d. Karo policijos mokyklos instrukcija gaisrui gesinti, ten pat, b. 6, l. 4ap-5.

${ }^{203} 1934$ m. gegužès 2 d. Vyriausiojo štabo Spaudos ir švietimo skyriaus viršininko raportas Kauno miesto ir apskrities komendantui dẻl karo policininko paskyrimo tvarkos palaikymui, ten pat, b. 14, 1. 111.

${ }^{204} 1934$ m. gegužès 22 d. Generalinio štabo valdybos skyriaus viršininko telefonograma Kauno miesto ir apskrities komendantui dèl užsienio delegacijos atvykimo iškilmių, ten pat, l. 130.

${ }^{205} 1937$ m. birželio 3 d. Kariuomenès štabo viršininko raštas Kauno miesto ir apskrities komendantui dèl garbès sargybos sudèties, ten pat, b. 47, l. 119.
} 
kad KPM karių apsaugos tarnybos pareigos buvo reikšmingiausios tada, kai buvo saugomi svarbūs asmenys, ypač Prezidentas, taip pat užtikrinama karinio turto priešgaisrinè sauga.

\section{Specialiosios užduotys}

KPM kariams teko atlikti specialiąsias užduotis $1920 \mathrm{~m}$. vasario 21-23 d. Kauno igulos kareivių, 1923 m. sausio 10-15 d. Klaipėdos sukilimų ir 1926 m. gruodžio $17 \mathrm{~d}$. perversmo metu.

Pirmiausia reikètų aptarti Kauno ịvykius, kai kariai, išprovokuoti i kariuomenès dalinius ịsiskverbusių bolševikų, lenkų ir vokiečių agitatorių, buvo sukilę prieš valdžią, aštriai kèlè maisto davinio pagerinimo ir kitus klausimus ${ }^{206}$. Prie sukilimo buvo prisideję beveik visi Kauno igulos daliniai, išskyrus Karo ir Karo milicijos mokyklas. Sukilimo metu KMM kariams buvo pavesta saugoti bankus, tiltus (Aleksoto), atstovybes, dieną ir naktị patruliuoti mieste. Kadangi naktị buvo draudžiama vaikščioti be leidimų, patruliai turèjo tikrinti visų sutiktųjų asmens dokumentus. Jau pirmąją sukilimo naktị du mokyklos kareiviai sulaikė iš Artilerijos pulko, dislokuoto Panemunèje, kareivinių pabėgusị kareivị. Jis buvo pristatytas ị Kauno karo komendantūrą. Jis karininkams suteike žinių apie savo dalinio padètị ir taip padejo pasirengti malšinti sukilimą. Antrosios sukilimo dienos rytą, gavus žinių, kad 1-ajame raitelių pulke nevyksta užsièmimai, KMM kareiviui Jonui Demereckiui buvo įsakyta minètame pulke atlikti žvalgybą ir ištirti tenykštę padètị. Pastarajai užduočiai atlikti buvo duoti specialūs nurodymai: kareivis turejjo neišsiduoti ir prisistatyti esantis iš dalinio, dislokuoto Šančiuose, paskleisti dezinformaciją, kad Šančių daliniuose sukilimas jau baigèsi. Ši avantiūra pavyko. Pasipriešinimas 1-ajame raitelių pulke buvo užgniaužtas, nes tą pačią dieną, dar prieš pietus, buvo pranešta Kauno karo komendantūrai, kad pulko kariai nutraukè sukilimą ir išèjo ị užsièmimus ${ }^{207}$.

\footnotetext{
${ }^{206}$ J. Jurginis, Kauno igulos kareiviu sukilimas 1920 metais, Vilnius, 1955, p. 1-3; Bandymas sukilti Kauno iguloj, Kariškių žodis, 1920, Nr. 9, p. 65-66; Dar šis tas apie riaušes, ten pat, 1920, Nr. 10, p. 74.

${ }^{207}$ J. Demereckis, Savanorio ir kontržvalgybininko atsiminimai, p. 36-40.
} 
KMM kariai suvaidino reikšmingą vaidmenị ir likviduojant sukilimo židini aviacijos daliniuose, kadangi šios dalies kariai ant Aleksoto tilto buvo pastatyti kaip sargybiniai. Jie neleido pereiti ị Aleksoto pusę. KMM kariams buvo ịsakyta atlikti aviacijos dalinių apsupimo operaciją. Kariai buvo išrikiuoti dviejų būrių eile nuo Kanto g. iki Neries upès. Perèję Nemuną ledu, būriai apsupo sukilèlius ir šie po nedidelio susirèmimo pasidavé2 ${ }^{208}$. Pažymètina, kad KMM pademonstravo gerą karinị pasirengimą, nors karių mokymai buvo prasidèję tik prieš du mènesius.

Karo milicijos mokyklos kariais pasiremta ir 1923 m. Klaipėdos krašto sukilimo metu. Dar 1922 m. gruodžio mèn. buvo parengtas išsamus sukilimo planas, kviečiami savanoriai iš Klaipėdos krašto, ir jų susirinko apie 300. Toks nedidelis savanorių skaičius kèlè nerimą karinei vadovybei, todèl ji nusprendè ị pagalbą pasitelkti reguliariosios kariuomenès dalinius ir šaulius. Šie daliniai buvo išsiųsti slapta, perrengti civiliniais drabužiai slepiant, kad sukilime dalyvauja kariuomenè ${ }^{209}$. Iš reguliariosios kariuomenès buvo atsiųsta apie 600 karių: 5-ojo pėstininkų Lietuvos didžiojo kunigaikščio Kęstučio, 8-ojo pėstininkų Kauno kunigaikščio Vaidoto, 1-ojo husarų pulkų, Karo ir Karo milicijos mokyklų kariai. 1923 m. sausio pradžioje buvo sudarytas kovinis dalinys - Ypatingosios paskirties rinktiné $\dot{2}^{210}$. I ją buvo paskirti KMM 5 karininkai ir 130 karių. Rinktinė buvo padalyta ị tris grupes: Klaipėdos, Pagègių ir Šilutès. Karo milicijos mokyklos kariai priklausè Klaipėdos grupès 3-iajai kuopai ${ }^{211}$. Kovos dèl Klaipėdos prasidejo 1923 m. sausio 10 d. Per kelias sukilimo dienas Klaipėdos kraštas buvo užimtas sukilèlių. Kovose žuvo 12 lietuvių karių, tarp jų ir Karo milicijos mokyklos 2-osios kuopos grand. Juozas Vilkas (sausio 13 d.) $)^{212}$.

\footnotetext{
${ }^{208}$ Ten pat, p. 40-41.

${ }^{209}$ P. Žostautaitè, Klaipédos kraštas 1923-1939, p. 25-27.

${ }^{210}$ V. Vareikis, Klaipeda XX amžiuje, p. 25-26.

${ }^{211} 1923$ m. sausio 8 d. rinktinès vado J. Budrio (J. Polovinsko) ir štabo viršininko Okso (J. Tomkaus) įsakymas Nr. 1 Ypatingo paskyrimo rinktinei; Z. Genienè, J. Žukas, Kova dèl Klaipédos. 1923-ieji, Klaipèda, 2003, p. 87-90.

${ }^{212} \mathrm{P}$. Žostautaite pateikia informaciją, kad vienas iš žuvusiųjų Klaipėdos sukilime (Vincas Vilkas) buvo Milicijos mokyklos kursantas. Palyginus informaciją ir archyvinị dokumentą (1939 m. kovo 9 d. Karo policijos mokyklos viršininko raportą Kauno miesto ir apskrities komendantui dèl žuvusių karių pagerbimo, LCVA, f. 1471, ap. 1, b. 93, 1. 103), nustatyta, kad tai buvo Karo milicijos mokyklos 2-osios kuopos grand. Juozas Vilkas.
} 
Žuvusiojo atminimas vèliau buvo pagerbtas mokyklos karių ${ }^{213}$.

Kitas svarbus istorinis ịvykis, kurio kontekste reikètų paminėti KPM karius, buvo $1926 \mathrm{~m}$. gruodžio $17 \mathrm{~d}$. perversmas. Prie rengiamo perversmo neprisidejo KPM kariai, kuriais bandè remtis Vyriausiojo kariuomenès štabo viršininkas plk. ltn. Kazys Škirpa ir taip pasipriešinti perversmininkams. Prasidejus perversmui, pas plk. ltn. K. Škirpą atejo karininkai, norintys ji sulaikyti, bet šiam pavyko pabėgti ${ }^{214}$ ir pasiekti KPM. Ten buvo duotas įsakymas dviem kareiviams nuvykti ị 1-ąji husarų pulką ir pranešti, kad pulko patruliai prie Igulos bažnyčios atvyktų pas plk. ltn. K. Škirpą. Tačiau duodamas šị įsakymą karininkas nežinojo, kad pulkas yra perversmininkų pusèje. Kitiems dviem mokyklos kareiviams buvo įsakyta vykti ị Šarvuočių rinktinę, kur taip pat nežinota, kad dalinys užimtas perversmininkų.

Pats Vyriausiojo kariuomenès štabo viršininkas su Karo policijos mokyklos kuopa nuvyko ị Laisvès alèją. Leisdamiesi nuo Vytauto kalno, jie sutiko du karininkus, kurie vedè suimtą KPM kuopos vadą kpt. K. Rudaitị-Rudavičių. Plk. Itn. K. Škirpos iniciatyva karininkas buvo išlaisvintas, o konvojavę jị karininkai - nuginkluoti, suimti ir nugabenti į KPM kareivines. Po to toliau buvo igyvendinamas strateginių kariuomenès pastatų užèmimo planas: kpt. K. Rudaitis-Rudavičius su būriu karių išvyko užimti Kauno karo srities rūmų, plk. ltn. K. Škirpa su dviem būriais (apie 80 karių) - Krašto apsaugos ministerijos rūmų. Šiems būriams išvykus ị paskirties vietas, dar vienas karys, stovėjęs prie plk. ltn. K. Škirpos namų, buvo suimtas ir nuvestas i KPM kareivines. Tik KPM būriams atvykus prie KAM paaiškejjo, kad rūmai jau užimti ir saugomi 2-ojo pėstininkų Lietuvos didžiojo kunigaikščio Algirdo pulko vieno iš batalionų karių ${ }^{215}$.

2131938 m. lapkričio 23 d. kariuomenès vadas Nepriklausomybès 20-mečio ir kariuomenès jubiliejaus proga įsakè visiems kariuomenès daliniams išsiaiškinti garbingai žuvusius dalinių karius ir pagerbti jų atminimą. Karo policijos mokyklos kareivinèse buvo pakabinta paminklinė balto marmuro lenta su grand. J. Vilko portretu ir užrašu. Kareivis buvo įtrauktas ị mokyklos 2-osios kuopos sąrašus ir per vakarinius patikrinimus šaukiamas bendrąja tvarka - pirmasis kareivis atsiliepdavo: „Garbingai žuvo dèl Tèvynès laisvés 1923 m. sausio 13 d. “: Itsakymas kariuomenei Nr. 81/1, 1938 m. lapkričio 23 d.; 1939 m. kovo 9 d. Karo policijos mokyklos viršininko raportas Kauno miesto ir apskrities komendantui dèl žuvusių karių pagerbimo, LCVA, f. 1471, ap. 1, b. 93, 1. 103.

214J. Švoba, Seiminè ir prezidentiné Lietuva, p. 159-160.

${ }^{215}$ K. Škirpa, Pakeliui su Mykolu Sleževičiumi, Mykolas Sleževičius, p. 260-261. 
KPM karių pajègos nesugebèjo pasipriešinti, nes visi strateginiai taškai jau buvo užimti, visur stovejjo sargybos, mieste patruliavo kariai, o ankstesnei vyriausybei ištikimi karininkai buvo suimti ${ }^{216}$. KPM kariai buvo priversti atsitraukti ir grịžti ị kareivines, tačiau sužinota, kad kareivinès užimtos 1-ojo husarų pulko, o mokyklos kariai nuginkluoti, suimtieji išlaisvinti ${ }^{217}$. Iš pateiktų pavyzdžių matyti, kad Karo policijos kariams tekdavo atlikti specialiąsias tarnybines užduotis. Karių indèlis minètų ìvykių metu buvo skirtingas, kaip ir patys įvykiai. Mokyklos kariai pateisino su karo policijos tarnyba susijusius lūkesčius, atliko savo užduotis 1920 m. Kauno igulos kareivių sukilimo metu.

\section{Tarnybiniai pavedimai ir konvojavimas}

KPM kariai atlikdavo ir kitus tarnybinius pavedimus. Pirmiausia mokyklos kariai buvo komandiruojami ị ívairias Lietuvos vietoves vykdyti skirtų užduočių. Jau pirmaisiais KMM gyvavimo mėnesiais kariams teko vykdyti tarnybines užduotis už Kauno apskrities ribų. Pvz., 1920 m. sausio mèn. jiems buvo skirta inkasavimo užduotis - parvežti ị Kauną 10 děžių su valstybine valiuta iš Kretingos banko. Užduočiai atlikti buvo skirta 12 mokyklos karių ir Kauno karo komendantūros karininkas. Tačiau nepasirūpinta transportu, todèl kariai vyko visuomeniniu transportu - traukiniu ${ }^{218}$.

KPM kariai vykdè ir 2-osios pėstininkų divizijos štabo viršininko pavestas užduotis. Pvz., gabeno ịslaptintus dokumentus ị kitų divizijos štabų būstines (1-osios Panevėžyje ir 3-iosios Šiauliuose) ${ }^{219}$, vykdè Kauno karo komendanto užduotis - lydejjo naujokus ị paskirties dalinius ${ }^{220}$.

Viena iš KPM karių tarnybų buvo konvojavimas, t. y. jie buvo skiriami lydèti suimtų, paprastai pavienių, karių. Tokią palydą sudarè vienas arba

${ }^{216}$ R. Čepas, Plečkaitininkai, p. 19.

${ }^{217}$ K. Škirpa, Pakeliui su Mykolu Šleževičiumi, Mykolas Sleževičius, p. 261-263.

${ }^{218}$ J. Demereckis, Savanorio ir kontržvalgybininko atsiminimai, p. 41-43.

${ }^{219} 1935$ m. spalio 31 d. Kauno miesto ir apskrities komendanto issakymas Nr. 307/2 komendantūrai, LCVA, f. 1471, ap. 1, b. 26, 1. 314.

${ }^{220} 1920 \mathrm{~m}$. vasario 4 d. Kauno karo komendanto ịsakymas Nr. 35/2 komendantūrai, ten pat, b. 219, 1. 87. 
du KPM kariai, dažniausiai grandiniai arba puskarininkiai ${ }^{221}$. Konvojuodami suimtuosius, kariai privalejo vadovautis Vidaus tarnybos statutu ${ }^{222}$. Iki Antrojo pasaulinio karo pradžios suimtųjų konvojavimas nebuvo dažna KPM kariams skiriama užduotis, taip, kaip minèta, buvo sudaroma pavienių nusikaltusiụjų palyda. 1939 m. rugsèjo 1 d., Vokietijai užpuolus Lenkiją, Lenkijos ir Lietuvos pasienyje telkèsi lenkų kariai, kurie, gelbẻdamiesi nuo persekiojančių vokiečių, rusų karių, Lietuvoje ieškojo prieglobsčio. Pasienyje kariai buvo nuginkluojami ir internuojami, vèliau siunčiami ị Birštone, Kulautuvoje, Palangoje, Ukmergèje, Rokiškyje, Alytuje ir kitur jiems įrengtas stovyklas ${ }^{223}$.

Pažymėtina, kad KPM viena iš funkcijų buvo tik karių (ne civilių pabėgèlių) konvojavimas. KPM kariai dažniausiai internuotus lenkus lydėdavo iš Kauno karo ligoninès ar Kauno komendantūros karo kalejjimo ị Ukmergès, Rokiškio, Palangos, Kulautuvos, Kalvarijos stovyklas ${ }^{224}$, palydovais buvo skiriama po kareivị vienam internuotajam, didesnei grupei (apie 30 internuotųjų) - penki KPM kariai (grandiniai arba puskarininkiai) ${ }^{225}$, eiliniams kariams tokios užduotys nebuvo duodamos.

\section{Nuobaudų sistema}

KPM karių tarnyba buvo reglamentuota kariuomenės Vidaus tarnybos statuto drausmès taisyklių. Deja, neišvengta jų pažeidimų. Tarnybos metu

${ }^{221} 1935$ m. sausio 20 d. Kauno miesto ir apskrities komendanto ísakymas Nr. 20/2 komendantūrai, ten pat, b. 26, 1. 20; 1937 m. spalio 7 d. Kauno miesto ir apskrities komendanto įsakymas Nr. 282/4 komendantūrai, ten pat, b. 42, 1. 285.

${ }^{222}$ İsakymas kariuomenei Nr. 66/1, 1937 m. lapkričio 19 d.

${ }^{223}$ S. Raštikis, Kovose dèl Lietuvos, Kario atsiminimai, Los Andželas, 1956, t. 1, p. 599, 601-602; Internuota keli tūkstančiai lenkų karių, Trimitas, 1939, Nr. 39, p. 945-946.

${ }^{224}$ Kulautuvoje ir Kalvarijoje buvo įrengtos stovyklos tik internuotiems lenkų karininkams: L. Mitkiewicz, Kauno atsiminimai (1938-1939), p. 289.

${ }^{225} 1939$ m. lapkričio 29 d. Karo policijos mokyklos karių kelionès liudijimai, LCVA, f. 1471, ap. 1, b. 93, 1. 452, 455; 1939 m. lapkričio 21 d. II internuotųjų stovyklos komendanto raštas dèl internuoto lenko pristatymo ị stovyklą, ten pat, 1. $491 ; 1940 \mathrm{~m}$. sausio $25 \mathrm{~d}$. Kauno miesto ir apskrities komendantūros Karo kalèjimo viršininko raportas Kauno miesto ir apskrities komendantui dèl karių paskyrimo internuotųjų lydejjimui, ten pat, b. 114, 1. 16; 1940 m. sausio-vasario ménesių Karo policijos mokyklos karių kelionès liudijimai, ten pat, 1. 2, 10, 22, 62 . 
padariusiems nusižengimą kariams buvo taikomos drausminès nuobaudos pagal minèto statuto drausmès taisyklių pažeidimo ${ }^{226}$ nuostatas. Drausminès nuobaudos galejjo būti taikomos tik už nedidelius nusižengimus tarnybai ar viešajai tvarkai, o už padarytus nusikaltimus kariai buvo traukiami baudžiamojon atsakomybèn. Paprastai kariams (eiliniams, grandiniams, puskarininkiams) buvo taikomos šios drausminès nuobaudos: laipsnio atèmimas (grandiniams ir puskarininkiams), skyrimas ị žemesnes pareigas, areštas (paprastas arba sunkusis), papeikimas, neišleidimas atostogų, skyrimas be eilès ị tarnybą (tik eiliniams ir grandiniams), draudimas išeiti iš kareivinių, stovejjimas su šautuvu ant peties (tik eiliniams ir grandiniams) ${ }^{227}$.

KPM karių drausminius nusižengimus galima apibendrinti panagrinèjus 1934-1936 m. mokyklos drausmès nuobaudų žurnalą ${ }^{228}$, kuriame užfiksuoti KPM eilinių ir grandinių nusižengimai ir jiems skirtos nuobaudos. Dažniausiai pasitaikantys karių nusižengimai buvo: neatidumas šaudymo pratybų metu - šaudymas ne ị savo taikinius, netikslus taktinių manevrų atlikimas; netikslus komandos vykdymas rikiuoteje - kojos nepakèlimas, neteisingas sukinių atlikimas; netinkama šautuvo priežiūra (neišvalymas); nemokejjimas viršininkui raportuoti; rečiau pasitaikantys nusižengimai pagarbos neatidavimas vyresniam laipsniu; netinkamas ịsakymo vykdymas; vẻlavimas ị rytinę mankštą arba grịžti iš miesto ị kareivines; savavališkas pasišalinimas iš kareivinių; nepranešimas apie gautą nuobaudą; melavimas ir atsikalbinejjimas; neatidumas pamokų metu; vengimas eiti i pamokas; triukšmavimas arba rūkymas kareivinèse; netinkamas uniformos dèvejimas; batų nevalymas; veido nepriežiūra (barzdos neskutimas). Už minètus nusižengimus dažniausiai skiriama nuobauda - vienos ar dviejų valandų stovejjimas su šautuvu (paprastas, rečiau - su visa ekipuote), areštas buvo taikomas už itin retai pasitaikančius nusižengimus: miegojimą sargybos vietoje (paprastasis ${ }^{229}$ keturiolikos parų areštas), kario įžeidi-

\footnotetext{
${ }^{226}$ Vyriausiojo štabo Spaudos ir švietimo skyrius, Vidaus tarnybos statutas, Kaunas, 1931, p. $1-28$.

${ }^{227}$ Ten pat, p. 4-7.

${ }^{228}$ 1934-1936 m. Karo policijos mokyklos drausmès pabaudų žurnalas, LCVA, f. 1471, ap. 1, b. 21, 1. 1-199.

${ }^{229}$ Paprastasis areštas - suimtieji laikomi atskirai šviesioje kameroje, kiekvieną dieną jiems duodama šilto maisto, miegama ant grindų, leidžiama turèti milinę, antklodę ir pagalvę, Vyriausiojo štabo Spaudos ir švietimo skyrius, Vidaus tarnybos statutas, Kaunas, 1931, p. 20.
} 
nëjimą (penkių parų sunkusis ${ }^{230}$ areštas), pakartotinị pasišalinimą iš kareivinių (penkių parų paprastasis areštas), už kelis nusižengimus vienu metu - nedrausmingą elgesí, atsisakymą nurodyti savo tapatybę, netinkamą uniformos dévejimą ir nesisveikinimą mieste - buvo skiriamas trijų parų paprastasis areštas ${ }^{231}$. Pažymètina, kad dèl daugiau negu trijų pakartotinių nusižengimų, tokių kaip pasišalinimas iš kareivinių, kariai buvo šalinami iš Karo policijos mokyklos kaip „nepataisomi ir demoralizuojantys kitus karius asmenys “232. Iš karo policininkų (puskarininkių) padarytų tarnybinių nusižengimų galima paminèti trijų patruliavusių Gaižiūnų poligone karo policininkų nusižengimą. Vienas karo policininkas leido išvykti kitiems dviem karo policininkams ị Kauną, nors neturejjo teisès to daryti. Visi trys kariai buvo nubausti paprastuoju penkių parų areštu ${ }^{233}$. Iš pateiktų duomenų matyti, kad Karo policijos mokyklos karių nusižengimai daugiausia buvo smulkūs ir padaryti dèl nepatyrimo, o ne dèl drausmès stokos, nepažeidžiantys bendrosios mokyklos drausmès. Rimtesnių nusižengimų pasitaikydavo retai, dažniausiai juos padarydavo eiliniai kariai, o nuolatiniai (pakartotiniai) taisyklių pažeidinejjimo atvejai netoleruojami - kariai buvo šalinami iš KPM tarnybos.

Apibendrinant karių tarnybas pažymètina, kad Karo policijos mokyklos kariai èjo įvairias tarnybines pareigas. Pirmiausia nuolat saugojo karinius ir strateginius objektus, budejo kovinès parengties, patruliavo Kauno mieste ir Gaižiūnų poligone, atlikdavo ikiteisminio tyrimo veiksmus, susijusius su karių tarnybiniais nusižengimais ir nusikaltimais, vykdẻ

\footnotetext{
${ }^{230}$ Sunkusis areštas - vykdomas taip pat kaip paprastasis, išskyrus tai, kad suimtieji šilto maisto gauna kas antrą dieną, jiems neleidžiama turèti antklodès ir pagalvès, ten pat.

${ }^{231} 1921$ m. rugpjūčio 30 d. Kauno ígulos viršininko įsakymas Nr. 52/8 Kauno igulai, LCVA, f. 1126, ap. 2, b. 2, 1. 47; 1934-1936 m. Karo policijos mokyklos drausmès pabaudu žurnalas, ten pat, f. 1471, ap. 1, b. 21, 1. 53ap; 1937 m. rugsejjo 1 d. Kauno miesto ir apskrities komendanto įsakymas Nr. 246/2 komendantūrai, ten pat, b. 42, 1. 249; 1935 m. gegužès 18 d. Kauno miesto ir apskrities komendanto įsakymas Nr. 138/2 komendantūrai, ten pat, b. 26, 1. 138.

${ }^{232} 1938 \mathrm{~m}$. balandžio 8 d. Karo policijos mokyklos viršininko raportas bataliono vadui dèl tarpininkavimo traukiant eil. Boleslovą Levinską baudžiamojon atsakomybèn, ten pat, b. 63, 1. 108.

${ }^{233} 1937$ m. spalio 11 d. Gaižiūnų poligono komendanto įsakymas Nr. 284/4 poligono komendantūrai, ten pat, 1. 446.
} 
apsaugos funkcijas delegacijų vizitų ir renginių metu, saugojo Valstybės Prezidentą, prireikus atlikdavo garbès sargybos vaidmeni, priešgaisrinès apsaugos funkcijas ir gaisrų likvidavimo darbus, kuriuose tekdavo dalyvauti ir kitiems mokyklos kariams. Specialiąsias tarnybines užduotis KPM kariai vykdè per sukilimus ir įrodė karo policijos tarnybos svarbą. Kitos KPM karių pareigos dažniausiai buvo ịvairūs tarnybiniai pavedimai ir konvojavimas. Tarnybos metu pasitaikydavo KPM karių tarnybą reglamentuojančių taisyklių pažeidimų, dažniausiai - smulkių. Buvo sudarytos sąlygos tarnybą atlikti tik drausmingiausiems karo policininkams. Pakartotinai nusižengusius karius vadovybè šalino iš mokyklos.

\section{Kitos karių veiklos kryptys (šventės, laisvalaikis)}

Iprastinę Karo policijos mokyklos karių tarnybą paįvairindavo dalyvavimas kasmetėse valstybinèse, religinèse ir kitokio pobūdžio šventèse ir minejjimuose, kurių metu buvo rengiami ne tik kariuomenès paradai, pamaldos bažnyčioje, bet ir paskaitos, pasilinksminimai kariams. Kasmet buvo organizuojamos šventès: vasario $16 \mathrm{~d}$. (Lietuvos valstybės atkūrimo diena), Velykų šventè, gegužès trečiasis sekmadienis (Kariuomenès ir visuomenès suartèjimo šventė) ${ }^{234}$, birželio $13 \mathrm{~d}$. (Respublikos Prezidento Antano Smetonos vardo diena) $)^{235}$, rugsẻjo $8 \mathrm{~d}$. (Tautos švente் ${ }^{236}$, lapkričio 2 d. (Vèlinès), lapkričio $23 \mathrm{~d}$. (Lietuvos kariuomenès šventė), gruodžio $24 \mathrm{~d}$. (šv. Kūčios) $)^{237}$. Visose minètose šventèse KPM kariai dalyvaudavo kasmet.

\footnotetext{
${ }^{234} 1935$ m. gegužès 26 d. pirmą kartą buvo pradèta švęsti Kariuomenès ir visuomenès suartėjimo šventè, siekiant užpildyti spragas, atsiradusias tarp kariuomenès ir visuomenès po 1926 m. gruodžio 17 d. ịvykių, padidinti pasitikejjimą kariais. Pagrindiniai šios šventès iniciatoriai ir organizatoriai buvo Vytauto Didžiojo universiteto studentų - atsargos karininkų - korporacijos „Ramove““ nariai: S. Raštikis, Kovose dèl Lietuvos, Kario atsiminimai, p. 380, 383.

${ }^{235} 1926$ m. gruodžio 19 d. pradèta kasmet minèti A. Smetonai tapus prezidentu.

${ }^{236}$ Nuo $1930 \mathrm{~m}$. rugsėjo $8 \mathrm{~d}$. pradèta švęsti Tautos šventę, siejant ją su $1430 \mathrm{~m}$. Vytauto Didžiojo planuota karūnavimo diena, Respublikos Prezidento kalba, pasakyta rugsèjo 8 d. per kariuomenès paradą, Karys, 1930, Nr. 37, p. 727-732.

${ }^{237}$ Issakymas kariuomenei Nr. 138/1, 1927 m. gruodžio 3 d.; ten pat, Nr. 83/1, 1935 m. lapkričio $8 \mathrm{~d}$.
} 
Lietuvos valstybès atkūrimo dieną mokyklos kariai pirmiausia privalèjo dalyvauti Kauno ịgulos bažnyčioje (dabar - Kauno Šv. Arkangelo Mykolo bažnyčia) rengiamose pamaldose, po jų - iškilmingame minejjime ${ }^{238}$ aikšteje prie Karo muziejaus. Vakare Kauno igulos karininkų ramovejje karininkams ir jų šeimų nariams buvo rengiamos paskaitos, susijusios su Lietuvos valstybingumo atgavimu, o atskirose kariuomenès dalyse - kareiviams. Pažymėtina, kad KPM kariai tą dieną ne tik dalyvaudavo iškilmėse, bet ir buvo skiriami tvarkai palaikyti Kauno Šv. apaštalų Petro ir Povilo arkikatedroje bazilikoje, Kauno igulos bažnyčioje ir minejjimo metu ${ }^{239}$.

Velykų šventès išvakarèse Kauno igulos bažnyčioje kariams buvo rengiamos pamaldos, jose dalyvaudavo laisvi nuo tarnybos karininkai, Karo policijos mokyklos, 1-ojo husarų Lietuvos didžiojo etmono kunigaikščio Jonušo Radvilos, 2-ojo pėstininkų Lietuvos didžiojo kunigaikščio Algirdo pulko, 5-ojo pėstininkų Lietuvos didžiojo kunigaikščio Kęstučio pulkų, aviacijos, karo technikos dalių ir 3-iojo artilerijos pulko kariai. Šių pamaldų metu tvarkai bažnyčioje palaikyti buvo skiriama karo policijos kuopa ir atvykusių dalių kariai ${ }^{240}$. Būtina paminèti ir tai, kad ị didžiąsias Velykų pamaldas buvo kviečiami tik jose norintys dalyvauti Karo policijos mokyklos ir 1-ojo husarų Lietuvos didžiojo etmono kunigaikščio Jonušo Radvilos pulko kariai, nes tai nebuvo privaloma ${ }^{241}$. Šv. Velykų dienos rytą kariams buvo rengiami tradiciniai velykiniai pusryčiai, dainuojamos karių dainos, juose dalyvaudavo ir Kauno karo komendantas, o vakare vykdavo šokių vakaras ${ }^{242}$.

\footnotetext{
${ }^{238}$ Minèjimo metu sveikinimo kalbas sakydavo Vyriausybės nariai, grodavo kariuomenès orkestrai, parodomąją programą atlikdavo garbės sargyba, kuriai $1934 \mathrm{~m}$. vadovavo Karo policijos mokyklos viršininkas kpt. A. Čepauskas. 1934 m. vasario 14 d. Kauno igulos viršininko įsakymas Nr. 3/1 Kauno igulai, $L C V A$, f. 1471, ap. 1, b. 12, 1. 3.

${ }^{239} 1922$ m. vasario 15 d. Kauno igulos viršininko įsakymas Nr. 2/1 Kauno igulai, ten pat, f. 1126, ap. 2, b. 2, 1. 50ap;

$1937 \mathrm{~m}$. vasario 14 d. Kauno miesto ir apskrities komendanto isakymas Nr. 45/2 komendantūrai, ten pat, f. 1471, ap. 1, b. 42, 1. 45.

${ }^{240} 1931 \mathrm{~m}$. balandžio 2 d. Kauno igulos viršininko įsakymas Nr. 11/1-2 Kauno igulai, ten pat, f. 1126, ap. 2, b. 33, 1. 6ap.

${ }^{241} 1933$ m. balandžio $12 \mathrm{~d}$. Kauno ịgulos viršininko įsakymas Nr. 4/1-2 Kauno ịgulai, ten pat, 1. 50ap.

${ }^{242}$ J. Ardzijauskas, Karo policijos mokykla, Karys, 1929, Nr. 15, p. 249-250.
} 
Kariuomenès ir visuomenès suartinimo šventès išvakarèse Karo muziejaus sodelyje buvo organizuojami vakariniai Karo policijos mokyklos ir 1-ojo husarų Lietuvos didžiojo etmono kunigaikščio Jonušo Radvilos pulko patikrinimai, jų metu buvo pagerbiami žuvę kariai, giedamas Lietuvos himnas, nuleidžiama vèliava. Šis patikrinimas Karo muziejaus sodelyje buvo transliuojamas per radiją. Po patikrinimų kariai su orkestru žygiuodavo ị savo dalis, iš lẻktuvų buvo mètomi pranešimai apie šventès programą, mieste kabinami plakatai su kareiviškais šūkiais. Šventės dieną KPM kareivinèse buvo iškeliamos vèliavos, visose Kauno bažnyčiose rengiamos pamaldos. KPM kariai ir kariuomenès įstaigų karininkai dalyvaudavo Kauno igulos bažnyčios pamaldose. Po pamaldų aikštejje prie Karo muziejaus buvo organizuojami minejjimai, vykdavo kariuomenès parodomosios programos, tam tikrose kareivinėse - „atvirų durų diena“, nors KPM kareivinèse tokios dienos nebuvo ${ }^{243}$. Tą dieną karo policininkai buvo skiriami tvarkai palaikyti ne tik Kauno igulos (taip pat per minejimą), bet ir kitose miesto bažnyčiose ${ }^{244}$. Verta prisiminti pirmąją, 1935 m. gegužès 26 d. vykusią, Kariuomenès ir visuomenès suartëjimo šventę, kadangi jos metu KPM kariai atliko parodomąjị būrio puolimą ${ }^{245}$. Pažymėtina, kad vèlesniais metais rengiamų Kariuomenès ir visuomenès suartejjimo švenčių metu KPM kariai nebeatlikdavo jokių parodomųjų programų, dalyvaudavo tik pamaldose ir minejjimuose, o karo policininkai - prižiūrèjo tvarką.

Prezidento A. Smetonos vardo dienai paminèti Kauno igulos bažnyčioje rengiamose pamaldose kasmet dalyvaudavo vienas, o nuo 1937 m. trys KPM būriai. Tą dieną prie mokyklos kareivinių buvo iškabinamos véliavos, vakare kareiviams skaitomos paskaitos apie Valstybės Prezidentą,

\footnotetext{
${ }^{243}$ Visuomenei buvo suteikta galimybè iš arti pamatyti karių gyvenimą, atlikti šaudymo pratimus, paragauti kareiviško valgio, kartu su kariais žygiuoti parade. Gegužès 26 dienos šventès programa, ten pat, 1935, Nr. 20, p. 456; Didžioji lietuvių šventè, ten pat, 1935, Nr. 21, p. 479.

${ }^{244} 1936$ m. gegužès 8 d. Kauno igulos viršininko įsakymas Nr. 6/1 Kauno igulai, LCVA, f. 1471, ap. 1, b. 29, 1. 6-7; 1937 m. gegužès 13 d. Kauno igulos viršininko ịsakymas Nr. 8/1 Kauno igulai, ten pat, b. 43, 1. 9-10; 1938 m. gegužès 7 d. Kauno igulos viršininko isakymas Nr. 9/1 Kauno igulai, ten pat, b. 62, 1. 10-11.

${ }^{245} 1935$ m. gegužès 23 d. Kauno miesto ir apskrities komendanto ísakymas Nr. 143/2 komendantūrai, ten pat, b. 26, 1. 143.
} 
jo veiklą ir nuopelnus ${ }^{246}$. Pamaldų metu tvarkai palaikyti nebuvo skiriama karo policininku, jie tik jose dalyvaudavo.

Nuo 1934 m. KPM kariai dalyvaudavo Tautos šventès dieną vykstančiose pamaldose ir paraduose, taip pat Respublikos Prezidento A. Smetonos 60-mečio minèjime. Tą dieną mokyklos kariams buvo skaitomos paskaitos apie jo nuopelnus, o vakare vyko pasilinksminimai. $1935 \mathrm{~m}$. tokios šventès metu buvo pradèti skirti karo policininkai tvarkai palaikyti aikštèse prie Karo muziejaus arba Petro Vileišio aikštèje, kur vykdavo kariuomenès paradai ${ }^{247}$.

Vèlinių dieną Karo policijos mokyklos kariai dalyvaudavo žuvusių karių pagerbimo minejjime Kauno katalikų kapinèse kaip tvarkos palaikytojai ${ }^{248}$, o Kariuomenès dienos proga - pamaldose, bet tvarkos palaikyti jų metu nebuvo skiriami. Karininkai dalyvaudavo minejjimuose ${ }^{249}$. Kariuomenės dešimties metų sukakties proga KPM kariai buvo atleisti nuo tarnybos. Laisva diena buvo skirta paskaitoms apie Lietuvos kariuomenę, jos kūrimą, Nepriklausomybès kovas, kariuomenès paskirtị ir panašiai, buvo patiekta geresnio maisto, vakare - surengti pasilinksminimai, o pamaldos vyko tik kitą dieną ${ }^{250}$. Kasmet gruodžio $24 \mathrm{~d}$. KPM kariams buvo rengiama tradicinė šv. Kūčių vakarienè, dalyvaujant Kauno karo komendantui, o 1939 m. joje dalyvavo ir kariuomenès vadas brg. gen. Stasys Raštikis. Po vakarienès kariai dalyvaudavo Bernelių mišiose ${ }^{251}$.

Karo policijos mokyklos kariai kasmet dalyvaudavo Kauno komendantūros metinėse šventėse. Jų metu kariams nebūdavo pamokų, visi

\footnotetext{
${ }^{246} 1932 \mathrm{~m}$. birželio $11 \mathrm{~d}$. Kauno ịgulos viršininko įsakymas Nr. 9/1 Kauno igulai, ten pat, b. 33, 1. 32; 1937 m. birželio 9 d. Kauno igulos viršininko įsakymas Nr. 10/1-2 Kauno igulai, ten pat, b. $43,1.12$

${ }^{247} 1934$ m. rugsejjo 3 d. Kauno igulos viršininko įsakymas Nr. 24/1 Kauno igulai, ten pat, b. 12, 1. 25-26; 1935 m. rugpjūčio 21 d. Kauno ịgulos viršininko įsakymas Nr. 36/1 Kauno igulai, ten pat, b. 29, 1. 30-30ap.

${ }^{248} 1928$ m. spalio 31 d. Kauno igulos viršininko įsakymas Nr. 25/1 Kauno igulai, ten pat, f. 1126, ap. 2, b. 17, 1. 20.

${ }^{249} 1931$ m. lapkričio 20 d. Kauno igulos viršininko įsakymas Nr. 35/1-2 Kauno igulai, ten pat, b. 33, 1. 21ap-22.

${ }^{250} 1928$ m. lapkričio 21 d. Kauno igulos viršininko įsakymas Nr. 26/1 Kauno igulai, ten pat, b. 17, 1. 22 .

${ }^{251} 1931$ m. gruodžio 22 d. Kauno ịgulos viršininko įsakymas Nr. 38/1 Kauno igulai, ten pat, b. 33, l. 24ap; Kariuomenès vadas Karo policijos mokykloje, Karys, 1939, Nr. 60, p. 1536.
} 
mokyklos kariai privalejo dalyvauti pamaldose Kauno igulos bažnyčioje ir parade, kuriam vadovaudavo Kauno karo komendantas arba KPM viršininkas. Šventė buvo rengiama Nepriklausomybės aikšteje arba prie KPM. Po parado buvo ruošiami pietūs KPM kareivinèse, o vakare - rodomi kino filmai mokyklos kariams ${ }^{252}$.

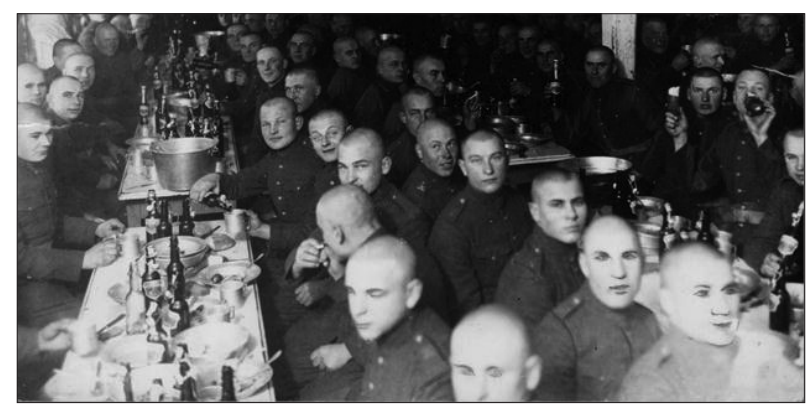

Iškilmingi bendri pietūs Karo policijos mokykloje per Kauno komendantūros metinę šventę. 1935 sausio $5 \mathrm{~d}$. (LCVA)

Šioje šventeje dalyvaudavo Kariuomenès štabo, Kauno igulos, Kauno komendantūros karininkai, Vyriausybès nariai ir KPM kariai. Kovo 15 d. (eil. Prano Eimučio ${ }^{253}$ žūties dieną) KPM kariai kasmet tylos minute pagerbdavo žuvusijji prie viešbučio „Metropolis“, vykdavo ị karių kapines prie kario kapo, vakare kariams buvo rengiamos paskaitos apie savanorio žūtị ${ }^{254}$. 15-ųjų eil. P. Eimučio mirties metinių proga buvo surengtas iškil-

${ }^{252} 1930 \mathrm{~m}$. sausio 5 d. Kauno miesto ir apskrities komendanto įsakymas Nr. 5/2 komendantūrai, LCVA, f. 1126, ap. 4, b. 37, 1. 8ap; 1934 m. sausio 4 d. Kauno miesto ir apskrities komendanto įsakymas Nr. 5/1 komendantūrai, ten pat, f. 1471, ap. 1, b. 14, 1. 4. ${ }^{253} 1919$ m. kovo 15 d. j̇ Kauną buvo atvykusi JAV santarvès misija ir apsistojo viešbutyje „Metropolis“. Prie viešbučio budejo garbès sargyba, sudaryta iš Kauno komendantūros mokomosios komandos kareivių. Kovo 18 d. vokiečių kariai bande ịsiveržti ị viešbutị, jiems kelią pastojo sargybinis eil. Pranas Eimutis. Vokietis karys paleido ị sargybinị du šūvius ir ji mirtinai sužeidè. Kovo $21 \mathrm{~d}$. buvo surengtos iškilmingos kareivio P. Eimučio laidotuvès. Vèliau KPM kareivinèse šio kareivio atminimui buvo pakabinta paminklinė lenta, o 1939 m. buvo įtrauktas ị mokyklos 1-osios kuopos sąrašus ir šaukiamas per vakarinius patikrinimus. Vyr. ltn. Gužas, Atsiminimai iš Kauno karo komendantūros darbų 1919 m. sausio-kovo mèn., Karo archyvas, 1925, t. 1, p. 200-203; 1939 m. kovo 9 d. Karo policijos mokyklos viršininko raportas Kauno miesto ir apskrities komendantui dèl žuvusių karių pagerbimo, LCVA, f. 1471, ap. 1, b. 93, 1. 103.

${ }^{254} 1937 \mathrm{~m}$. kovo 17 d. Kauno miesto ir apskrities komendanto issakymas Nr. 76/2 komendantūrai, ten pat, b. 42, 1. 76. 
mingas minejjimas ir pamaldos, jose dalyvavo beveik visų Kauno igulos dalių kariai. KPM kariai kartu su Kauno miesto ir apskrities komendantūros ir 1-ojo husarų Lietuvos didžiojo etmono kunigaikščio Jonušo Radvilos pulko kariais sudarè garbės sargybos kuopą, po pamaldų kapinèse buvo šventinamas žuvusiojo paminklas, vakare vyko iškilmingas minejimas ir paminklinès lentos atidengimo prie minèto viešbučio ceremoni$\mathrm{ja}^{255}$. Pažymėtina, kad šiuose Kauno karo komendanto organizuojamuose minejimuose karo policininkai nebuvo skiriami tvarkos palaikyti, nes buvo vieni iš pagrindinių dalyvių.

Be minètų kasmečių švenčių ir minejjimų, KPM kariai dalyvaudavo ir ịvairiuose kituose renginiuose. Iš jų galima keletą paminèti. $1921 \mathrm{~m}$. ir 1922 m. gegužès 15 d. Petro Vileišio aikšteje vyko Kauno igulos dalių paradas Steigiamojo Seimo metinėms paminèti ${ }^{256} .1921 \mathrm{~m}$. spalio 16 d. Karo milicijos mokyklos kariai dalyvavo paminklo „Žuvusiems už Lietuvos laisvę" atidengimo iškilmèse ${ }^{257}, 1922$ m. rugsèjo 29 d. - prie Karo muziejaus minejjime, skirtame Vilniaus 600 metų jubiliejui ${ }^{258}$, rugpjūčio 2 d. - Petro Vileišio aikšteje kariuomenès parade Lietuvos Konstitucijos prièmimo dienai paminèti ${ }^{259} .1929$ m. gegužès 27 d. vienas KPM būrys dalyvavo Kauno igulos bažnyčioje gedulingose pamaldose, skirtose žuvusiam kpt. Pranui Gudynui ${ }^{260}$, o 1932 m. rugsejjo 25 d. - Lietuvos didžiojo kunigaikščio Vytauto 550 metų mirties metinėms

\footnotetext{
${ }^{255} 1934$ m. kovo 15 d. Kauno ịgulos viršininko įsakymas Nr. 5/1 Kauno igulai, ten pat, b. 12, 1. 5 . ${ }^{256} 1921$ m. gegužès 14 d. Kauno igulos viršininko įsakymas Nr. 22/1 Kauno igulai, ten pat, f. 1126, ap. 2, b. 2, 1. 18ap; 1922 m. gegužès 13 d. Kauno igulos viršininko įsakymas Nr. 8/1 Kauno igulai, ten pat, 1. 63.

${ }^{257} 1921 \mathrm{~m}$. spalio 14 d. Kauno ịgulos viršininko ịsakymas Nr. 53/1 Kauno igulai, ten pat, 1. 48. ${ }^{258} 1922$ m. rugsèjo 29 d. Generalinio kariuomenès štabo viršininko raštas Kauno miesto ir apskrities komendantūrai dèl kariuomenès dalių dalyvavimo minejjime, ten pat, b. 222, 1. 80. ${ }^{259} 1922$ m. rugpjūčio $1 \mathrm{~d}$. Generalinio kariuomenès štabo viršininko raštas Kauno miesto ir apskrities komendantūrai dèl kariuomenès parado, ten pat, 1. 92.

${ }^{260} 1929$ m. gegužès 6 d. vyr. ltn. P. Gudynas, ministro pirmininko Augustino Voldemaro adjutantas, užstojo pastarąji per ginkluotą pasikèsinimą ir buvo mirtinai sužeistas. Po mirties buvo apdovanotas Vyčio Kryžiaus ordinu, jam buvo suteiktas kapitono laipsnis, 1929 m. gegužès 24 d. Kauno igulos viršininko ịsakymas Nr. 288/1 Kauno igulos dalių vadams, ten pat, b. 22, 1. 11; Respublikos Prezidento aktai, Karys, 1929, Nr. 18, p. 291; Pranas Gudynas - kapitonas, ten pat, 1929, Nr. 19-20, p. 343.
} 
paminèti ${ }^{261}, 1934 \mathrm{~m}$. vasario $11 \mathrm{~d}$. - pamaldose ir karių kapinèse vykusiame minejjime pirmosioms Nepriklausomybès kovų aukoms pagerbti ${ }^{262}$, rugpjūčio 12 d. - iškilmingose pamaldose Kauno arkikatedroje bazilikoje Jūros dienos proga (taip pat KPM kariams buvo rengiamos paskaitos apie Klaipėdos krašto svarbą Lietuvai) ${ }^{263}$, rugpjūčio 26 d. pamaldose, skirtose $1920 \mathrm{~m}$. Lietuvos kariuomenès įžengimui į Vilnių paminèti, po kurių mokyklos kariams buvo skaitomos paskaitos apie ši ịvykį ${ }^{264}, 1939 \mathrm{~m}$. vasario 15 d. - gedulingose pamaldose už Popiežių Pijų XI ${ }^{265}$. Be to, kiekvieną sekmadienị laisvi nuo tarnybos Karo policijos mokyklos kariai privalejo dalyvauti sekmadieninèse pamaldose Kauno ígulos bažnyčioje ${ }^{266}$. Iš pateiktos informacijos matyti, kad KPM kariai dalyvaudavo ne tik kasmetèse valstybinèse ir religinėse šventėse, bet ir kitokio pobūdžio renginiuose. Per vienus metus kariams tekdavo dalyvauti mažiausiai dešimtyje ịvairių švenčių ir renginių.

Karo policijos mokyklos kariai turejo teisę i poilsị ir laisvalaikị. Darbo dienomis laisvu laiku jie pirmiausiai ruošdavosi kitos dienos pamokoms, galèjo skaityti ịvairias knygas mokykloje įrengtoje skaitykloje, sportuodavo, vakarinių pasivaikščiojimų metu grodavo skudučiais KPM skudučių orkestre. Nežinoma, kokias knygas mokyklos kariai skaitė. Galima tik pasakyti, kad buvo populiari karinè periodinè spauda, ypač Lietuvos kariuomenès savaitinis laikraštis „Karys“, populiariausias tarp mokyklos liktinių puskarininkių, kurie prenumeruodavo ji kiekvienais metais ${ }^{267}$.

${ }^{261} 1932$ m. rugsėjo 24 d. Kauno ịgulos viršininko ịsakymas Nr. 19/1 Kauno igulai, LCVA, f. 1126 , ap. 2, b. $33,1.39$.

${ }^{262} 1919$ m. vasario 9 d. kovose su bolševikais prie Kẻdainių žuvusị kareivị Povilą Lukšị ir vasario 13 d. Alytuje žuvusị 1-ojo pėstininkų Lietuvos didžiojo kunigaikščio Gedimino pulko vadą krn. Antaną Juozapavičių, 1934 m. vasario 9 d. Kauno igulos viršininko isakymas Nr. 2/1 Kauno igulai, ten pat, f. 1471, ap. 1, b. 12, 1. 2.

${ }^{263} 1934$ m. rugpjūčio 7 d. Kauno igulos viršininko ịsakymas Nr. 21/1 Kauno igulai, ten pat, 1. 20.

${ }^{264} 1934$ m. rugpjūčio 24 d. Kauno ịgulos viršininko ịsakymas Nr. 23/1 Kauno igulai, ten pat, 1. 22.

2651939 m. vasario 14 d. Kauno igulos viršininko telefonograma Nr. 33 Karo policijos mokyklos viršininkui dèl gedulingų pamaldų, ten pat, b. 93, 1. 59.

${ }^{266} 1921 \mathrm{~m}$. liepos 26 d. Kauno igulos viršininko įsakymas Nr. 39/3 Kauno igulai, ten pat, f. 1126 , ap. 2, b. 2, 1. 27.

${ }^{267}$ Z. Gerulaitis, Karo policijos mokykla, Karys, 1938, Nr. 1, p. 29. 
Tarp karių buvo populiarios įvairios sporto rūšys: futbolas, stalo tenisas, šachmatai. KPM kariai dalyvaudavo draugiškose futbolo rungtynėse su kitomis kariuomenès dalinių arba civilių komandomis ${ }^{268}$. Stalo tenisas buvo pradètas propaguoti tik 1937 m., kai mokykla įsigijo šio sporto inventoriaus ${ }^{269}$. Tačiau mokykla stalo tenisininkų komandą suburdavo ne kasmet. Pvz., 1939 m. pabaigoje KPM stalo tenisininkų nebuvo ${ }^{270}$. Karių šachmatų turnyrai nebuvo rengiami, žaidimas buvo propaguojamas tik tarp mokyklos karių. 1934 m. KPM rajone buvo įrengta čiuožykla, ị ją buvo įleidžiami tik mokyklos ir komendantūros kariai, jų šeimų nariai ir draugai ${ }^{271}$.

Daugiau laisvalaikio KPM kariai turejo savaitgaliais. Tai mokyklos vadovybè stengèsi išnaudoti prasmingai. Kariams buvo rengiamos ekskursijos ị ivvairias Kauno miesto ir jo apylinkių vietas - Pažaislio vienuolyną, Tado Ivanausko zoologijos muziejų, M. K. Čiurlionio dailès muziejų, Kauno pilį, kitas Kauno igulos dalis (Šarvuočių rinktinę, Aviacijos dalị), kur jie supažindinami su kitų dalių ginklų rūšimis ${ }^{272}$, ̣̇ kino ir dramos teatrus, kur buvo rodomi filmai, spektakliai ${ }^{273}$. Neatskiriama karių veikla savaitgaliais buvo ir kareivinių tvarkymas, švaros jose palaikymas.

1926 m. Lietuvoje ịrengus radijo stotị ir pradejjus transliacijas, kariams buvo organizuojamos radijo laidos, o nuo XX a. 4-ojo dešimtmečio pradžios - reguliariai transliuojami kariuomenès pusvalandžiai ${ }^{274}$. Šių pusvalandžių metu buvo transliuojami ịvairūs karių dialoginiai vaidinimai, muzikos programos, deklamuojami eilèraščiai, literatūriniai pasakojimai,

${ }^{268}$ A. Rakauskas, Sporto kronika, ten pat, 1929, Nr. 28, p. 477; 1935 m. birželio 15 d. Gaižiūnų poligono komendanto raštas Karo policijos mokyklos viršininkui dèl futbolo rungtynių, LCVA, f. 1471, ap. 1, b. 23, 1. 170.

${ }^{269}$ Z. Gerulaitis, Karo policijos mokykla, Karys, 1938, Nr. 1, p. 29.

${ }^{270} 1939$ m. lapkričio 2 d. Aviacijos puskarininkių ramovès valdybos pirmininko raštas Karo policijos mokyklos sporto vadovui dèl stalo teniso rungtynių, LCVA, f. 1471, ap. 1, b. $93,1.461$.

${ }^{271}$ Kariai mėgsta mokslą ir pramogas, Karys, 1934, Nr. 4, p. 74.

${ }^{272}$ Ivairina kareivių gyvenimą, ten pat, 1934, Nr. 3, p. 54; Dažnai rengia ekskursijas, ten pat, 1934, Nr. 12, p. 235.

${ }^{273}$ Ūkio paskaitos kariams, ten pat, 1934, Nr. 9, p. 176; 1936 m. lapkričio 18 d. Kauno igulos viršininko raštas Karo policijos mokyklos viršininkui dèl kariams rengiamu spektaklių, LCVA, f. 1471, ap. 1, b. 31, 1. 315.

${ }^{274}$ A. Ažubalis, R. Kazlauskaitè-Markelienè, A. Petrauskaitè, B. Puzinavičius, F. Žigaras, Karo pedagogika Lietuvoje (1918-1940), Vilnius, 2007, p. 314, 344. 


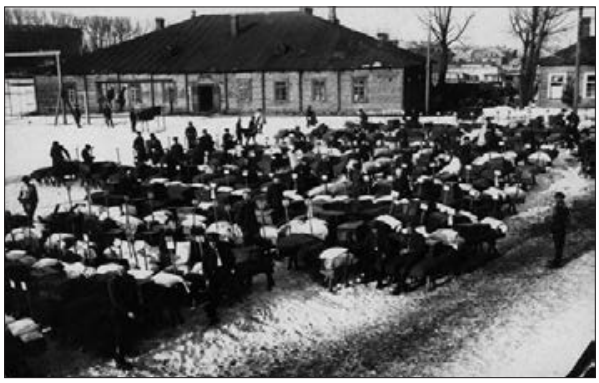

Karo policijos mokyklos kariai

lauke tvarko lovas, čiužinius, patalynę (LCVA)

pranešimai ir pan. ${ }^{275} \mathrm{KPM}$ kariai ne tik klausydavosi šių programų, bet ir patys jose dalyvaudavo, atlikdavo muzikos kūrinius, specialiai parengtus vaidinimus ir pan. ${ }^{276}$ Mokykloje rengiamų vakarèlių metu jie galejjo pademonstruoti savo kultūrinès saviveiklos rezultatus: KPM mėgèjų artistų būrelis kariams rengdavo parodomuosius vaidinimus, šokdavo baletą, styginių instrumentų orkestras atlikdavo muzikos kūrinius, kareivių choras - kareiviškas dainas, pavieniai kariai deklamuodavo savo kūrybos eiles $^{277}$. KPM skudučių orkestras kartais pasirodydavo šiuose vakarèliuose, bet dažniausiai grodavo per vakarinius kareivių pasivaikščiojimus ${ }^{278}$. Kariai saviveiklininkai pasirodymus kartais rengdavo ir Kauno komendantūros metinių švenčių proga, per pietus ${ }^{279}$.

Karo policijos kariai buvo įsitraukę ir labdaringą veiklą. 1934 m. dalyvavo Žmogaus globos draugijos organizuotoje aukų rinkimo akcijoje, kurios tikslas buvo padèti vargingai gyvenantiems kauniečiams. KPM ir kitų Kauno igulos dalių (1-ojo husarų Lietuvos didžiojo etmono kunigaikščio Jonušo Radvilos, 2-ojo péstininkų Lietuvos didžiojo kunigaikščio Algirdo, 5-ojo pėstininkų Lietuvos didžiojo kunigaikščio Kęstučio, 3-iojo arti-

2751940 m. vasario 3 d. Kariuomenès štabo Spaudos ir švietimo skyriaus viršininko nurodymai dèl kariuomenès pusvalandžių organizavimo, LCVA, f. 1471, ap. 1, b. 92, 1. 29. ${ }^{276}$ Z. Gerulaitis, Karo policijos mokykla, Karys, 1938, Nr. 1, p. 29; Karo policijos mokykla Valstybès radiofone, ten pat, 1939, Nr. 6, p. 193.

${ }^{277}$ Laukys, Žaliojo kalno igula, ten pat, 1927, Nr. 44, p. 404; Kariai mègsta darbą ir pramogas, ten pat, 1934, Nr. 7, p. 136.

${ }^{278}$ A. St-čius, Susižavi skudučių muzika, ten pat, 1934, Nr. 34, p. 690.

279 Z. Gerulaitis, Kauno komendantūros šventè, ten pat, 1938, Nr. 2, p. 67; Z. Gerulaitis, Paminèta Kauno komendantūros 20 metų sukaktis, ten pat, 1939, Nr. 2, p. 63. 
lerijos ir Atskirojo artilerijos pulkų, Aviacijos, Šarvuočių rinktinès, Ryšių ir Pionierių batalionų) kariai buvo atleisti nuo tarnybos tris dienas ir per jas rinko aukas ${ }^{280} .1938 \mathrm{~m}$. KPM kariai, išeidami ị atsargą, savanoriškai aukojo Ginklų fondui paskutinio ménesio atlyginimąa ${ }^{281}$. Be to, beveik visi KPM liktiniai puskarininkiai buvo Lietuvos aeroklubo ir Draugijos užsienio lietuviams remti nariai rèmėjai ${ }^{282}$.

Apibendrinant pasakytina, kad dalyvavimas šventèse Karo policijos mokyklos kariams buvo visokeriopai naudingas, kadangi jų metu buvo ugdomi tautiškumo, pilietiškumo, religingumo jausmai, visuomeniškumas. Karių laisvalaikis buvo organizuojamas taip, kad jie galètų tobulèti ne tik fiziškai, bet ir dvasiškai. Buvo stengiamasi juos visapusiškai ugdyti. Be to, Karo policijos mokyklos kariai buvo skatinami dalyvauti saviveikloje, visuomeninejje veikloje, įtraukiant juos ị visuomeninių organizacijų rengiamas akcijas.

\section{KARO POLICIJOS TARNYBOS LIKVIDAVIMAS}

1940 m. birželio 15 d., Lietuvos Vyriausybei prièmus Sovietų Sąjungos ultimatumą, baigèsi nepriklausomos Lietuvos Respublikos egzistavimas. Tuo metu valstybès viduje buvo pradėtos reformos, tarp jų - Lietuvos kariuomenès likvidavimas, kurị buvo numatyta vykdyti keliomis pakopomis. Iš pradžių stengtasi neutralizuoti kariuomenę, po to - performuoti i RA 29-ąji šaulių teritorinị korpusą (toliau - ŠTK). Pirmoji kariuomenès neutralizavimo plano dalis buvo susijusi su nepatikimų karininkų išleidimu ị atsargą, o likusių tarnyboje - perkèlimu ị kitas pareigas, siekiant užkirsti kelią ginkluotam pasipriešinimui. Tokie masiniai karininkų išleidimai į atsargą prasidejo birželio $25 \mathrm{~d} .{ }^{283}$ Vienas pirmųjų karininkų, išleistų $\mathfrak{i}$ atsargą, buvo Karo policijos mokyklos viršininkas mjr. E. Berentas, kuris

\footnotetext{
${ }^{280}$ Nedarbo naštos lengvinimo fronte, ten pat, 1934, Nr. 4, p. 75.

${ }^{281}$ Z. Gerulaitis, Karo policijos mokykla, ten pat, 1938, Nr. 17, p. 488.

${ }^{282}$ Kariai rūpinasi savo kraštu, ten pat, 1934, Nr. 14, p. 276.

${ }^{283}$ S. Knezys, Lietuvos kariuomenès likvidavimas 1940-1941 metais, Pirmoji sovietine okupacija. Okupacija ir aneksija. The First Soviet Occupation. Occupation and Annexation, Vilnius, 2006, t. I, p. 164, 171.
} 
ị atsargą buvo išleistas liepos $2 \mathrm{~d} \cdot{ }^{284}$ Pažymètina, kad ši kariuomenès neutralizavimo plano dalis Karo policijos mokyklos funkcionavimui didelès ìtakos neturẻjo, kadangi visi likę KPM karininkai buvo palikti eiti pareigų, išskyrus kpt. J. Sabaliauską, kuris rugpjūčio $21 \mathrm{~d}$. buvo perkeltas ị Karo ligoninę ${ }^{285}$. Daug labiau mokyklos veiklą paveikè antroji kariuomenés neutralizavimo plano dalis - daliniuose ịvesta politinè kontrolè. Liepos 4 d. kariuomenejje buvo pradètas formuoti politinių vadovų institutas. I ji atrinkti puskarininkiai ir eiliniai kareiviai turejjo kontroliuoti vadų veiklą, skleisti komunistines idejas ir užkirsti kelią bet kokiam ginkluotam pasipriešinimui ${ }^{286}$. KPM politinius vadovus kiekvienai kuopai skirdavo Kauno karinis viršininkas ${ }^{287} .1940 \mathrm{~m}$. vasarą KPM politinių vadovų pareigas ėjo: 1-osios prieššarvinès kuopos - grand. Antanas Lydeikis, 2-osios - eil. Pranas Janavičius, apsaugos kuopos - eil. Vladas Malkevičius ${ }^{288}$, vèliau - Povilas Cijūnèlis ${ }^{289}$. Rugsèjo 25 d. šie politiniai vadovai buvo atleisti iš pareigu kaip nepakankamai politiškai pasirengę. Vienintelis eil. P. Janavičius buvo paliktas eiti politinio vadovo pareigų, jis rugsejo $28 \mathrm{~d}$. buvo paskirtas viso Apsaugos bataliono politiniu vadovu ${ }^{290}$. Politiniai vadovai Karo policijos mokykloje turèjo plačius igaliojimus, jų žinioje buvo visa mokyklos veikla. Be politinių vadovų žinios KPM viršininkas negalëjo duoti nė vieno isakymo ar raporto, viskas buvo tikrinama. Svarbiausia tai, kad politiniai

\footnotetext{
${ }^{284}$ Lietuvos kariuomenès karininkai 1918-1953, Vilnius, 2002, t. II, p. 167.

${ }^{285}$ Ten pat, 2007, t. VII, p. 13.

${ }^{286}$ S. Knezys, Lietuvos kariuomenès likvidavimas 1940-1941 metais, Pirmoji sovietine okupacija. Okupacija ir aneksija. The First Soviet Occupation. Occupation and Annexation, p. 165-166.
}

${ }^{287} 1940$ m. birželio 28 d. buvo pakeistas Kauno miesto ir apskrities komendantūros pavadinimas - ji buvo pavadinta Kauno karine istaiga, Kauno komendantas - Kauno kariniu viršininku. 1940 m. liepos 5 d. Kauno karinio viršininko įsakymas Nr. 189/2 Kauno karinei įstaigai, LCVA, f. 1126, ap. 4, b. 46, 1. 171.

${ }^{288} 1940 \mathrm{~m}$. liepos $9 \mathrm{~d}$. Karo policijos mokyklos instrukcija ginklų sandèlio sargybiniui, ten pat, f. 1471 , ap. 1, b. 6, 1. 46.

${ }^{289}$ Tyrimo autorei P. Cijūnèlio karinis laipsnis nèra žinomas. Tikètina, kad minètas politinis vadovas buvo eilinis arba grandinis, nes kiti mokyklos politiniai vadovai turejo būtent šiuos karinius laipsnius.

${ }^{290} 1940$ m. rugsèjo 25 d. Kauno karinio viršininko įsakymas Nr. 271/3 Kauno karinei ìstaigai, $L C V A$, f. 1126, ap. 4, b. 46, 1. 239; 1940 m. rugsejjo 28 d. Kauno karinio viršininko issakymas Nr. 278/2 Kauno karinei įstaigai, ten pat, b. 47, 1. 4. 
vadovai visiškai kontroliavo ginklų išdavimą. Be jų žinios niekas negalejjo patekti ị KPM ginklų sandèlį, jie privalèjo dalyvauti sandèlị atidarant ir uždarant, ginklai galejo būti išduodami tik su politinių vadovų leidimu ${ }^{291}$. Tokia jų veikla varžè savarankišką KPM darbą.

Rugsèjo 2 d. buvo pradètas formuoti RA 29-asis ŠTK. Jị sudarè dvi šaulių divizijos (179-oji ir 184-oji ${ }^{292}$. Rugsèjo mèn. prasidejo ir KPM išformavimas. Mokyklai likviduoti per šešias paras buvo skirti 3 sunkvežimiai ir 15 karių. Jos turtas buvo gabenamas ị kariuomenès sandèlius ir kitas vietas. Likvidavimas vyko léčiau, nei numatyta, nes turtui išvežti iš Karo technikos valdybos prašytų transporto priemonių nebuvo gauta taip greitai, kaip tikètasi ${ }^{293}$. Nuo rugsèjo $25 \mathrm{~d}$. pasikeitè KPM tarnybos pobūdis, jai buvo paliktos tik sargybų tarnybos. KPM buvo pervadinta - tapo Apsaugos batalionu, o KPM viršininkas - šio bataliono viršininku. Batalione liko trys kuopos, tačiau kitaip pavadintos: 1-oji prieššarvine kuopa - 1-ąja kuopa, 2-oji prieššarvinè - 2-ąja kuopa, Apsaugos kuopa - 3-iąja kuopa. Pažymètina, kad kariams vietoje skirto padidinto maisto davinio buvo paskirtas paprastas maisto davinys ${ }^{294}$. Pasikeitus Karo policijos mokyklos pobūdžiui, buvo padidintas karių skaičius nuo 196 iki $265^{295}$. Nuo spalio 7 d. Apsaugos bataliono kariai buvo perkeliami į RA 29-ojo ŠTK dalis: ị 184-osios šaulių divizijos lengvosios artilerijos pulką ir divizijos prieštankinị batalioną buvo perkelta po šešis karius, o i̇ divizijos 297-ąji šaulių pulką - 93 kariai ${ }^{296}$. Spalio 10 d. ị šią diviziją buvo perkelti dar 127 kariai (ị 297-ajji šaulių

${ }^{291} 1940$ m. liepos 19 d. Karo policijos mokyklos instrukcija ginklų sandèlio sargybiniui, ten pat, f. 1471, ap. 1, b. 6, 1. 46.

${ }^{292}$ S. Knezys, Lietuvos kariuomenès likvidavimas 1940-1941 metais, Pirmoji sovietine okupacija. Okupacija ir aneksija. The First Soviet Occupation. Occupation and Annexation, p. $172-173$.

${ }^{293} 1940$ m. rugsèjo 10 d. Karo policijos mokyklos viršininko raportas Kauno kariniam viršininkui dèl mokyklos išformavimo, LCVA, f. 1471, ap. 1, b. 114, 1. 337; $1940 \mathrm{~m}$. rugsejjo 21 d. Kauno karinio viršininko telefonograma Nr. 273 Karo policijos mokyklos viršininkui dèl transporto priemonių, skirtų mokyklos likvidacijai, ten pat, 1. 357.

${ }^{294} 1940$ m. rugsèjo 23 d. Kauno karinio viršininko įsakymas Nr. 269/2 Kauno karinei istaigai, ten pat, f. 1126, ap. 4, b. 47, l. 11.

${ }^{295} 1940$ rugsèjo mèn. Karo policijos mokyklos paros sudèties žinios, ten pat, ap. 2, b. 290, 1. $299,309,310$.

${ }^{296} 1940$ m. spalio 7 d. Kauno karinio viršininko įsakymas Nr. 280/5 Kauno karinei įstaigai, ten pat, ap. 4, b. 46, 1. 246-246ap. 
pulką - 4, ì 294-ąji - 123) ${ }^{297}$. Spalio 13 d. batalione buvo likę tik 23 kariai: 5 karininkai, 2 viršilos, 7 puskarininkiai, 2 jaunesnieji puskarininkiai, 2 grandiniai ir 10 eilinių 298 . Galima sakyti, per ménesi, t. y. nuo rugsèjo $1 \mathrm{~d}$. iki spalio 10 d., karo policijos karių sumažejo 174 - nuo 197 iki 23.

Tenka konstatuoti, kad 1940 m. lapkričio 11 d. buvo likviduotas Lietuvos liaudies kariuomenès apsaugos batalionas, bataliono vadas kpt. I. Morkūnas perkeltas ị 179-osios šaulių divizijos 234-ajj ̨̌aulių pulką ir paskirtas šaulių kuopos vadu ${ }^{299}$. Ši likviduota tarnyba buvo atkurta tik po 58 metų - 1998-aisiais ${ }^{300}$.

Apibendrinant Karo policijos mokyklos likvidavimo eigą galima pasakyti, kad viskas buvo daroma planingai, taikant bendrus Lietuvos kariuomenès likvidavimo kriterijus. Pirmiausia KPM paveikė aukštų karininkų, kurie buvo išleisti $\mathfrak{i}$ atsargą arba rotuoti, nušalinimas, vẻliau - politinių vadovų kontrolès ịvedimas. Toliau vyko techniniai likvidavimo darbai: buvo išgabentas turtas, kariai perkelti i̇ 29-ojo ŠTK divizijas.

\section{IŠVADOS}

1. 1919 m. kovo 15 d. buvo pradèti pirmieji Lietuvos Respublikos kariuomenès karo policijos organizavimo darbai. Prie Kauno miesto komendantūros buvo pradèta formuoti Karo (lauko) milicijos kuopa, turejusi būti pagalbine Kauno milicijos jèga. Liepos $18 \mathrm{~d}$. kuopa buvo reorganizuota ir performuota ị Apskrities kuopą. Gruodžio $1 \mathrm{~d}$. buvo pradèta kurti Karo (lauko) milicijos komanda. Šios komandos pagrindu 1920 m. sausio $1 \mathrm{~d}$. buvo îsteigta Karo (lauko) milicijos mokykla. Ji pradejo rengti profesionalius karo policininkus. $1924 \mathrm{~m}$. spalio $1 \mathrm{~d}$. mokykla buvo pervardyta į Karo policijos mokyklą. 1919-1920 m. Karo (lauko) milicijos veikla buvo orientuota ị pagalbą viešajai milicijai malšinant ginkluotą pa-

\footnotetext{
${ }^{297} 1940$ m. spalio 10 d. Kauno karinio viršininko įsakymas Nr. 281/8 Kauno karinei istaigai, ten pat, 1. 247.

${ }^{298} 1940$ spalio mèn. Apsaugos bataliono paros sudèties žinios, ten pat, ap. 2, b. 290, 1. 323. ${ }^{299}$ Lietuvos kariuomenes karininkai 1918-1953, Vilnius, 2005, t. V, p. 278-279.

${ }^{300}$ Karo policijos informacija, Lietuvos kariuomenès Karo policija švenčia 90 metų jubiliejų, Krašto apsauga, 2009, Nr. 5, p. 10-11.
} 
sipriešinimą, atliekant kratas, areštus, ir ị Kauno komendantūros administracinius reikalus, karinių ir strateginių objektų apsaugą.

2. KPM buvo specifinè kariuomenès dalis. Jai buvo suteiktas atskirosios péstininkų kuopos statusas, o vadovybè užtikrino tinkamą karių mokymų ir tarnybų organizavimą. Vèlesnè mokyklos struktūros kaita siejama su karių skaičiaus didejjimu ir išplètotomis funkcijomis. Tinkamam mokyklos funkcionavimui užtikrinti buvo komplektuojamas personalas iš kompetentingų karių ir civilių. Pagrindinès pareigos buvo skiriamos karininkams. Mokyklos vidaus tvarka, kasdienis karių gyvenimas buvo reglamentuotas išskirtine dienotvarke, vidaus tvarką palaikė tinkamai organizuotos paros tarnybos ir budetojai. Pavojaus atveju mokyklos kariams buvo skirtos svarbiausių valstybinès reikšmès objektų apsaugos ir gynybos funkcijos.

3. Karo policijos mokyklos mokymo sistema buvo orientuota ị ịvairiapusị karo policininkų rengimą. Kariams buvo suteikiama ne tik bendrojo lavinimo ir karybos teorinių žinių, bet ir atitinkamų praktinių igūdžių. Karo policininkai individualios uniformos neturejo, buvo dèvima pėstininkų uniforma, tik su karo policijos tarnybos ženklu, tačiau ginkluotė buvo skirta specialiai karo policijos tarnybai atlikti. KPM likvidavimas, užtrukęs iki 1940 m. lapkričio 11 d., buvo vykdomas planingai, taikant bendrus Lietuvos kariuomenès likvidavimo kriterijus.

4. Karo policijos mokyklos kariai ejjo įvairias tarnybines pareigas: saugojo karinius ir strateginius objektus, budejo kovinès parengties, patruliavo, vykde ikiteisminio tyrimo veiksmus, susijusius su karių tarnybiniais nusižengimais ir nusikaltimais, saugojo Valstybės Prezidentą Antaną Smetoną ir svarbius užsienio šalių atstovus, užtikrino priešgaisrinę saugą, atlikdavo specifines užduotis, kurioms reikejjo specialaus pasirengimo, konvojavo karius, vykdẻ karinès vadovybės tarnybinius pavedimus. Be to, jie dalyvaudavo valstybinèse ir Kauno komendantūros šventèse ir minèjimuose, kurių metu buvo ugdomas karių tautiškumas, pilietiškumas ir religingumas. Visapusiškam karių lavinimui buvo išnaudojamas laisvalaikis, suteikiant kariams galimybę tobulèti tiek fiziškai, tiek kultūriškai.

5. Lietuvos Respublikos karinè teisètvarka pagrịsta ịstatymais ir kitais teisès aktais, kurių turinys susijęs su viešąja tvarka ir saugumu. Karo policijos mokyklos reikšmę teisètvarkos srityje galima vertinti vykdytų 
tarnybų ir veiklos aspektais. Karo policijos tarnyba buvo susijusi su nusižengimų ir nusikaltimų prevencija, ikiteisminio tyrimo veiksmų atlikimu, drausmès, tvarkos, saugumo užtikrinimu visuomenèje ir kariuomenėje, karinio turto apsauga ir drausmès taisyklių laikymusi. KPM kariai, baigę privalomąją karo tarnybą, buvo laukiami policijoje - viešojoje ir geležinkelių, - kuri šiose srityse turejo užtikrinti teisètvarką. Tačiau KPM dydis ir veiklos teritorija buvo riboti, neapèmè visos valstybès, todèl $1924 \mathrm{~m}$. karo policijos pagrindu prie Vidaus reikalų ministerijos buvo ịsteigtas specialus policijos padalinys - raitasis policijos rezervas, pajègos, galinčios padèti užtikrinti teisètvarką viešajame gyvenime.

Iteikta $2013 \mathrm{~m}$. birželio $14 \mathrm{~d}$. 


\title{
LA POLICE MILITAIRE DE L' ARMEE LITUANIENNE ENTRE 1919 ET 1940
}

\author{
Lina KASPARAITE்-BALAIŠE் \\ Musée de la guerre de Vytautas Magnus
}

Le 15 mars 1919, a été formée une compagnie de police militaire (externe) qui devait servir de pouvoir supplémentaire à la police publique, le 18 juillet, cette compagnie a été transformée en compagnie de Région. Puis le 1er décembre de la même année, une équipe de police militaire a été créée, puis après une reformation le 1er décembre 1920, il a été créé l'école de police sous l'autorité directe du poste de commandement militaire de Kaunas. Le 1er octobre 1924, l'école fut baptisée Ecole de police militaire. A ses débuts, le lieu d'implantation changeait régulièrement, c'est seulement en 1922 que l'école et les casernes ont déménagé définitivement dans le quartier de Žaliakalnis, jusqu’à la fermeture de lécole. Le personnel de l'école était composé d’officiers et de civils, qui avaient diverses fonctions et qui garantissaient le fonctionnement de l'Ecole de police militaire. Lordre intérieur de l'école était règlementé par l'agenda individuel et des règlements qui déterminaient la vie intérieure et l'organisation du service militaire fondée sur le respect des règles internes. La composition structurelle de l'Ecole de police militaire a changé deux fois, dû à une augmentation du nombre de soldats et l'élargissement des fonctions de l'école. Lécole devait former des policiers militaires professionnels suivant les lois du milieu militaire. Les soldats étaient alors choisis d'après des critères spécifiques. La formation des soldats était organisée selon des programmes spéciaux, basés sur la formation polyvalente des policiers militaires, en leur donnant non seulement des connaissances de théorie militaire mais aussi des enseignements pratiques et un enseignement général. Les soldats de l'école portaient l'uniforme commun aux soldats de l'infanterie avec un signe distinctif du service de la police militaire. Les troupes de soldats de l'école étaient organisées selon les exigences générales des soldats d'infanterie, seul le type de munition était spécialement déterminé pour effectuer le service de police militaire.

Le service des soldats de l'Ecole de police militaire était basé sur : la 
garde, la permanence en état d'alerte, les patrouilles, la sécurité, les actions de l'enquête, la réalisation des tâches spéciales et des diverses commissions. En organisant le service militaire avec l'action civique, la participation des soldats dans des évènements nationaux importants était garantie. Les soldats de lécole avaient le droit aux loisirs organisés sur la base de l'enseignement en utilisant le temps libre pour l'éducation polyvalente des soldats. L'Ecole de police militaire a fonctionné jusqu'au 11 novembre 1940, quand à la suite de l'occupation soviétique elle fut dissoute de la même manière que l'armée lituanienne.

\title{
LITHUANIAN ARMY MILITARY POLICE IN 1919-1940
}

\author{
Lina KASPARAITÉ-BALAIŠE் \\ Vytautas the Great War Museum
}

On 15 March 1919, a Military (outdoor) Militia Company was formed with the aim of being the auxiliary force to the public militia; on July 18, it was transformed into a County band of soldiers. On 1 December 1919, the Military (outdoor) Militia team was formed. This was followed by the establishment of the Military (outdoor) Militia School on 1 January 1920, which was directly subordinate to the Kaunas Military Commandant's Headquarters. On 1 October 1924, the school was renamed the Military Police School. Initially, the school did not have a permanent location but in 1922, the school and the barracks moved to barracks in Žaliakalnis neighbourhood, where they remained until the disestablishment of the school. The school staff teaching was composed of soldiers and civilians all of whom worked in different ways to ensure the proper functioning of the Military Police School. The internal life of the school was regulated by individual schedules and various instructions, which defined the internal life and organisation of military service based on compliance with the internal rules. The structure of the Military Police School had been changed twice due to increases in the number of soldiers and expanded functions. Professional military police officers were assigned as training officers, thus 
ensuring law and order among the soldiers. Soldiers were selected for service according to specific criteria. The training programme was based on the diverse training of military police officers by providing them not only with theoretical knowledge and practical skills, but also with general education. Soldiers of the military school wore infantry uniforms with the unique badge of the Military Police Service. The equipment of soldiers of the military school was assembled under the general requirements of infantry, whereas the armament was specifically established to carry out military police service.

During their time at the Military Police School soldiers engaged in a wide range of duties. Soldiers had: to be on guard, to be combat ready, to patrol, ensure security, carry out pre-trial actions, execute specific tasks and fulfil various service orders. The combination of military service with civil actions ensured the participation of soldiers in many significant public and other types of events. Soldiers of the military school had the right to leisure organised on the grounds of educational training using the time for comprehensive training of soldiers. The Military Police School functioned until 11 November 1940 when, due to the Soviet occupation, it was disbanded using common criteria for the dissolution of the Lithuanian Army. 